Prepared for Commander, Navy Region Southwest

Monitoring Avian Productivity and Survivorship (MAPS) 5-Year Summary, Naval Outlying Landing Field, Imperial Beach, Southwestern San Diego County, California, 2009-13

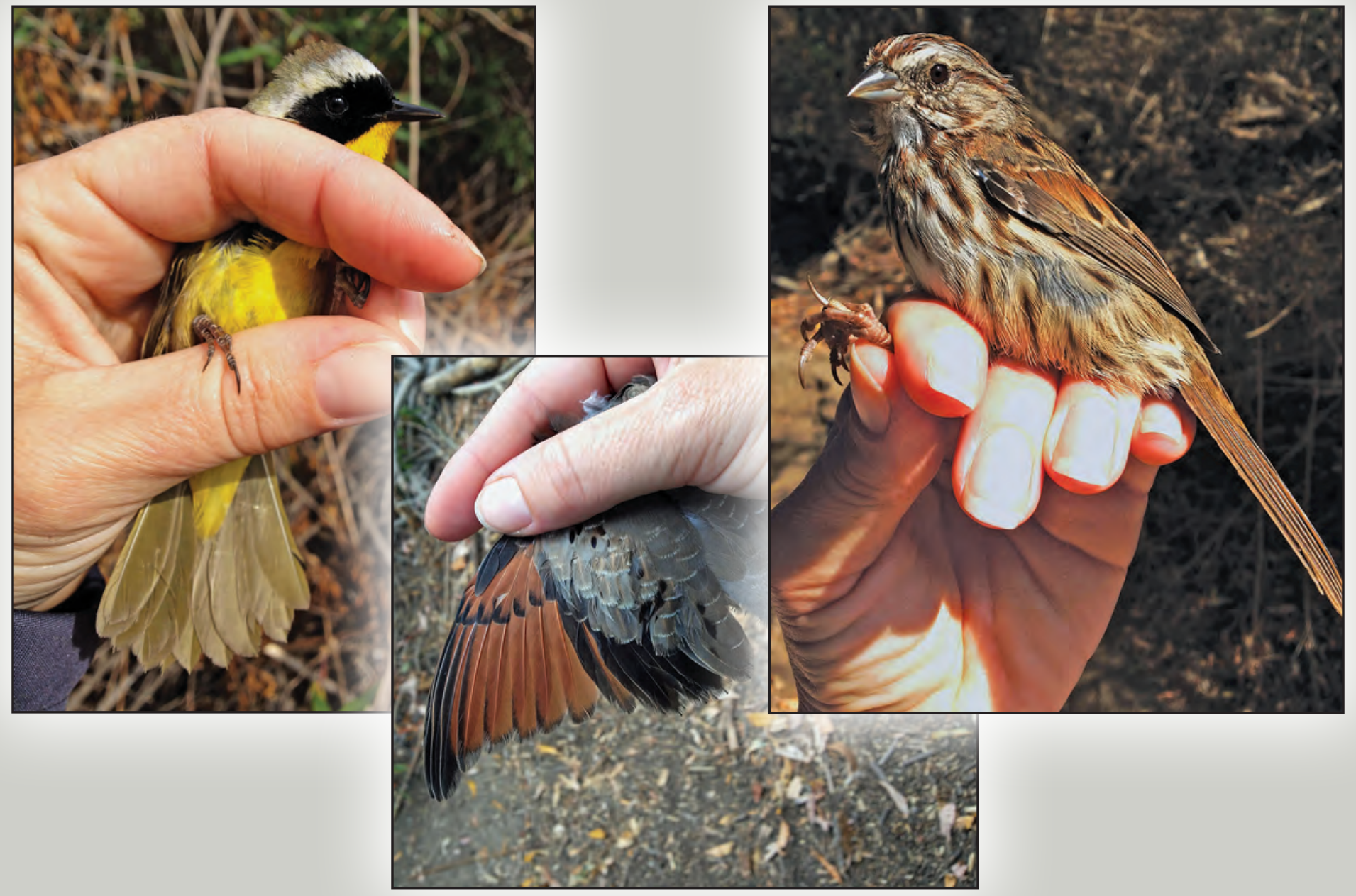

Open-File Report 2015-1035 
Cover: Cover photographs (from left to right; all taken at NOLF MAPS station by Melanie Madden): Common Yellowthroat (Geothlypis trichas) taken April 5, 2012; Common Ground-Dove (Columbina passerina) taken August 1, 2013; and Song Sparrow (Melospiza melodia) taken July 26, 2012. 


\section{Monitoring Avian Productivity and Survivorship (MAPS) 5-Year Summary, Naval Outlying Landing Field, Imperial Beach, Southwestern San Diego County, California, 2009-13}

By Suellen Lynn, Melanie Madden, Alex Houston, and Barbara E. Kus

Prepared for Commander, Navy Region Southwest

Open-File Report 2015-1035

U.S. Department of the Interior

U.S. Geological Survey 


\section{U.S. Department of the Interior \\ SALLY JEWELL, Secretary}

\section{U.S. Geological Survey \\ Suzette M. Kimball, Acting Director}

U.S. Geological Survey, Reston, Virginia: 2015

For more information on the USGS—-the Federal source for science about the Earth,

its natural and living resources, natural hazards, and the environment-visit

http://www.usgs.gov or call 1-888-ASK-USGS (1-888-275-8747)

For an overview of USGS information products, including maps, imagery, and publications, visit http://www.usgs.gov/pubprod

To order this and other USGS information products, visit http://store.usgs.gov

Any use of trade, firm, or product names is for descriptive purposes only and does not imply endorsement by the U.S. Government.

Although this information product, for the most part, is in the public domain, it also may contain copyrighted materials as noted in the text. Permission to reproduce copyrighted items must be secured from the copyright owner.

Suggested citation:

Lynn, Suellen, Madden, Melanie, Houston, Alex, and Kus, B.E., 2015, Monitoring avian productivity and survivorship (MAPS) 5-year summary, Naval Outlying Landing Field, Imperial Beach, southwestern San Diego County, California, 2009-13: U.S. Geological Survey Open-File Report 2015-1035, 58 p., http://dx.doi.org/10.3133/ofr20151035.

ISSN 2331-1258 (online) 


\section{Contents}

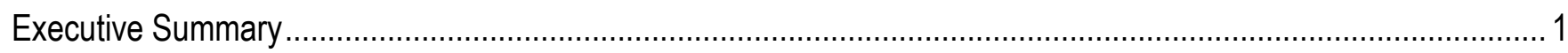

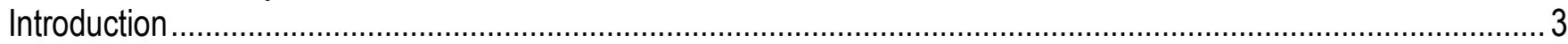

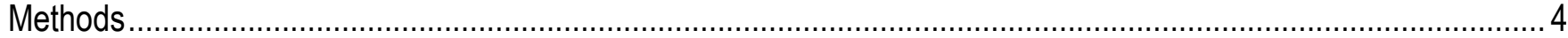

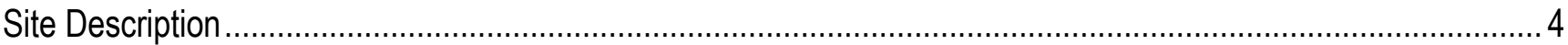

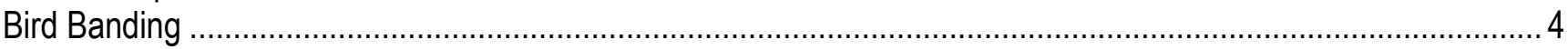

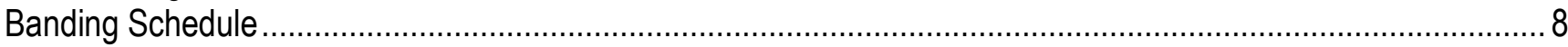

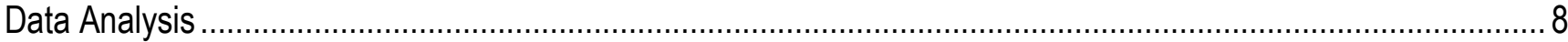

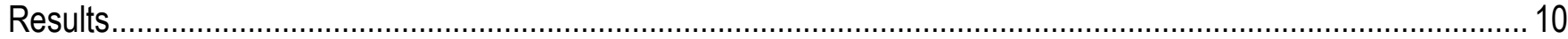

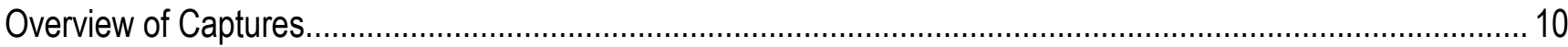

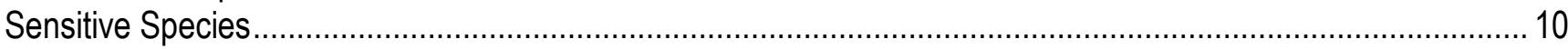

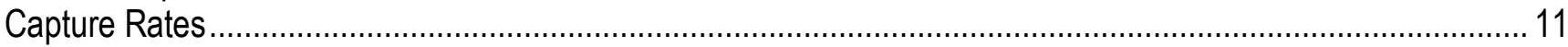

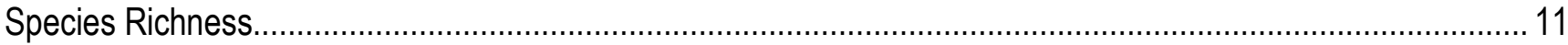

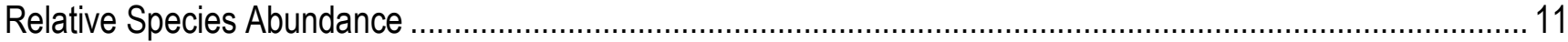

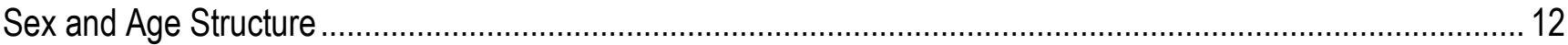

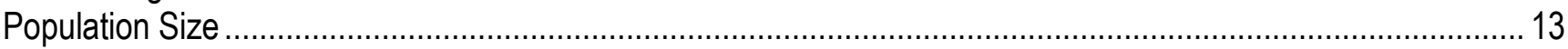

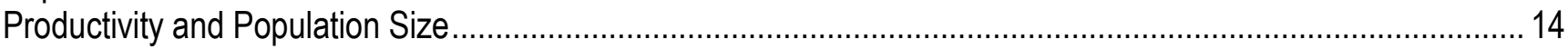

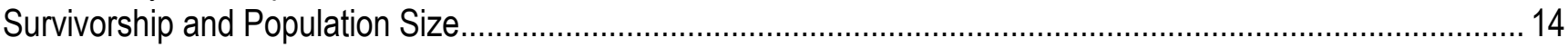

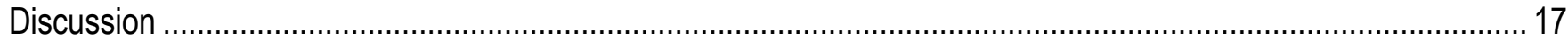

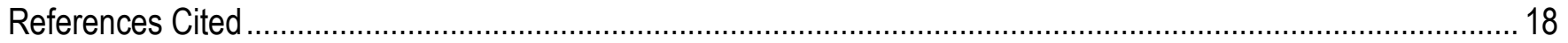

Appendix A. Alpha Codes, Common Names, and Scientific Names for Species Captured and Observed, Naval Outlying Landing Field, Imperial Beach, Southwestern San Diego County, California, 2009-13................... 20

Appendix B. Tables and Additional Figures, Naval Outlying Landing Field, Imperial Beach, Southwestern San Diego County, California, 2009-13.

\section{Figures}

Figure. 1. Location of the Monitoring Avian Productivity and Survivorship (MAPS) banding station, Naval Outlying Landing Field (NOLF), Imperial Beach, southwestern San Diego County, California.

Figure 2. Net locations at Monitoring Avian Productivity and Survivorship (MAPS) banding station, Naval Outlying Landing Field (NOLF), Imperial Beach, southwestern San Diego County, California

Figure 3. Adult population trends for four year-round resident bird species (Wrentit, Orange-crowned Warbler, Common Yellowthroat, and Song Sparrow) and two migratory bird species (Least Bell's Vireo and Yellow Breasted Chat) at Naval Outlying Landing Field, Imperial Beach, southwestern San Diego County, California, 2009-13.

Figure 4. Annual productivity of six bird species captured and precipitation measured for the associated bio-year (July 1-June 30) at Naval Outlying Landing Field, Imperial Beach, southwestern San Diego County, California, 2009-13

Figure 5. Adult annual survivorship (estimated by Program MARK) for (a) four year-round resident bird species (Wrentit, Orange-crowned Warbler, Common Yellowthroat, and Song Sparrow) and (b) two migratory bird species (Least Bell's Vireo and Yellow Breasted Chat) and precipitation measured for the associated bio-year (July 1-June 30) at Naval Outlying Landing Field, Imperial Beach, southwestern San Diego County,California, California, 2009-13. 


\section{Table}

Table 1. Global Positioning System locations of mist nets at Monitoring Avian Productivity and Survivorship banding station (MAPS), Naval Outlying Landing Field (NOLF), Imperial Beach, southwestern San Diego County, California.

\section{Conversion Factors}

International System of Units to Inch/Pound

\begin{tabular}{lcll}
\hline & Multiply & & To obtain \\
\hline & Length & & \\
\hline millimeter (mm) & 0.03937 & inch (in.) & \\
meter $(\mathrm{m})$ & 3.281 & foot (ft) & \\
kilometer $(\mathrm{km})$ & 0.6214 & mile (mi) \\
kilometer $(\mathrm{km})$ & 0.5400 & mile, nautical (nmi) & \\
meter $(\mathrm{m})$ & 1.094 & yard (yd) \\
\hline & Area & & \\
\hline hectare (ha) & 2.471 & acre \\
square hectometer $\left(\mathrm{hm}^{2}\right)$ & 2.471 & acre \\
\hline
\end{tabular}

\section{Datum}

Horizontal coordinate information is referenced to the World Geodetic System of 1984 (WGS84).

\section{Supplemental Information}

Note to USGS users: Use of hectare (ha) as an alternative name for square hectometer ( $\left.\mathrm{hm}^{2}\right)$ is restricted to the measurement of small land or water areas.

\section{Abbreviations}

AMEC $\quad$ AMEC Earth and Environmental, Inc.

DOD U.S. Department of Defense

DOD PIF Department of Defense Partners in Flight

IBP Institute for Bird Populations

MAPS Monitoring Avian Productivity and Survivorship

NASNI Naval Air Station North Island

NOLF Naval Outlying Landing Field

USFWS U.S. Fish and Wildlife Service 


\title{
Monitoring Avian Productivity and Survivorship (MAPS) 5-Year Summary, Naval Outlying Landing Field, Imperial Beach, Southwestern San Diego County, California, 2009-13
}

\author{
By Suellen Lynn, Melanie Madden, Alex Houston, and Barbara E. Kus
}

\section{Executive Summary}

During 2009-13, a Monitoring Avian Productivity and Survivorship (MAPS) banding station was operated at the Naval Outlying Landing Field (NOLF), Imperial Beach, in southwestern San Diego County, California. The station was established as part of a long-term monitoring program of Neotropical migratory bird populations on NOLF and helps Naval Base Coronado (NOLF is a component) meet the goals and objectives of Department of Defense Partners in Flight program and the Birds and Migratory Birds Management Strategies of the Naval Base Coronado Integrated Natural Resources Management Plan. The station was operated by AMEC Earth and Environmental, Inc., during the spring and summer of 2009-11. The U.S. Geological Survey operated the MAPS banding station in 2012 and 2013.

During 2009-13, we had 3,221 captures (including initial captures and recaptures) of a maximum of 2,682 individual captures ( $644 \pm 155$ captures per year). A count of individuals captured includes 2,464 newly banded birds and 218 birds were released unbanded (116 hummingbirds and 102 other birds that were intentionally released unbanded [game birds, etc.] or escaped before banding). Fifty-seven species were captured, of which 44 are considered Neotropical migratory species and 33 are considered to breed at the MAPS banding station. Bird capture rate averaged $84 \pm 10$ captures per 100 net-hours for all years (range 11-120 captures per 100 net-hours) and species richness per year averaged $35 \pm 7$. Bushtit (Psaltriparus minimus) was the most abundant species captured, followed by Song Sparrow (Melospiza melodia), Common Yellowthroat (Geothlypis trichas), and Orange-crowned Warbler (Oreothlypis celata). The average adult sex ratio across years was 55:45 male:female. Adults averaged $57.4 \pm 6.7$ percent of known age captures per year (range 49-64 percent) and juveniles averaged $42.6 \pm 6.7$ percent (range 36-51 percent). 
Twenty-two sensitive species were detected at NOLF (14 captured and 8 observed only). During 2009-13, we captured one State and federally endangered species, Least Bell's Vireo (Vireo bellii pusillus); one State endangered species, Willow Flycatcher (Empidonax traillii); and two State species of concern, Yellow-breasted Chat (Icteria virens) and Yellow Warbler (Setophaga petechia). One additional State species of concern, Northern Harrier (Circus cyaneus), was observed at the MAPS banding station, but not captured. Peregrine Falcon (Falco peregrinus) and White-tailed Kite (Elanus leucurus), State fully protected species, also were observed at the MAPS banding station. Three Federal conservation concern species-Allen's Hummingbird (Selasphorus sasin), Nuttall's Woodpecker (Picoides nuttallii), and Lawrence's Goldfinch (Spinus lawrencei) - also were captured, and two additional Federal conservation concern species - Long-billed Curlew (Numenius americanus) and Costa's Hummingbird (Calypte costae) - were observed only. An additional 10 species detected at NOLF ( 7 captured and 3 observed only) are considered bird species of conservation concern, including one of the most abundant species at the MAPS banding station-Wrentit (Chamaea fasciata). Sixteen of the sensitive species are considered Neotropical migratory species (10 captured and 6 observed only) and 9 breed at NOLF (7 captured and 2 observed only).

Local population trends varied among species and years. Overall, from 2009 to 2013, year-round residents Orange-crowned Warbler, Common Yellowthroat, and Song Sparrow increased, whereas year-round resident Wrentit decreased. Among migrants, the numbers of Least Bell's Vireo were stable, whereas Yellow-breasted Chat decreased.

Annual productivity (number of young per adult) was calculated for the six breeding species constituting 5 or more percent of the individual captures in 1 or more years (Bushtit, Song Sparrow, Common Yellowthroat, Orange-crowned Warbler, Wrentit, and Yellow-breasted Chat). Productivity for most of these species were lowest in 2012, whereas the year of highest productivity varied, but mostly occurred in 2009 or 2010. Song Sparrow demonstrated the highest productivity among species, with about two juveniles per adult captured during 2009-13. Average productivity was lowest for Yellow-breasted Chat ( 0.4 juveniles per adult), largely a result of 2 years (2011 and 2012) without any juvenile captures. We did not find a significant relationship between productivity and the observed population size in the subsequent year for any species, nor did we find an association between productivity and precipitation for the current bio-year.

Six species were analyzed for survivorship - Common Yellowthroat, Least Bell's Vireo, Orange-crowned Warbler, Song Sparrow, Wrentit, and Yellow-breasted Chat. Although survivorship varied across species and years, there was no obvious relationship between adult survivorship and observed population size for any species except Wrentit, for which the relationship was positive. We also did not find an association between adult survivorship and precipitation at the MAPS banding station. Additional years of data will be required to generate sample sizes adequate for more rigorous analyses of survivorship and productivity as predictors of population growth.

Differences in population trends between year-round resident species and Neotropical migratory species may be attributed to the extra pressures incurred by migration and wintering in areas that likely are subject to stronger anthropogenic stresses than in the protected area surrounding NOLF. 


\section{Introduction}

Monitoring Avian Productivity and Survivorship (MAPS) is an international monitoring program coordinated by the Institute for Bird Populations (IBP), which uses bird capture and banding data to compile basic demographic parameters of resident and migratory species, many of which are imperiled regionally and even globally. Age- and sex-specific data on annual survival, reproduction, and recruitment can be gathered and compared across stations to identify population trends for species of interest and can be used to identify proximate factors responsible for trends, particularly negative trends. In turn, information obtained from long-term monitoring of bird populations can be used to guide management activities intended to maintain or reestablish viable populations throughout the ranges of species.

A MAPS banding station was established in 2009 at the Naval Outlying Landing Field (NOLF), Imperial Beach, in southwestern San Diego County, California (Myers, 2011). The station was established as part of a long-term monitoring program of Neotropical migratory bird populations on NOLF and helps Naval Base Coronado meet the goals and objectives of the Department of Defense Partners in Flight (DOD PIF) program and the Birds and Migratory Birds Management Strategies of the Naval Base Coronado Integrated Natural Resources Management Plan (U.S. Navy, 2014). This project also supports the Memorandum of Understanding between the DOD and U.S. Fish and Wildlife Service (USFWS) to promote the conservation of migratory birds by implementing an existing, nationwide bird monitoring program at NOLF. The station is being operated in a manner consistent with other banding stations participating in an effort to monitor birds worldwide. The station was operated by AMEC Earth and Environmental, Inc. (AMEC) from 2009 to 2011, and by the U.S. Geological Survey in 2012 and 2013.

This project was implemented for 5 years, the minimum number of consecutive years necessary to obtain productivity indices and survivorship estimates according to the MAPS program (DeSante and others, 2011). There are four objectives for this project: (1) to estimate population sizes and trends of various Neotropical migratory bird species, (2) to estimate demographic and survivorship parameters for Neotropical migratory bird species, (3) to estimate annual productivity for these species, and (4) to augment existing distributional information for sensitive avian species.

This project was funded by Commander Navy Region Southwest. 


\section{Methods}

\section{Site Description}

NOLF encompasses about 509 ha in southwestern San Diego County, including 112 ha of roads and developed areas. NOLF is $16 \mathrm{~km}$ south of Naval Air Station North Island (NASNI) and $2.4 \mathrm{~km}$ north of the United States-Mexico border. Navy lands extend into the Tijuana River National Estuarine Research Reserve, co-managed by USFWS, the National Oceanic and Atmospheric Administration, and California State Parks (fig. 1). Parts of NOLF are managed cooperatively with the Tijuana Slough National Wildlife Refuge under a memorandum of understanding between NASNI and the USFWS relating to the protection of natural resources. Vegetation at the station is a mix of riparian willow (Salix spp.) forest dominated by arroyo willow (Salix lasiolepis), red willow (Salix laevigata), black willow (Salix gooddingii), and mule fat (Baccharis salicifolia), and riparian scrub dominated by mule fat and sandbar willow (Salix exigua).

\section{Bird Banding}

Bird banding at NOLF followed standardized MAPS protocol (DeSante and others, 1993). Ten mist nets, placed a minimum of $65 \mathrm{~m}$ apart, were erected in fixed locations selected for their potential to capture birds moving through vegetation (table 1, fig. 2). Mist nets were made of $30 \mathrm{~mm}$ mesh black nylon and were $12 \mathrm{~m}$ long by $2.6 \mathrm{~m}$ high with four trammels ("pockets") running the length of the net. Nets were suspended from vertical aluminum poles anchored by permanent rebar stakes and covered a vertical area ranging from about 0.25 to $2.5 \mathrm{~m}$ above-ground. Nets were opened within 30 minutes of dawn and remained open for 6 hours, typically until between 1200 and 1300 PDT. Nets were not operated during inclement weather such as strong wind, rain, extreme heat, or cold. 


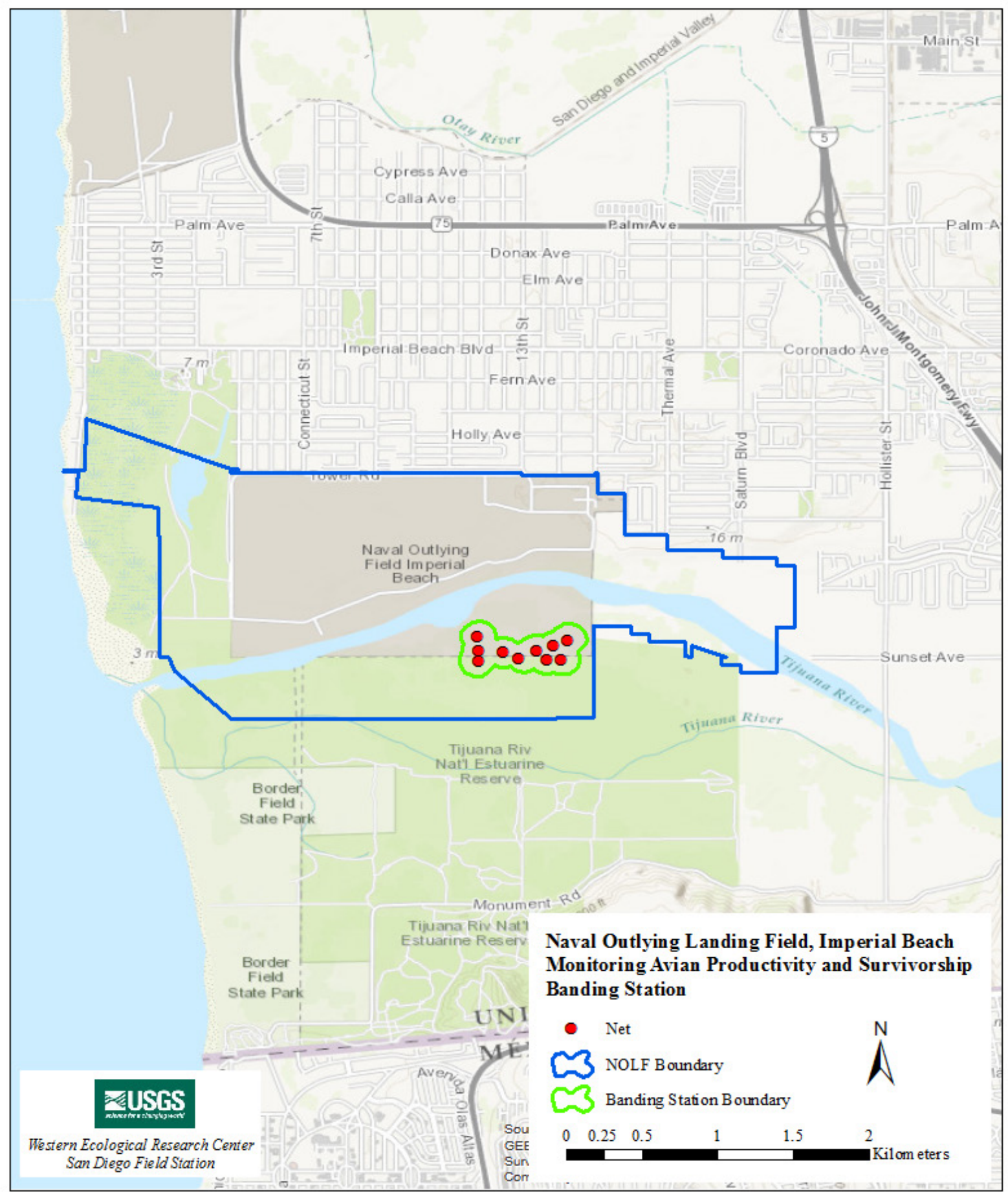

Figure. 1. Location of the Monitoring Avian Productivity and Survivorship (MAPS) banding station, Naval Outlying Landing Field (NOLF), Imperial Beach, southwestern San Diego County, California. 


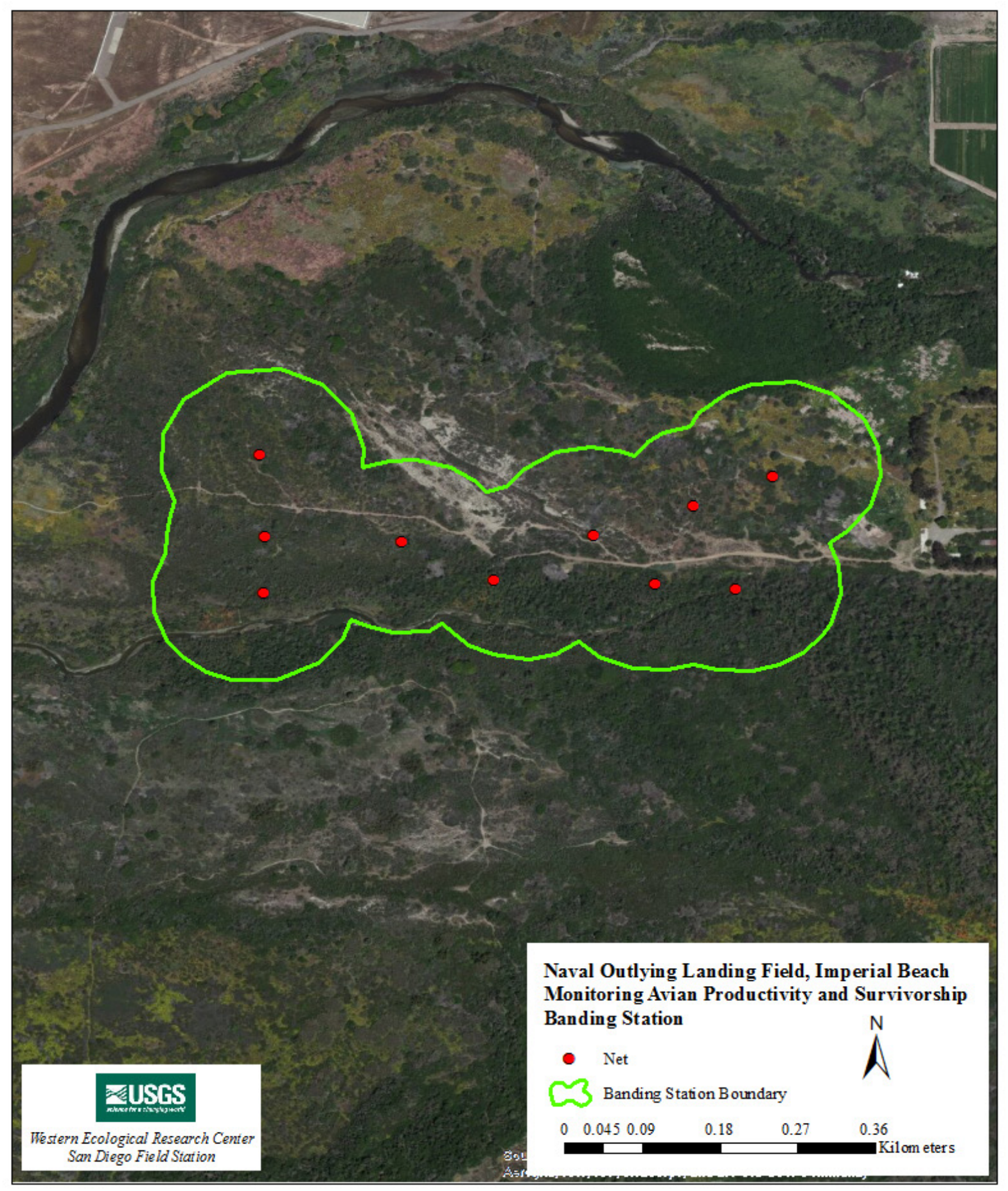

Figure 2. Net locations at Monitoring Avian Productivity and Survivorship (MAPS) banding station, Naval Outlying Landing Field (NOLF), Imperial Beach, southwestern San Diego County, California. 
Table 1. Global Positioning System locations of mist nets at Monitoring Avian Productivity and Survivorship banding station (MAPS), Naval Outlying Landing Field (NOLF), Imperial Beach, southwestern San Diego County, California.

[Coordinates are in World Geodetic System of 1984 (WGS 84)]

\begin{tabular}{ccl}
\hline $\begin{array}{c}\text { Net number } \\
\text { (see fig. 2) }\end{array}$ & Longitude & Latitude \\
\hline 1 & -117.10307 & 32.55817 \\
2 & -117.10341 & 32.55808 \\
3 & -117.10425 & 32.55813 \\
4 & -117.10594 & 32.55818 \\
5 & -117.10689 & 32.55857 \\
6 & -117.10833 & 32.55804 \\
7 & -117.10831 & 32.55862 \\
8 & -117.10837 & 32.55948 \\
9 & -117.10489 & 32.55864 \\
10 & -117.10386 & 32.55895 \\
\hline
\end{tabular}

Nets were checked every 30-40 minutes by operators working circuits. Hummingbirds, game birds, and other non-passerines were not banded (AMEC banded raptors from 2009 to 2011) but were identified by species, age, and sex when possible and released at the capture site. Birds were removed from nets, held in cloth bags labeled with the net number, and taken to a central processing location where they were banded with numbered Federal aluminum bands. Least Bell's Vireo (Vireo bellii pusillus) captured at this MAPS banding station were colorbanded with a unique color combination for visual identification as part of a separate survey effort for this species. Data recorded for each individual captured included age, sex, skull ossification, breeding condition, weight, wing chord, fat deposition, feather wear, and molt status, using Pyle (1997) as a reference. Birds that already had bands when captured also were processed and their band numbers were recorded. These birds were considered "recaptures." We recorded only the initial capture of a bird on each banding day (we did not record same-day recaptures). A bird only was considered a recapture on each unique day it was captured after its original banding. Birds were held for 5-45 minutes depending on the number of birds captured during one net run. After processing, juveniles, brooding females, and resident birds from the more distant nets were released near the net in which they had been captured, whereas all other birds were released at the central processing location. A list of all birds observed, including species not captured, and their possible breeding status at the MAPS banding station, was kept for each banding day. A minimum of five personnel typically operated the MAPS banding station. 


\section{Banding Schedule}

Following standard MAPS protocol, the MAPS banding station was operated 1 day during every 10-day netting period during the MAPS season (May 1-August 8). In 2012 and 2013, the MAPS banding station was operated during three additional 10-day netting periods prior to the start of the MAPS season (April 1-30) for a total of 13 banding days. These netting periods were added to accommodate earlier breeding species such as Orange-crowned Warbler (Oreothlypis celata) and for comparisons with other MAPS banding stations in San Diego County, which begin operation in April (Allen and Kus, 2014; Madden and Kus, 2014; Madden and others, 2014).

\section{Data Analysis}

All banding data were entered into MAPSPROG, the IBP data entry program, for verification and error checking, which also included cross-checking against data from previous years. Finalized MAPSPROG data were submitted to IBP and Naval Base Coronado, and analyzed. MAPSPROG data from 2009 through 2011 were obtained from IBP and included in the analyses. This report presents a summary of banding data from 2009 through 2013.

Bird captures were quantified by species, age, sex, and number of captures for each year. The total number of captures (including newly banded birds, captured but unbanded birds, and all recaptures) was used to create a captured species list and a total count of captures per species for the MAPS banding station. We intentionally did not band hummingbirds because they are difficult to band and recapture and would require a concentrated effort beyond the scope of a MAPS banding station. We included hummingbirds in the total count of captures and the captured species list, but did not include them in further analyses because we could not determine individual identity, and, therefore, could not accurately calculate abundance, productivity, or survivorship. For analyses, the population size for each species was the total number of individuals captured, including only newly banded birds and first-time recaptures of birds originally banded in previous years.

Capture rates of each species were calculated for each year by dividing the total number of individuals captured by the total number of hours nets were open at the MAPS banding station (net-hours), and multiplying this number by 100. Captures per 100 net-hours is a standard unit of measurement used for bird banding analyses. Calculating capture rates in this manner allowed us to account for the discrepancy in the number of banding days each year (10 banding days in 2009-11, 13 banding days in 2012-13) and to make between-year comparisons.

We calculated species richness (number of species captured at the MAPS banding station), relative species abundance (the proportion of all individuals represented by a particular species), seasonal and annual variation in individual captures, sex and age ratios (to determine the structure and overall health of the population), productivity (a reproductive index represented by the number of juveniles captured divided by the number of adults captured), adult survivorship (based on analysis of recapture rates using Program MARK, as described later in this section), and population trends. 
Age structure and seasonal and annual variation in individual captures were examined for seven species that constituted 5 percent or more of individual captures in 1 year or more. Bushtit (Psaltriparus minimus), Song Sparrow (Melospiza melodia), Common Yellowthroat (Geothlypis trichas), and Orange-crowned Warbler constituted more than 5 percent of individual captures in all years. Wrentit (Chamaea fasciata) constituted 5 percent or more of captures in 2009-10. Wilson's Warbler (Cardellina pusilla) constituted 5 percent or more of captures in 2010-11, but only wintered at or migrated through the MAPS banding station and, therefore, was only used for analyses of seasonal and annual variation. Yellow-breasted Chat (Icteria virens) constituted 5 percent or more of the captures in 2009. We also analyzed individual captures of Least Bell's Vireo, which constituted $0.7-4.1$ percent of the captures each year, to examine the status of this Federal and State protected species at NOLF.

Annual productivity and survivorship were calculated for six species selected based on criteria presented by IBP for survivorship analyses. These criteria include (1) at least 2.5 individuals of the species captured per year, with a minimum of 30 year-unique captures; (2) at least two recaptures; and (3) survival and recapture probability not equal to 0 or 1 . An index of productivity was calculated by dividing the number of juvenile (hatching-year) individuals captured each year by the number of adults (after hatching-year) captured each year. This index was used to calculate expected population size for the following year where expected population size in year $x_{x}=$ population size in year $x_{x-1}+\left(\right.$ population size in year $_{x-1} \times$ productivity in year $\left._{x-1}\right)$ (Kus and Kisner, 2003). Expected population size was compared to observed population size to evaluate the contribution of productivity to population growth in each species.

We analyzed annual survivorship of adults for the six species by creating encounter histories for each year from 2009 to 2013 , coding capture or recapture as " 1 " and no capture or recapture as " 0 ". Birds that originally were banded as young (during their hatching year) were included in analyses as adults in subsequent years. Encounter histories for each species were compiled and analyzed in Program MARK to obtain annual survivorship estimates. To determine and compare the contribution of adult survival to annual population change in the six species, expected and observed population sizes were compared for each year, where expected population

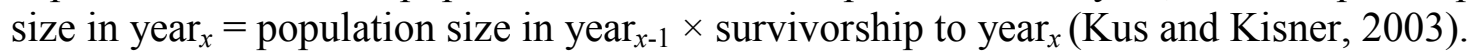

Annual precipitation was calculated for each bio-year (July 1-June 30) during which the MAPS banding station was operated using historical data compiled by Weather Underground (The Weather Channel, LLC, 2014). Annual precipitation then was correlated for the current bioyear (that is, the year ending June 30 during the MAPS season) with annual productivity for each of the six species. For resident species, survivorship was correlated with precipitation during the concurrent bio-year. For migrant species, survivorship was correlated with precipitation during the previous bio-year to account for the fact that migrants are absent from the MAPS banding station from September to March of the current bio-year and, thus, their survivorship likely is more influenced by precipitation at the MAPS banding station during the previous bio-year than the current bio-year. 
Species were compared according to their migratory status in analyses of age structure, seasonal and annual variation in capture rate, productivity, and survivorship. Neotropical migratory species were defined as those covered under the Neotropical Migratory Bird Conservation Act of 2000 (U.S. Fish and Wildlife Service, 2013; appendix A, tables A1 and A2); however, some species considered Neotropical migratory birds under the Act are known to be year-round residents in southwestern San Diego County and, therefore were considered resident species for this analysis. Year-round resident species in this analysis included Bushtit, Song Sparrow, Common Yellowthroat, Orange-crowned Warbler, and Wrentit. Of these five species, only Bushtit and Wrentit are not considered Neotropical migrants. Species known to winter outside southwestern San Diego County were considered migratory. Migratory species were Wilson's Warbler, Yellow-breasted Chat, and Least Bell's Vireo.

\section{Results}

\section{Overview of Captures}

In 3,347 net-hours (669 \pm 95 net-hours per year) during the 2009-13 MAPS seasons, we had a total of 3,221 captures ( $644 \pm 155$ captures per year; appendix B, table B1). Of the 3,221 total captures, 2,464 were newly banded of which 218 were individuals recaptured from previous years for a total of 2,682 captures (536 \pm 117 individual captures per year). An additional 218 birds were released unbanded (116 hummingbirds and 102 other birds that were intentionally released unbanded [game birds, etc.] or escaped before banding) for a maximum of 2,682 individual captures. We captured 57 species, of which 44 were Neotropical migratory species, and 33 were considered to breed at the MAPS banding station (appendix A, table A1; appendix $\mathrm{B}$, table B1; unidentified species not included in species total).

Two notable Neotropical migratory species were recaptured in 2013. A Golden-crowned Sparrow (Zonotrichia atricapilla) and a White-crowned Sparrow (Zonotrichia leucophrys), both originally banded in April 2012, were recaptured in April 2013. It is unknown whether these birds migrated through or wintered at NOLF in both years. These were the only non-breeding birds that were banded and recaptured in a subsequent year.

\section{Sensitive Species}

Twenty-two sensitive species were detected at NOLF (14 captured and 8 observed only) (appendix A, tables A1 and A2). We captured one State and federally endangered species, Least Bell's Vireo (Vireo bellii pusillus), one State endangered species, Willow Flycatcher (Empidonax traillii), and two State species of concern, Yellow-breasted Chat (Icteria virens), and Yellow Warbler (Setophaga petechia) (appendix A, table A1; California Department of Fish and Game, 2011; California Department of Fish and Wildlife, 2013; U.S. Fish and Wildlife Service, 2014). One additional State species of concern, Northern Harrier (Circus cyaneus), was observed at the MAPS banding station, but was not captured (appendix A, table A2; California Department of Fish and Game, 2011). Peregrine Falcon (Falco peregrinus) and White-tailed Kite (Elanus leucurus), State fully protected species, also were observed at the MAPS banding station (California Department of Fish and Wildlife, 2013, 2014). Three Federal conservation concern species-Allen's Hummingbird (Selasphorus sasin), Nuttall's Woodpecker (Picoides nuttallii), and Lawrence's Goldfinch (Spinus lawrencei) - also were captured. Two additional federal conservation concern species_-Long-billed Curlew (Numenius americanus) and Costa's 
Hummingbird (Calypte costae) - were observed only (appendix A, tables A1 and A2; U.S. Fish and Wildlife Service, 2008). An additional 10 species detected at NOLF (7 captured and 3 observed only) are considered bird species of conservation concern, including one of the most abundant species at the MAPS banding station: Wrentit (appendix A, tables A1 and A2; Partners in Flight Science Committee, 2012). Nine of the sensitive species breed at NOLF (seven captured and two observed only). Sixteen of the sensitive species are considered Neotropical migratory species (10 captured and 6 observed only; U.S. Fish and Wildlife Service, 2013).

Forty-seven Least Bell's Vireo were captured and newly banded during 2009-13. Four of these were recaptured in subsequent years (seven total recaptures; appendix B, table B13). Of the 47 newly banded vireos, 44 were given unique color band combinations and 3 were banded with a single numbered metal band.

\section{Capture Rates}

Overall capture rates by MAPS period averaged $84 \pm 10$ captures per 100 net-hours for all years combined (range 11-120 captures per 100 net-hours; (appendix B, table B2). Capture rates by year ranged from 71-95 captures per 100 net-hours with 2010, 2012, and 2013 being the most productive years.

\section{Species Richness}

The number of species captured ranged from 28 to 43 per year (appendix B, tables B3B7). Species richness among captures was consistently highest in May, although in 2009, species richness peaked in early June. Overall species richness averaged $35 \pm 7$ per year.

\section{Relative Species Abundance}

Bushtit was the most abundant species, at 502 individual captures and averaging $15 \pm 2$ individual captures per 100 net-hours per year (appendix B, figs. B1 a-e and tables B3-B7). The second most abundant species was Song Sparrow with 425 individuals ( $13 \pm 2$ individual captures per 100 net-hours per year). Common Yellowthroat was the third most abundant species with 372 individuals ( $11 \pm 3$ individual captures per 100 net-hours per year). Orange-crowned Warbler was the fourth most abundant species with 320 individuals $(9 \pm 3$ individual captures per 100 net-hours per year). Each of the four species accounted for more than 5 percent of the individuals captured annually during 2009-13 and together accounted for 58 percent of all individuals captured during 2009-13. Additional species that accounted for 5 percent or more of the individuals captured in 1 year or more included Wrentit (2009 and 2010), Wilson's Warbler (2010 and 2011), and Yellow-breasted Chat (2009). Anna's Hummingbird constituted 5 percent or more of the captures in 2013 but was not included in further analyses because we could not distinguish between individual captures.

Seasonal and annual variation in individual captures varied for each of these seven species (appendix B, figs. B2a-g). Bushtit had two identifiable peaks in captures per year, one in May and one in late June to early July (appendix B, fig. B2a). Peaks in Song Sparrow captures varied annually, although the largest annual peak in captures occurred between late May and mid-June across all years (appendix B, fig. B2b). For Common Yellowthroat, the largest peak typically occurred in early to mid-June, although the peak was later (early July) in 2010 and there was no peak at all in 2011. Notably for Common Yellowthroat, in the years when banding 
began in April, about 25 percent of all captures occurred prior to the start of the MAPS season (May 1) (appendix B, fig. B2c). Orange-crowned Warbler captures peaked by the end of May in all years (appendix B, fig. B2d). In 2012 and 2013, the peaks in Orange-crowned Warbler captures occurred prior to the start of the MAPS season, with 41 percent of the captures in 2012 and 58 percent of the captures in 2013 occurring in April. Wrentit captures were relatively small in number compared to the top four species (Bushtit, Song Sparrow, Common Yellowthroat, and Orange-crowned Warbler). However, peaks in Wrentit captures occurred in late May through early July and varied by year (appendix B, fig. B2e). The number of Yellow-breasted Chat captures also was relatively low each year compared to the top four species. In 2011, we did not capture any juvenile Yellow-breasted Chats, and, after the beginning of June, we did not capture any Yellow-breasted Chats (appendix B, fig. B2f). The peaks in captures of Wilson's Warbler, a non-breeding migratory species for the MAPS banding station, usually occurred in early to midMay, and the latest capture of this species was in early June (June 3, 2011; appendix B, fig. B2g).

\section{Sex and Age Structure}

The overall sex ratio of known-sex adult captures was slightly skewed towards males for all species combined from 2009 to 2013 (55:45 male:female for 2009-13, ranging from 49:51 to 61:39) (appendix B, tables B8-B12). Adults averaged $57.4 \pm 6.7$ percent of known age captures per year (range 49-64 percent) and juveniles averaged $42.6 \pm 6.7$ percent (range 36-51 percent). During most years, the adult capture rate was less than the 5-year average (46.9 \pm 7.4 captures per 100 net-hours). This average was driven primarily by the high capture rate in 2012 - the adult capture rate increased 35 percent between 2011 and 2012 (42.5-57.5 captures per 100 net-hours), followed by a 15 percent decrease between 2012 and 2013 (57.5-48.7 captures per 100 nethours). During most years, the juvenile capture rate was near or less than the 5-year average ( $33.7 \pm 6.4$ captures per 100 net-hours). The juvenile capture rate increased 24 percent between 2009 and 2010, decreased 40 percent between 2010 and 2011, and then increased 23 percent between 2011 and 2012. Juveniles of 29 species were captured between 2009 and 2013 (20 23 per year). The four most abundant juvenile species captured (Bushtit, Common Yellowthroat, Orange-crowned Warbler, and Song Sparrow) contributed 76 percent of the total number of juveniles captured between 2009 and 2013. The highest proportions of juvenile captures were Common Yellowthroats in 2009, Bushtits in 2010 and 2012, and Song Sparrows in 2011 and 2013.

The age structure of captures varied by year and by species for the six breeding species that constituted 5 percent or more of the captures during 1 year or more (appendix B, figs. B3af). More juveniles than adults were captured every year for Song Sparrow (fig. B3e). In contrast, more adults than juveniles were captured every year for Wrentit (fig. B3b) and Yellow-breasted Chat (fig. B3f). There was more variability in the other species, with Bushtit (fig. B3a) having more juveniles than adults in 2010, 2012 and 2013, and Orange-crowned Warbler (fig. B3c) and Common Yellowthroat (fig. B3d) having more juveniles than adults in 2009 and 2010. Out of the most abundant breeding species, Yellow-breasted Chat (fig. B3f) had the least number of juveniles overall, with no juveniles captured in 2011 and 2012, and more than twice as many adults than juveniles captured in 2010 and 2013. 


\section{Population Size}

Local population size, as measured by the number of adult individuals captured per 100 net-hours, increased for three year-round resident species and decreased for one year-round resident species from 2009 to 2013 (fig. 3). The Orange-crowned Warbler population was relatively stable from 2009 to 2011, then doubled from 2011 to 2012, and increased again from 2012 to 2013. The Song Sparrow population increased steadily from 2009 through 2013, although not as dramatically as the Orange-crowned Warbler population. The Common Yellowthroat population was relatively stable from 2009 to 2011, doubled from 2011 to 2012, and then decreased from 2012 to 2013. The Wrentit population decreased threefold from 2009 to 2013.

Populations of the two migrant bird species remained stable or decreased from 2009 to 2013 (fig. 3). The Least Bell's Vireo population remained stable from 2009 to 2013, and the Yellow-breasted Chat population decreased from 2009 to 2013.

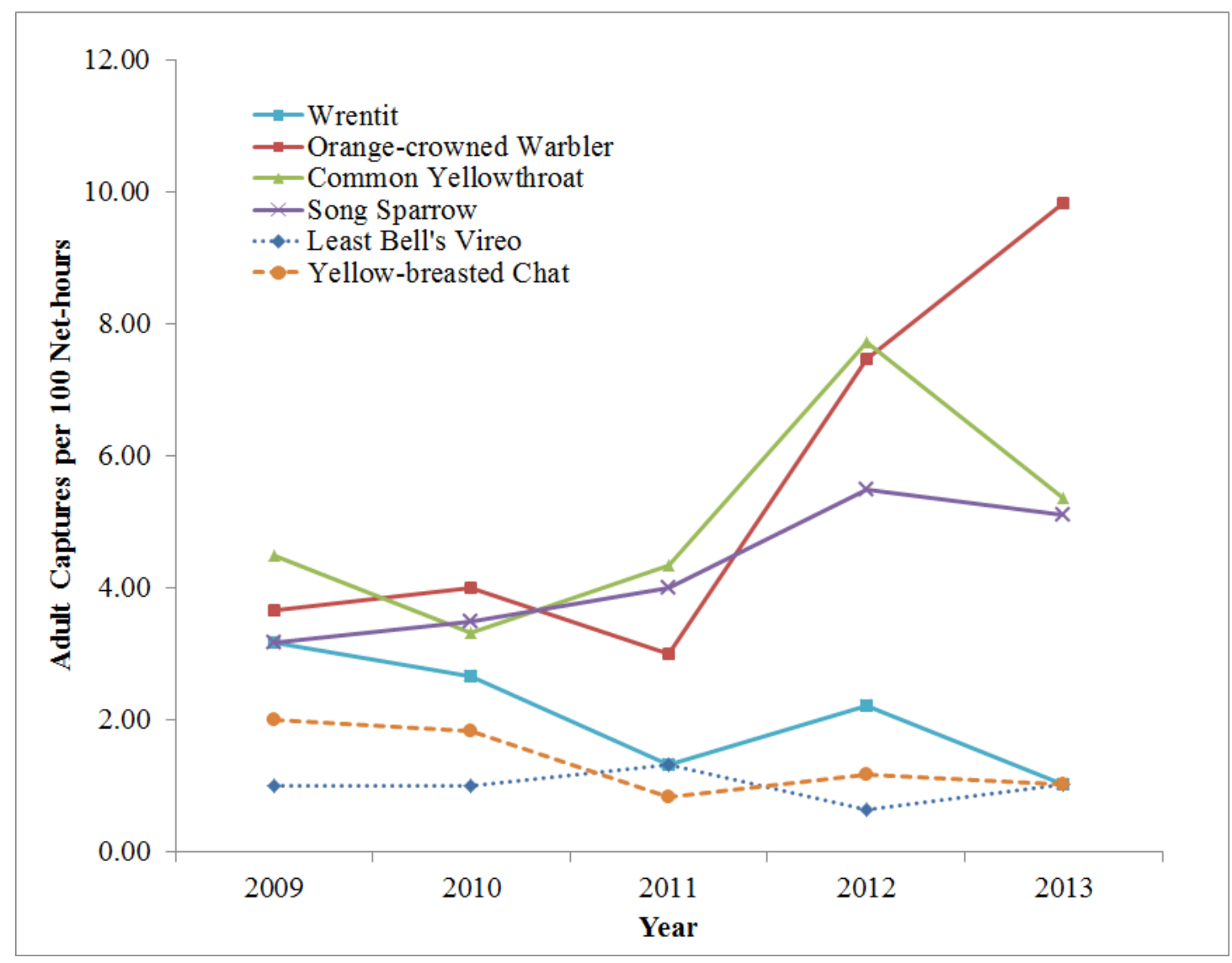

Figure 3. Adult population trends for four year-round resident bird species (Wrentit, Orange-crowned Warbler, Common Yellowthroat, and Song Sparrow) and two migratory bird species (Least Bell's Vireo and Yellow Breasted Chat) at Naval Outlying Landing Field, Imperial Beach, southwestern San Diego County, California, 2009-13. See appendix A for common and scientific names. 


\section{Productivity and Population Size}

Annual productivity generally was low for most species in 2011 and 2012, and generally high in 2010. Song Sparrow had the highest overall productivity, followed by Common Yellowthroat (fig. 4). Yellow-breasted Chat had the lowest overall productivity, with no juvenile captures in 2011 and 2012. Productivity was not significantly related to precipitation during the concurrent bio-year for any species (Orange-crowned Warbler $P=0.94$, Common Yellowthroat $P=0.60$, Song Sparrow $P=0.36$, Wrentit $P=0.31$, Yellow-breasted Chat $P=0.24$, Least Bell's Vireo $P=0.61)$.

Productivity was not a significant predictor of observed population size for any of the resident or migrant species (appendix B, fig. B4). However, for three species (Song Sparrow, Wrentit, and Yellow-breasted Chat), there appeared to be a trend toward population growth following years of high productivity, which may become more clear with additional years of data.

\section{Survivorship and Population Size}

Adult survivorship for year-round resident and migrant bird species varied among species and years from 2009 through 2013 (fig. 5). Adult survivorship was a significant predictor of population size for Wrentit (fig. B5a), but not for the remaining five species, although there was a trend toward a positive relationship for Song Sparrow, Common Yellowthroat, and Orangecrowned Warbler that may become more clear with additional years of data (figs. B5b, B5c). Adult survivorship by itself was a poor predictor of Least Bell's Vireo population size (fig. B5c). We found no significant association between adult survivorship and annual precipitation (Song Sparrow $P=0.43$, Wrentit $P=0.86$, Common Yellowthroat $P=0.53$, Orange-crowned Warbler $P=0.32$, Least Bell's Vireo $P=0.26$, Yellow-breasted Chat $P=0.35$ ). 


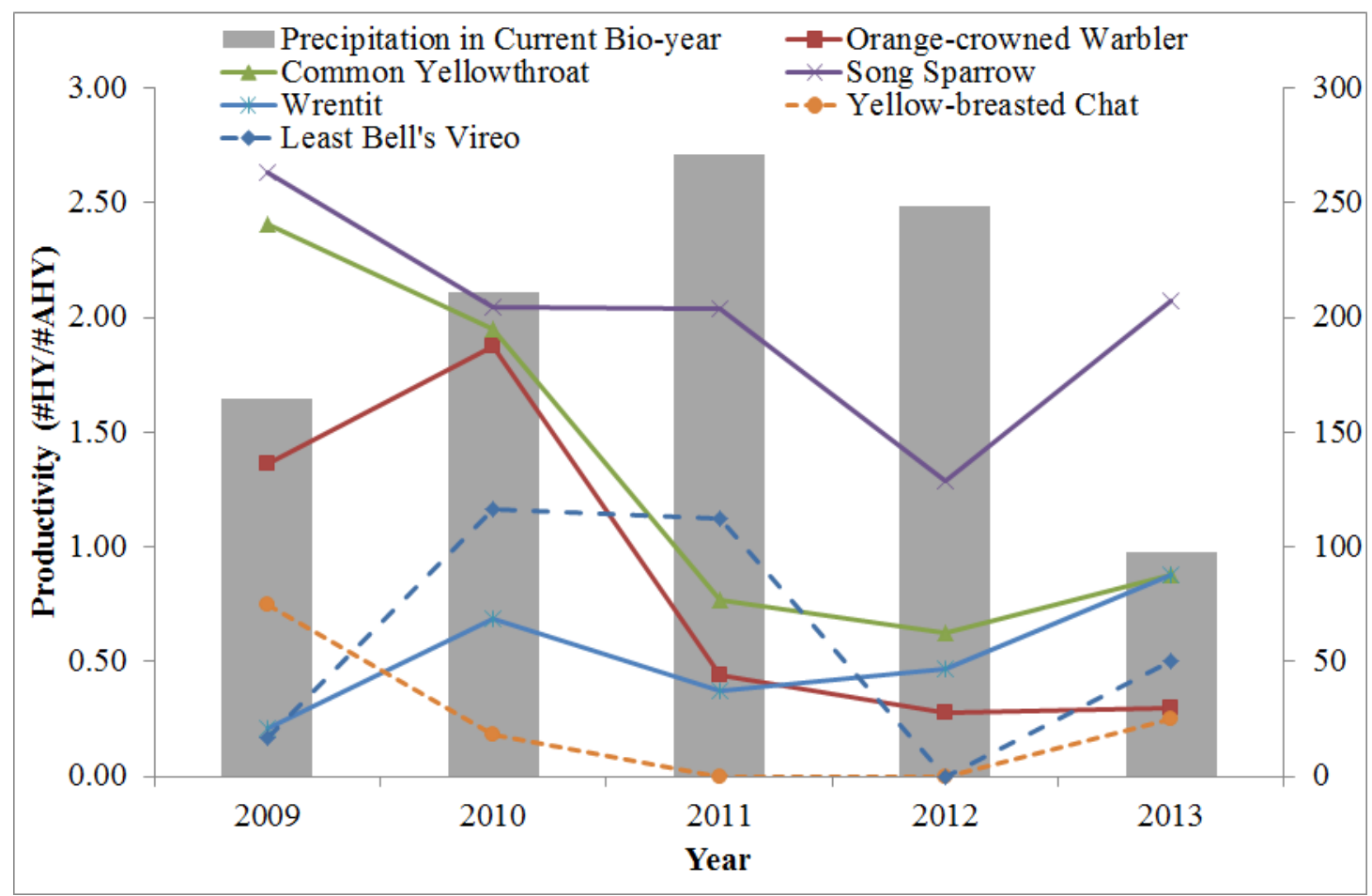

Figure 4. Annual productivity of six bird species captured and precipitation measured for the associated bio-year (July 1-June 30) at Naval Outlying Landing Field, Imperial Beach, southwestern San Diego County, California, 2009-13. Productivity is calculated as the number of juveniles (HY=hatching-year) divided by the number of adults ( $\mathrm{AHY}=$ after hatching-year). $\mathrm{A}$ solid line represents a year-round resident species (including species considered Neotropical migratory species under the Neotropical Migratory Bird Conservation Act of 2000; appendix A, table A1), and a dashed line represents a migratory species that was not a year-round resident. 

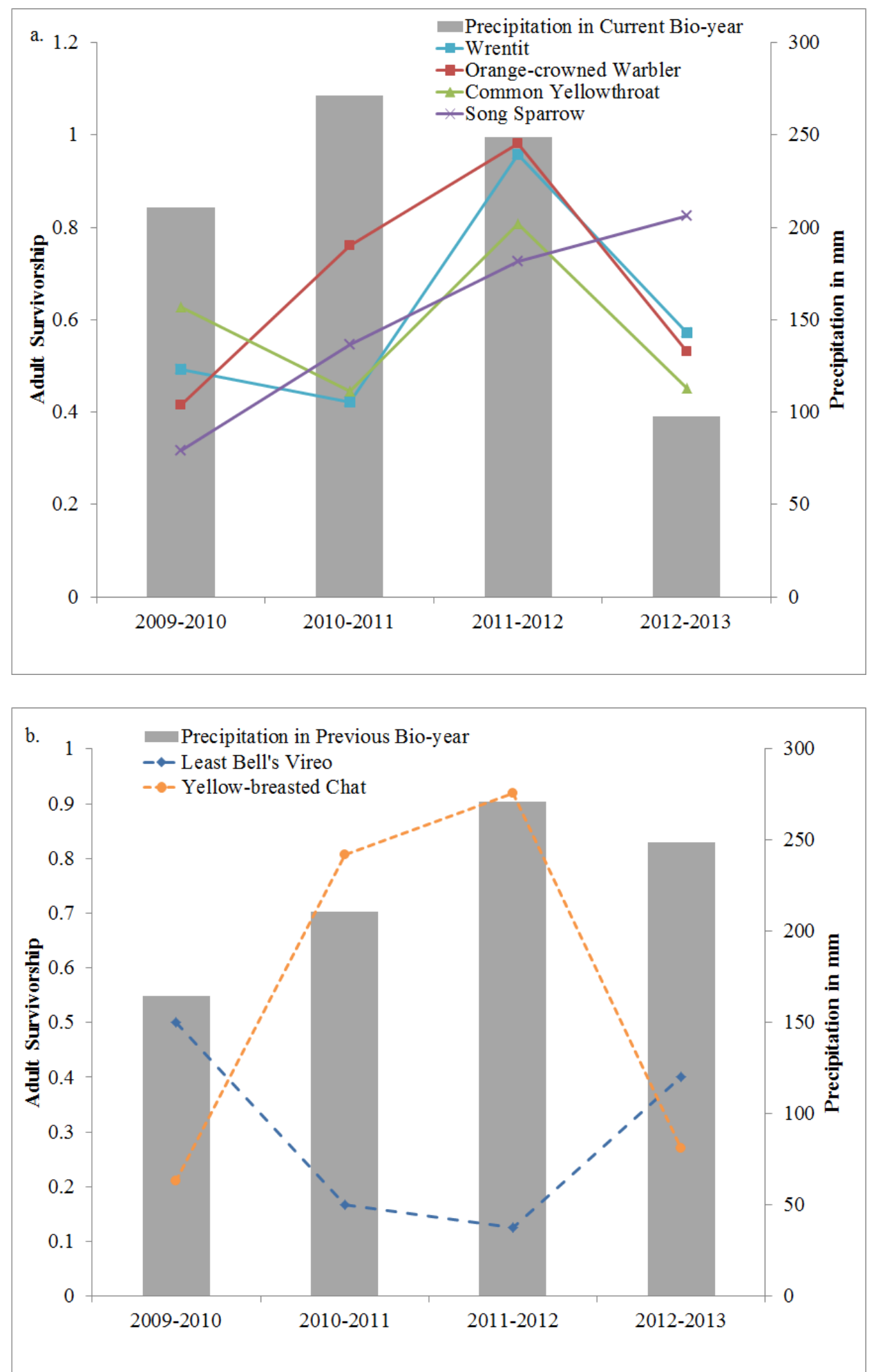

Figure 5. Adult annual survivorship (estimated by Program MARK) for (a) four year-round resident bird species (Wrentit, Orange-crowned Warbler, Common Yellowthroat, and Song Sparrow) and (b) two migratory bird species (Least Bell's Vireo and Yellow Breasted Chat) and precipitation measured for the associated bio-year (July 1-June 30) at Naval Outlying Landing Field, Imperial Beach, southwestern San Diego County, California, California, 2009-13. See appendix A for common and scientific names. 


\section{Discussion}

Of the 10 most abundant species captured from 2009 to 2013 at NOLF, 7 were yearround residents, 1 was present only during migration and winter, and the remaining 2 were migrants that winter elsewhere. This range of resident and migrant species indicates that NOLF provides a diversity and abundance of resources necessary for breeding, wintering, and migration.

Seasonal capture rate patterns for different species reflect differences in life history and breeding patterns. The peak in the capture rate of Wilson's Warbler during May corresponds to the spring migration of this species. This species was not captured after the first week of June in any year. Peaks in capture rates for resident breeding species corresponded to peaks in juvenile captures. These peaks likely represent fledging and juvenile dispersal events. The peak in Bushtit captures in late July and early August likely reflects an increase in movement of extended family groups after the end of the breeding season. In 2012 and 2013, we captured a substantial proportion of the Orange-crowned Warbler and Common Yellowthroat in April, prior to the initial net opening date for the previous 3 years. This validates the decision to begin the MAPS season earlier than the national standard to capture early breeding in this southern climate.

Overall population trends for the species that we captured at NOLF from 2009 to 2013 showed that most year-round resident bird populations were increasing. These trends likely were affected by a balance between productivity and survivorship. One resident species, Wrentit, demonstrated a positive relationship between survivorship and population size. Wrentits experienced a decreasing population trend over 5 years, associated with decreasing survivorship. Productivity was not significantly associated with population size for Wrentit, although there was a non-significant positive association, which may become more apparent with more years of data.

We did not find a significant association between productivity or survivorship and population size for any other resident or migrant species. Similarly, we did not find a significant association between precipitation and either productivity or survivorship. However, productivity and survivorship clearly have an effect on population size, and we should be able to clarify that relationship with more years of data in the future.

Although many of the year-round residents of NOLF seem to have stable or increasing populations, the two migratory species we analyzed demonstrated negative or, at best, stable populations. Migrants are subject to additional pressures that year-round residents do not experience, such as energy expenditure during migration, potential resource depletion during migration or on the wintering grounds, and climate and weather-related stresses that affect regions differently. Migration theory suggests that the benefits of migration for these species necessarily have outweighed the costs. However, as pressure from human populations (for example, development, deforestation, etc.) and climate change affect the wintering grounds over time, the benefits of migration may be insufficient to offset the current costs; therefore, it is not surprising that migratory species may not show increasing population trends. Year-round bird species also may benefit from natural resource management programs on their breeding grounds, providing them with protection that may be lacking on the wintering and migration grounds.

Results from this analysis should be treated cautiously, as they represent only 5 years of data. Building on these data by continuing the MAPS program at NOLF will help to elucidate the interacting contributions of productivity and survivorship to observed patterns in bird populations. 


\section{References Cited}

Allen, K.S., and Kus, B.E., 2014, Neotropical migratory bird monitoring study at Marine Corps Base Camp Pendleton, California - 2013 annual data summary: Prepared for Assistant Chief of Staff, Environmental Security, U.S. Marine Corps Base Camp Pendleton, Camp Pendleton, California.

California Department of Fish and Game, 2011, Special animals: California Department of Fish and Game, accessed March 5, 2014, at http://www.dfg.ca.gov/biogeodata/cnddb/pdfs/SPAnimals.pdf.

California Department of Fish and Wildlife, 2013, State and federally listed endangered and threatened animals of California: California Department of Fish and Wildlife, accessed March 4, 2014, at http://www.dfg.ca.gov/biogeodata/cnddb/pdfs/TEAnimals.pdf.

California Department of Fish and Wildlife, 2014, Fully protected animals: California Department of Fish and Wildlife, accessed March 5, 2014, at http://www.dfg.ca.gov/wildlife/nongame/t_e_spp/fully_pro.html.

DeSante, D.F., Burton, K.M., Velez, P., Froehlich, D., and Kaschube, D., 2011, MAPS manual-Instructions for the establishment and operation of constant-effort bird-banding stations as part of the Monitoring Avian Productivity and Survivorship (MAPS) Program: Point Reyes Station, California, Institute for Bird Populations.

DeSante, D.F., Williams, O.E., and Burton, K.M., 1993, The Monitoring Avian Productivity and Survivorship (MAPS) program - Overview and progress, in Finch, D.M., and Stangel, P.W., eds., Status and management of neotropical migratory birds: U.S. Forest Service, Rocky Mountain Forest and Range Experiment Station, Fort Collins, Colorado, General Technical Report RM-229, p. 208-222.

Kus, B.E., and Kisner, D.A., 2003, Neotropical migratory bird monitoring study at Marine Corps Base Camp Pendleton, California-2002 annual report: Prepared for Assistant Chief of Staff, Environmental Security, U.S. Marine Corps Base Camp Pendleton, Camp Pendleton, California.

Madden, M.C., and Kus, B.E., 2014, Monitoring breeding and migration of neotropical migratory birds at Naval Base Coronado, Remote Training Site, Warner Springs, San Diego County, California—2013 annual data summary: Prepared for Commander, Navy Region Southwest, San Diego, California.

Madden, M. C., S. Lynn, and B. E. Kus. 2014. Monitoring breeding and migration of neotropical migratory birds at Point Loma, San Diego County, California — 2013 annual data summary: Prepared for Commander, Navy Region Southwest, San Diego, California.

Myers, S.J., 2011, Report of MAPS banding at the Naval Outlying Landing Field, Imperial Beach in 2009-2011: Prepared for the Naval Base Coronado, California.

Partners in Flight Science Committee, 2012, Species Assessment Database, version 2012: Partners in Flight Committee, database accessed August, 16, 2014, at http://rmbo.org/pifassessment.

Pyle, P., 1997, Identification guide to North American Birds, Part 1-Columbidae to Ploceidae: Bolinas, California, Slate Creek Press.

The Weather Channel, LLC, 2014, Weather history for Imperial Beach, CA : The Weather Channel, LLC, accessed July 28, 2014, at www.wunderground.com/personal-weatherstation/dashboard?ID=KCAIMPER2\#history/s20080601/e20080701/mmonth. 
U.S. Fish and Wildlife Service, 2008, Birds of conservation concern 2008: U.S. Fish and Wildlife Service, Division of Migratory Bird Management, Arlington, Virginia, 85 p., http://www.fws.gov/migratorybirds/.

U. S. Fish and Wildlife Service, 2013, Neotropical Migratory Bird Conservation Act bird list: U.S. Fish and Wildlife Service Web site, accessed March 5, 2014, at http://www.fws.gov/birdhabitat/grants/nmbca/birdlist.shtm.

U.S. Fish and Wildlife Service, 2014, Endangered species: U.S. Fish and Wildlife Service Web site, accessed March 5, 2014, at http://www.fws.gov/endangered/.

U.S. Navy, 2014, Naval Base Coronado Integrated Natural Resources Management Plan, signed 21 May 2014: U.S. Navy. 


\section{Appendix A. Alpha Codes, Common Names, and Scientific Names for Species Captured and Observed, Naval Outlying Landing Field, Imperial Beach, Southwestern San Diego County, California, 2009-13}

Table A1. Species captured at Naval Outlying Landing Field, Imperial Beach, 2009-13.

[Species in bold were considered breeders at the Naval Outlying Landing Field Monitoring Avian Productivity and Survivorship (MAPS) banding station, Imperial Beach, California, according to MAPS protocol (persistent territorial singing during height of breeding season, and/or "hard evidence" of breeding (observation of nest, fledglings, etc.) at the station (as opposed to larger surrounding area). Special status: CC, Partners in Flight Species of Conservation Concern (U.S. Fish and Wildlife Service, 2008; California Department of Fish and Game, 2011; Partners in Flight Science Committee, 2012; California Department of Fish and Wildlife, 2013, 2014); FC, Federal Species of Conservation Concern; FE, Federally listed as Endangered; SC, State Species of Concern; SE, State listed as Endangered]

\begin{tabular}{|c|c|c|c|}
\hline Alpha code & Common name & Scientific name & Special status \\
\hline $\mathrm{COHA}^{1}$ & Cooper's Hawk & Accipiter cooperii & \\
\hline MODO $^{1}$ & Mourning Dove & Zenaida macroura & \\
\hline COGD & Common Ground-Dove & Columbina passerina & \\
\hline GRRO & Greater Roadrunner & Geococcyx californianus & \\
\hline $\mathrm{BCHU}^{1}$ & Black-chinned Hummingbird & Archilochus alexandri & \\
\hline ANHU $^{1}$ & Anna's Hummingbird & Calypte anna & \\
\hline $\mathrm{CAHU}^{1}$ & Calliope Hummingbird & Selasphorus calliope & $\mathrm{CC}$ \\
\hline RUHU $^{1}$ & Rufous Hummingbird & Selasphorus rufus & $\mathrm{CC}$ \\
\hline $\mathrm{ALHU}^{1}$ & Allen's Hummingbird & Selasphorus sasin & $\mathrm{CC}, \mathrm{FC}$ \\
\hline USHU & Unidentified Selasphorus Hummingbird & Selasphorus spp. & \\
\hline NUWO & Nuttall's Woodpecker & Picoides nuttallii & CC, FC \\
\hline Dowo & Downy Woodpecker & Picoides pubescens & \\
\hline WIFL $^{1}$ & Willow Flycatcher & Empidonax traillii & $\mathrm{SE}$ \\
\hline HAFL $^{1}$ & Hammond's Flycatcher & Empidonax hammondii & \\
\hline PSFL $^{1}$ & Pacific-slope Flycatcher & Empidonax difficilis & \\
\hline BLPH & Black Phoebe & Sayornis nigricans & \\
\hline ATFL $^{1}$ & Ash-throated Flycatcher & Myiarchus cinerascens & \\
\hline LBVI $^{1}$ & Least Bell's Vireo & Vireo bellii pusillus & CC, FE, SE \\
\hline HUVI & Hutton's Vireo & Vireo huttoni & \\
\hline WAVI $^{1}$ & Warbling Vireo & Vireo gilvus & \\
\hline REVI $^{1}$ & Red-eyed Vireo & Vireo olivaceus & \\
\hline TRES $^{1}$ & Tree Swallow & Tachycineta bicolor & \\
\hline $\mathrm{NRWS}^{1}$ & Northern Rough-winged Swallow & Stelgidopteryx serripennis & \\
\hline CLSW $^{1}$ & Cliff Swallow & Petrochelidon pyrrhonota & \\
\hline BUSH & Bushtit & Psaltriparus minimus & \\
\hline BEWR & Bewick's Wren & Thryomanes bewickii & \\
\hline HOWR $^{1}$ & House Wren & Troglodytes aedon & \\
\hline
\end{tabular}




\begin{tabular}{|c|c|c|c|}
\hline Alpha code & Common name & Scientific name & Special status \\
\hline SWTH $^{1}$ & Swainson's Thrush & Catharus ustulatus & \\
\hline HETH $^{1}$ & Hermit Thrush & Catharus guttatus & \\
\hline WREN & Wrentit & Chamaea fasciata & $\mathrm{CC}$ \\
\hline САTH & California Thrasher & Toxostoma redivivum & $\mathrm{CC}$ \\
\hline OCWA $^{1}$ & Orange-crowned Warbler & Oreothlypis celata & \\
\hline NAWA $^{1}$ & Nashville Warbler & Oreothlypis ruficapilla & \\
\hline $\mathrm{NOPA}^{1}$ & Northern Parula & Setophaga americana & \\
\hline YWAR $^{1}$ & Yellow Warbler & Setophaga petechia & SC \\
\hline AUWA $^{1}$ & Audubon's Warbler & Setophaga coronata auduboni & \\
\hline TOWA $^{1}$ & Townsend's Warbler & Setophaga townsendi & \\
\hline HEWA $^{1}$ & Hermit Warbler & Setophaga occidentalis & $\mathrm{CC}$ \\
\hline MGWA $^{1}$ & MacGillivray's Warbler & Geothlypis tolmiei & \\
\hline $\operatorname{COYE}^{1}$ & Common Yellowthroat & Geothlypis trichas & \\
\hline WIWA $^{1}$ & Wilson's Warbler & Cardellina pusilla & \\
\hline $\mathrm{YBCH}^{1}$ & Yellow-breasted Chat & Icteria virens & SC \\
\hline SPTO $^{1}$ & Spotted Towhee & Pipilo maculatus & \\
\hline CALT & California Towhee & Melozone crissalis & $\mathbf{C C}$ \\
\hline FOSP $^{1}$ & Fox Sparrow & Passerella iliaca & \\
\hline $\operatorname{SOSP}^{1}$ & Song Sparrow & Melospiza melodia & \\
\hline LISP $^{1}$ & Lincoln's Sparrow & Melospiza lincolnii & \\
\hline $\mathrm{WCSP}^{1}$ & White-crowned Sparrow & Zonotrichia leucophrys & \\
\hline $\mathrm{GCSP}^{1}$ & Golden-crowned Sparrow & Zonotrichia atricapilla & $\mathrm{CC}$ \\
\hline NOCA & Northern Cardinal & Cardinalis cardinalis & \\
\hline BHGR $^{1}$ & Black-headed Grosbeak & Pheucticus melanocephalus & \\
\hline LAZB $^{1}$ & Lazuli Bunting & Passerina amoena & \\
\hline BHCO $^{1}$ & Brown-headed Cowbird & Molothrus ater & \\
\hline HOOR $^{1}$ & Hooded Oriole & Icterus cucullatus & \\
\hline HOFI & House Finch & Carpodacus mexicanus & \\
\hline LEGO $^{1}$ & Lesser Goldfinch & Spinus psaltria & \\
\hline $\mathrm{LAGO}^{1}$ & Lawrence's Goldfinch & Spinus lawrencei & $\mathrm{CC}, \mathrm{FC}$ \\
\hline AMGO $^{1}$ & American Goldfinch & Spinus tristis & \\
\hline
\end{tabular}

${ }^{1}$ Species defined as Neotropical migratory bird under the Neotropical Migratory Bird Conservation Act of 2000 (U.S. Fish and Wildlife Service, 2013). 
Table A2. Species observed, but not captured at Naval Outlying Landing Field, Imperial Beach, 2009-13.

[Species in bold were considered breeders at the Naval Outlying Landing Field Monitoring Avian Productivity and Survivorship (MAPS) banding station, Imperial Beach, California, according to MAPS protocol (persistent territorial singing during height of breeding season, and/or "hard evidence" of breeding (observation of nest, fledglings, etc.) at the station (as opposed to larger surrounding area). Special status: CC, Partners in Flight Species of Conservation Concern (U.S. Fish and Wildlife Service, 2008; California Department of Fish and Game, 2011; Partners in Flight Science Committee, 2012; California Department of Fish and Wildlife, 2013, 2014); FC, Federal Species of Conservation Concern; SC, State Species of Concern; SE, State listed as Endangered]

\begin{tabular}{|c|c|c|c|}
\hline $\begin{array}{l}\text { Alpha } \\
\text { code }\end{array}$ & Common name & Scientific name & $\begin{array}{l}\text { Special } \\
\text { status }\end{array}$ \\
\hline $\mathrm{DCCO}^{1}$ & Double-crested Cormorant & Phalacrocorax auritus & \\
\hline GBHE $^{1}$ & Great Blue Heron & Ardea herodias & \\
\hline GREG $^{1}$ & Great Egret & Ardea alba & \\
\hline SNEG $^{1}$ & Snowy Egret & Egretta thula & \\
\hline $\mathrm{BCNH}^{1}$ & Black-crowned Night-heron & Nycticorax nycticorax & \\
\hline TUVU & Turkey Vulture & Cathartes aura & \\
\hline $\mathrm{CANG}^{1}$ & Canada Goose & Branta canadensis & \\
\hline MALL $^{1}$ & Mallard & Anas platyrhynchos & \\
\hline $\operatorname{OSPR}^{1}$ & Osprey & Pandion haliaetus & \\
\hline WTKI & White-tailed Kite & Elanus leucurus & FC, SF \\
\hline NOHA $^{1}$ & Northern Harrier & Circus cyaneus & SC \\
\hline RSHA $^{1}$ & Red-shouldered Hawk & Buteo lineatus & \\
\hline RTHA $^{1}$ & Red-tailed Hawk & Buteo jamaicensis & \\
\hline $\mathrm{AMKE}^{1}$ & American Kestrel & Falco sparverius & \\
\hline PEFA $^{1}$ & Peregrine Falcon & Falco peregrinus & $\mathrm{CC}, \mathrm{FC}, \mathrm{SF}$ \\
\hline KILL $^{1}$ & Killdeer & Charadrius vociferus & \\
\hline GRYE $^{1}$ & Greater Yellowlegs & Tringa melanoleuca & \\
\hline WHIM $^{1}$ & Whimbrel & Numenius phaeopus & \\
\hline $\mathrm{LBCU}^{1}$ & Long-billed Curlew & Numenius americanus & $\mathrm{FC}$ \\
\hline $\mathrm{CAGU}^{1}$ & California Gull & Larus californicus & \\
\hline WEGU $^{1}$ & Western Gull & Larus occidentalis & \\
\hline CATE $^{1}$ & Caspian Tern & Hydroprogne caspia & \\
\hline FOTE $^{1}$ & Forster's Tern & Sterna forsteri & \\
\hline BANO & Barn Owl & Tyto alba & \\
\hline GHOW & Great Horned Owl & Bubo virginianus & \\
\hline $\mathrm{COPO}^{1}$ & Common Poorwill & Phalaenoptilus nuttallii & \\
\hline WTSW $^{1}$ & White-throated Swift & Aeronautes saxatalis & \\
\hline $\mathrm{COHU}^{1}$ & Costa's Hummingbird & Calypte costae & $\mathrm{FC}$ \\
\hline UNHU & Unidentified Hummingbird species & --- & \\
\hline ACWO & Acorn Woodpecker & Melanerpes formicivorus & \\
\hline $\mathrm{NOFL}^{1}$ & Northern Flicker & Colaptes auratus & \\
\hline
\end{tabular}




\begin{tabular}{|l|l|l|l|}
\hline $\begin{array}{l}\text { Alpha } \\
\text { code }\end{array}$ & Common name & Scientific name & $\begin{array}{l}\text { Special } \\
\text { status }\end{array}$ \\
\hline WEWP $^{1}$ & Western Wood-pewee & Contopus sordidulus & \\
\hline SAPH $^{1}$ & Say's Phoebe & Sayornis saya & \\
\hline WEKI $^{1}$ & Western Kingbird & Tyrannus verticalis & \\
\hline BTMJ & Black-throated Magpie-jay & Calocitta colliei & \\
\hline WESJ & Western Scrub-Jay & Aphelocoma californica & CC \\
\hline AMCR & American Crow & Corvus brachyrhynchos & \\
\hline CORA $^{1}$ & Common Raven & Corvus corax & \\
\hline VGSW $^{1}$ & Violet-green Swallow & Tachycineta thalassina & \\
\hline BARS $^{1}$ & Barn Swallow & Hirundo rustica & \\
\hline BGGN $^{1}$ & Blue-gray Gnatcatcher & Polioptila caerulea & \\
\hline NOMO & Northern Mockingbird & Mimus polyglottos & \\
\hline EUST $^{\text {EUS }}$ & European Starling & Sturnus vulgaris & \\
\hline PHAI $^{1}$ & Phainopepla & Phainopepla nitens & CC \\
\hline BTYW $^{1}$ & Black-throated Gray Warbler & Setophaga nigrescens & CC \\
\hline OVEN $^{1}$ & Ovenbird & Seiurus aurocapilla & \\
\hline WETA $^{1}$ & Western Tanager & Piranga ludoviciana & \\
\hline CHSP $^{1}$ & Chipping Sparrow & Spizella passerina & \\
\hline BLGR $^{1}$ & Blue Grosbeak & Passerina caerulea & \\
\hline RWBL $^{1}$ & Red-winged Blackbird & Agelaius phoeniceus & \\
\hline BUOR $^{1}$ & Bullock's Oriole & Icterus bullockii & \\
\hline & & & \\
\hline
\end{tabular}

${ }^{1}$ Species defined as Neotropical migratory bird under the Neotropical Migratory Bird Conservation Act of 2000 (U.S. Fish and Wildlife Service, 2013). 


\section{Appendix B. Tables and Additional Figures, Naval Outlying Landing Field, Imperial Beach, Southwestern San Diego County, California, 2009-13}

Table B1. Number of birds captured, banded, recaptured, and unbanded at Naval Outlying Landing Field, Imperial Beach, 2009-13.

[Species: See appendix A for common and scientific names. Total captures: Includes multiple captures of some individuals]

\begin{tabular}{|c|c|c|c|c|c|c|c|c|c|c|c|c|c|c|c|c|c|c|c|c|c|c|c|c|}
\hline \multirow[b]{3}{*}{ Specie } & \multicolumn{6}{|c|}{ Total captures } & \multicolumn{6}{|c|}{ New individuals banded } & \multicolumn{6}{|c|}{ Recaptured individuals } & \multicolumn{6}{|c|}{ Unbanded } \\
\hline & \multicolumn{5}{|c|}{ Year } & \multirow[b]{2}{*}{ Total } & \multicolumn{5}{|c|}{ Year } & \multirow[b]{2}{*}{ Total } & \multicolumn{5}{|c|}{ Year } & \multirow[b]{2}{*}{ Total } & \multicolumn{5}{|c|}{ Year } & \multirow[b]{2}{*}{ Total } \\
\hline & 2009 & 2010 & 2011 & $2012^{1}$ & 20131 & & 2009 & 2010 & 2011 & $2012^{1}$ & $2013^{1}$ & & 2009 & 2010 & 2011 & $2012^{1}$ & $2013^{1}$ & & 2009 & 2010 & 2011 & $2012^{1}$ & 20131 & \\
\hline $\mathrm{COHA}$ & 0 & 0 & 1 & 0 & 0 & 1 & 0 & 0 & 1 & 0 & 0 & 1 & 0 & 0 & 0 & 0 & 0 & $\mathbf{0}$ & 0 & 0 & 0 & 0 & 0 & $\mathbf{0}$ \\
\hline MOD & 0 & 0 & 0 & 1 & 1 & 2 & 0 & 0 & 0 & 0 & 0 & $\mathbf{0}$ & 0 & 0 & 0 & 0 & 0 & $\mathbf{0}$ & 0 & 0 & 0 & 1 & 1 & 2 \\
\hline COGD & 2 & 2 & 0 & 2 & 5 & 11 & 2 & 2 & 0 & 2 & 3 & 9 & 0 & 0 & 0 & 0 & 0 & $\mathbf{0}$ & 0 & 0 & 0 & 0 & 1 & 1 \\
\hline GRRO & 0 & 0 & 0 & 1 & 0 & 1 & 0 & 0 & 0 & 0 & 0 & 0 & 0 & 0 & 0 & 0 & 0 & $\mathbf{0}$ & 0 & 0 & 0 & 1 & 0 & 1 \\
\hline $\mathrm{BCHU}$ & 1 & 3 & 4 & 4 & 5 & 17 & 0 & 0 & 0 & 0 & 0 & 0 & 0 & 0 & 0 & 0 & 0 & 0 & 1 & 3 & 4 & 4 & 5 & 17 \\
\hline ANHU & 8 & 11 & 8 & 25 & 33 & 85 & 0 & 0 & 0 & 0 & 0 & 0 & 0 & 0 & 0 & 0 & 0 & 0 & 8 & 11 & 8 & 25 & 33 & 85 \\
\hline CAHU & 0 & 0 & 0 & 1 & 2 & 3 & 0 & 0 & 0 & 0 & 0 & 0 & 0 & 0 & 0 & 0 & 0 & 0 & 0 & 0 & 0 & 1 & 2 & 3 \\
\hline RUHU & 0 & 0 & 0 & 3 & 3 & 6 & 0 & 0 & 0 & 0 & 0 & 0 & 0 & 0 & 0 & 0 & 0 & $\overline{0}$ & 0 & 0 & 0 & 3 & 3 & 6 \\
\hline ALHU & 0 & 0 & 0 & 3 & 1 & 4 & 0 & 0 & 0 & 0 & 0 & 0 & 0 & 0 & 0 & 0 & 0 & 0 & 0 & 0 & 0 & 3 & 1 & 4 \\
\hline USHU & 0 & 0 & 0 & 1 & 0 & 1 & 0 & 0 & 0 & 0 & 0 & 0 & 0 & 0 & 0 & 0 & 0 & $\mathbf{0}$ & 0 & 0 & 0 & 1 & 0 & 1 \\
\hline NUW & 0 & 3 & 1 & 3 & 2 & 9 & 0 & 3 & 1 & 3 & 2 & 9 & 0 & 0 & 0 & 0 & 0 & $\mathbf{0}$ & 0 & 0 & 0 & 0 & 0 & 0 \\
\hline DOW & 0 & 4 & 4 & 13 & 5 & 26 & 0 & 4 & 4 & 11 & 5 & 24 & 0 & 0 & 0 & 0 & 0 & 0 & 0 & 0 & 0 & 0 & 0 & 0 \\
\hline WIFL & 0 & 0 & 3 & 1 & 3 & 7 & 0 & 0 & 3 & 1 & 3 & 7 & 0 & 0 & 0 & 0 & 0 & $\mathbf{0}$ & 0 & 0 & 0 & 0 & 0 & $\mathbf{0}$ \\
\hline HAFL & 0 & 0 & 1 & 0 & 0 & 1 & 0 & 0 & 1 & 0 & 0 & 1 & 0 & 0 & 0 & 0 & 0 & 0 & 0 & 0 & 0 & 0 & 0 & $\overline{0}$ \\
\hline PSFL & 15 & 17 & 10 & 11 & 9 & 62 & 14 & 17 & 10 & 10 & 9 & 60 & 0 & 0 & 0 & 0 & 0 & 0 & 0 & 0 & 0 & 1 & 0 & 1 \\
\hline BLPH & 1 & 0 & 0 & 1 & 0 & 2 & 1 & 0 & 0 & 1 & 0 & 2 & 0 & 0 & 0 & 0 & 0 & 0 & 0 & 0 & 0 & 0 & 0 & $\overline{0}$ \\
\hline ATFL & 4 & 1 & 2 & 6 & 5 & 18 & 4 & 1 & 2 & 6 & 5 & 18 & 0 & 0 & 0 & 0 & 0 & 0 & 0 & 0 & 0 & 0 & 0 & $\overline{0}$ \\
\hline$\overline{\text { LBVI }}$ & 11 & 14 & 20 & 8 & 16 & 69 & 7 & 10 & 16 & 4 & 10 & 47 & 0 & 3 & 1 & 1 & 2 & 7 & 0 & 0 & 1 & 0 & 0 & 1 \\
\hline HUVI & $\overline{0}$ & 1 & 5 & 9 & 3 & 18 & 0 & 1 & 5 & 8 & 3 & 17 & 0 & 0 & 0 & 0 & 0 & 0 & 0 & 0 & 0 & 0 & 0 & $\overline{0}$ \\
\hline WAVI & 1 & 2 & 10 & 5 & 7 & 25 & 1 & 2 & 10 & 5 & 6 & 24 & 0 & 0 & 0 & 0 & 0 & 0 & 0 & 0 & 0 & 0 & 1 & 1 \\
\hline REVI & 1 & 0 & 0 & 0 & 1 & 2 & 1 & 0 & 0 & 0 & 1 & 2 & 0 & 0 & 0 & 0 & 0 & 0 & 0 & 0 & 0 & 0 & 0 & $\overline{0}$ \\
\hline TRES & 0 & 0 & 0 & 1 & 0 & 1 & 0 & 0 & 0 & 1 & 0 & 1 & 0 & 0 & 0 & 0 & 0 & 0 & 0 & 0 & 0 & 0 & 0 & $\overline{0}$ \\
\hline NRWS & 0 & 1 & 0 & 0 & 1 & 2 & 0 & 1 & 0 & 0 & 1 & 2 & 0 & 0 & 0 & 0 & 0 & 0 & 0 & 0 & 0 & 0 & 0 & $\mathbf{0}$ \\
\hline CLSW & 0 & 0 & 0 & 7 & 0 & 7 & 0 & 0 & 0 & 7 & 0 & 7 & 0 & 0 & 0 & 0 & 0 & 0 & 0 & 0 & 0 & 0 & 0 & 0 \\
\hline BUSH & 128 & 119 & 105 & 156 & 116 & 624 & 100 & 93 & 76 & 107 & 72 & 448 & 0 & 5 & 13 & 22 & 14 & 54 & 13 & 7 & 4 & 5 & 4 & 33 \\
\hline BEWR & 21 & 18 & 12 & 23 & 16 & 90 & 18 & 17 & 8 & 17 & 11 & 71 & 0 & 1 & 3 & 2 & 4 & 10 & 1 & 1 & 1 & 1 & 0 & 4 \\
\hline HOW & 13 & 30 & 12 & 30 & 38 & 123 & 10 & 22 & 9 & 23 & 21 & 85 & 0 & 4 & 2 & 4 & 5 & 15 & 2 & 2 & 1 & 0 & 3 & $\overline{8}$ \\
\hline
\end{tabular}




\begin{tabular}{|c|c|c|c|c|c|c|c|c|c|c|c|c|c|c|c|c|c|c|c|c|c|c|c|c|}
\hline \multirow[b]{3}{*}{ Specie } & \multicolumn{6}{|c|}{ Total captures } & \multicolumn{6}{|c|}{ New individuals banded } & \multicolumn{6}{|c|}{ Recaptured individuals } & \multicolumn{6}{|c|}{ Unbanded } \\
\hline & \multicolumn{5}{|c|}{ Year } & \multirow[b]{2}{*}{ Total } & \multicolumn{5}{|c|}{ Year } & \multirow[b]{2}{*}{ Total } & \multicolumn{5}{|c|}{ Year } & \multirow[b]{2}{*}{ Total } & \multicolumn{5}{|c|}{ Year } & \multirow[b]{2}{*}{ Total } \\
\hline & 2009 & 2010 & 2011 & $2012^{1}$ & $2013^{1}$ & & 2009 & 2010 & 2011 & $2012^{1}$ & $2013^{1}$ & & 2009 & 2010 & 2011 & $2012^{1}$ & $2013^{1}$ & & 2009 & 2010 & 2011 & $2012^{1}$ & $2013^{1}$ & \\
\hline SWTH & 4 & 16 & 16 & 11 & 7 & 54 & 4 & 16 & 16 & 11 & 7 & 54 & 0 & 0 & 0 & 0 & 0 & $\mathbf{0}$ & 0 & 0 & 0 & 0 & 0 & $\mathbf{0}$ \\
\hline HETH & 0 & 0 & 0 & 5 & 2 & 7 & 0 & 0 & 0 & 5 & 2 & 7 & 0 & 0 & 0 & 0 & 0 & $\mathbf{0}$ & 0 & 0 & 0 & 0 & 0 & $\mathbf{0}$ \\
\hline WREN & 30 & 36 & 13 & 32 & 19 & 130 & 23 & 23 & 5 & 19 & 8 & 78 & 0 & 1 & 6 & 6 & 7 & 20 & 1 & 0 & 0 & 1 & 0 & 2 \\
\hline CATH & 0 & 4 & 1 & 3 & 4 & 12 & 0 & 3 & 0 & 2 & 3 & 8 & 0 & 0 & 0 & 0 & 0 & $\mathbf{0}$ & 0 & 0 & 1 & 1 & 0 & 2 \\
\hline OCW & 55 & 76 & 27 & 84 & 109 & 351 & 52 & 68 & 23 & 61 & 91 & 295 & 0 & 5 & 3 & 12 & 9 & 29 & 2 & 2 & 1 & 0 & 0 & 5 \\
\hline NAW & 0 & 0 & 3 & 0 & 0 & 3 & 0 & 0 & 3 & 0 & 0 & 3 & 0 & 0 & 0 & 0 & 0 & 0 & 0 & 0 & 0 & 0 & 0 & 0 \\
\hline NOPA & 1 & 0 & 0 & 0 & 0 & 1 & 1 & 0 & 0 & 0 & 0 & 1 & 0 & 0 & 0 & 0 & 0 & 0 & 0 & 0 & 0 & 0 & 0 & $\mathbf{0}$ \\
\hline YWA & 5 & 15 & 7 & 24 & 8 & 59 & 4 & 14 & 7 & 20 & 6 & 51 & 0 & 0 & 0 & 0 & 1 & 1 & 0 & 0 & 0 & 0 & 1 & 1 \\
\hline AUW & 0 & 0 & 0 & 10 & 2 & 12 & 0 & 0 & 0 & 10 & 2 & 12 & 0 & 0 & 0 & 0 & 0 & 0 & 0 & 0 & 0 & 0 & 0 & 0 \\
\hline TOWA & 0 & 0 & 1 & 1 & 0 & 2 & 0 & 0 & 1 & 1 & 0 & 2 & 0 & 0 & 0 & 0 & 0 & 0 & 0 & 0 & 0 & 0 & 0 & 0 \\
\hline HEWA & 0 & 0 & 0 & 1 & 2 & 3 & 0 & 0 & 0 & 1 & 2 & 3 & 0 & 0 & 0 & 0 & 0 & 0 & 0 & 0 & 0 & 0 & 0 & 0 \\
\hline MGW & 1 & 0 & 1 & 0 & 3 & 5 & 1 & 0 & 1 & 0 & 3 & 5 & 0 & 0 & 0 & 0 & 0 & 0 & 0 & 0 & 0 & 0 & 0 & 0 \\
\hline COYE & 113 & 70 & 51 & 118 & 93 & 445 & 92 & 54 & 40 & 86 & 68 & 340 & 0 & 1 & 6 & 10 & 11 & 28 & 7 & 3 & 0 & 2 & 1 & 13 \\
\hline WIWA & 8 & 49 & 36 & 25 & 18 & 136 & 8 & 45 & 35 & 25 & 18 & 131 & 0 & 0 & 0 & 0 & 0 & 0 & 0 & 3 & 1 & 0 & 0 & 4 \\
\hline $\mathrm{YBCH}$ & 25 & 14 & 8 & 11 & 12 & 70 & 21 & 12 & 3 & 7 & 9 & 52 & 0 & 6 & 2 & 2 & 1 & 11 & 1 & 0 & 0 & 0 & 0 & 1 \\
\hline SPTO & 3 & 5 & 3 & 10 & 8 & 29 & 2 & 5 & 2 & 5 & 7 & 21 & 0 & 0 & 1 & 2 & & 3 & 0 & 0 & 0 & 0 & 0 & 0 \\
\hline CALT & 2 & 6 & 3 & 6 & 6 & 23 & 2 & 6 & 2 & 6 & 6 & 22 & 0 & 0 & 0 & 0 & 0 & $\mathbf{0}$ & 0 & 0 & 1 & 0 & 0 & 1 \\
\hline FOSP & 0 & 0 & 0 & 0 & 1 & 1 & 0 & 0 & 0 & 0 & 1 & 1 & 0 & 0 & 0 & 0 & 0 & 0 & 0 & 0 & 0 & 0 & 0 & 0 \\
\hline$\overline{\text { SOSP }}$ & 82 & 74 & 80 & 111 & 143 & 490 & 69 & 58 & 66 & 86 & 103 & 382 & 0 & 0 & 7 & 10 & 20 & 37 & 4 & 5 & 2 & 2 & 2 & 15 \\
\hline LISP & 0 & 0 & 0 & 4 & 8 & 12 & 0 & 0 & 0 & 4 & 8 & 12 & 0 & 0 & 0 & 0 & 0 & 0 & 0 & 0 & 0 & 0 & 0 & $\mathbf{0}$ \\
\hline WCSP & 0 & 1 & 1 & 21 & 28 & 51 & 0 & 1 & 1 & 20 & 25 & 47 & 0 & 0 & 0 & 0 & 1 & 1 & 0 & 0 & 0 & 1 & 2 & 3 \\
\hline GCSP & 0 & 0 & 1 & 3 & 2 & 6 & 0 & 0 & 1 & 3 & 1 & 5 & 0 & 0 & 0 & 0 & 1 & 1 & 0 & 0 & 0 & 0 & 0 & 0 \\
\hline NOCA & 0 & 0 & 1 & 0 & 0 & 1 & 0 & 0 & 1 & 0 & 0 & 1 & 0 & 0 & 0 & 0 & 0 & 0 & 0 & 0 & 0 & 0 & 0 & 0 \\
\hline BHGR & 0 & 0 & 0 & 2 & 1 & 3 & 0 & 0 & 0 & 2 & 1 & 3 & 0 & 0 & 0 & 0 & 0 & o & 0 & 0 & 0 & 0 & 0 & $\mathbf{0}$ \\
\hline LAZB & 0 & 1 & 0 & 0 & 0 & 1 & 0 & 1 & 0 & 0 & 0 & 1 & 0 & 0 & 0 & 0 & 0 & 0 & 0 & 0 & 0 & 0 & 0 & 0 \\
\hline $\mathrm{BHCO}$ & 0 & 0 & 0 & 0 & 1 & 1 & 0 & 0 & 0 & 0 & 0 & 0 & 0 & 0 & 0 & 0 & 0 & 0 & 0 & 0 & 0 & 0 & 1 & 1 \\
\hline HOOR & 1 & 0 & 0 & 0 & 1 & 2 & 1 & 0 & 0 & 0 & 1 & 2 & 0 & 0 & 0 & 0 & 0 & 0 & 0 & 0 & 0 & 0 & 0 & $\mathbf{0}$ \\
\hline HOFI & 1 & 3 & 6 & 24 & 22 & 56 & 1 & 3 & 6 & 24 & 21 & 55 & 0 & 0 & 0 & 0 & 1 & 1 & 0 & 0 & 0 & 0 & 0 & $\mathbf{0}$ \\
\hline LEGO & 1 & 1 & 0 & 2 & 3 & 7 & 1 & 1 & 0 & 2 & 1 & 5 & 0 & 0 & 0 & 0 & 0 & o & 0 & 0 & 0 & 0 & 2 & 2 \\
\hline LAGO & 0 & 0 & 0 & 3 & 0 & 3 & 0 & 0 & 0 & 3 & 0 & 3 & 0 & 0 & 0 & 0 & 0 & 0 & 0 & 0 & 0 & 0 & 0 & $\mathbf{0}$ \\
\hline AMG & 4 & 5 & 10 & 5 & 4 & 28 & 3 & 5 & 10 & 5 & 4 & 27 & 0 & 0 & 0 & 0 & 0 & 0 & 0 & 0 & 0 & 0 & 0 & 0 \\
\hline Total & 542 & 602 & 467 & 831 & 779 & 3,221 & 443 & 488 & 369 & 614 & 550 & 2,464 & 0 & 26 & 44 & 71 & 77 & 218 & 40 & 37 & 25 & 53 & 63 & 218 \\
\hline
\end{tabular}

${ }^{1}$ Includes captures from 13 banding days compared to 10 banding days per year in 2009-11. 
Table B2. Capture rate of individuals by Monitoring Avian Productivity and Survivorship (MAPS) period and year at Naval Outlying Landing Field, Imperial Beach, 2009-13.

\begin{tabular}{|c|c|c|c|c|c|c|c|}
\hline \multirow{2}{*}{$\begin{array}{l}\text { MAPS } \\
\text { period }\end{array}$} & & \multicolumn{5}{|c|}{ Year } & \multirow{2}{*}{$\frac{\text { Totals by }}{\text { MAPS period }}$} \\
\hline & & 2009 & 2010 & 2011 & 2012 & 2013 & \\
\hline \multirow[b]{3}{*}{-3} & \multirow{3}{*}{$\begin{array}{l}\text { Net-hours } \\
\text { Captures } \\
\text { Captures per } 100 \text { net-hours }\end{array}$} & - & - & - & $61: 20$ & $60: 00$ & 121:20 \\
\hline & & - & - & - & 79 & 66 & 145 \\
\hline & & - & - & - & 129 & 110 & 120 \\
\hline \multirow[b]{3}{*}{-2} & \multirow{3}{*}{$\begin{array}{l}\text { Net-hours } \\
\text { Captures } \\
\text { Captures per } 100 \text { net-hours }\end{array}$} & - & - & - & $59: 30$ & $61: 40$ & 121:10 \\
\hline & & - & - & - & 48 & 77 & 125 \\
\hline & & - & - & - & 81 & 125 & 103 \\
\hline \multirow[b]{3}{*}{-1} & \multirow{3}{*}{$\begin{array}{l}\text { Net-hours } \\
\text { Captures } \\
\text { Captures per } 100 \text { net-hours }\end{array}$} & - & - & - & $44: 20$ & $60: 00$ & 104:20 \\
\hline & & - & - & - & 65 & 54 & 119 \\
\hline & & - & - & - & 147 & 90 & 114 \\
\hline \multirow[b]{3}{*}{1} & \multirow{3}{*}{$\begin{array}{l}\text { Net-hours } \\
\text { Captures } \\
\text { Captures per } 100 \text { net-hours }\end{array}$} & $60: 00$ & $60: 00$ & $60: 00$ & $60: 00$ & $61: 40$ & 301:40 \\
\hline & & 49 & 53 & 63 & 76 & 54 & 295 \\
\hline & & 82 & 88 & 105 & 127 & 88 & 98 \\
\hline \multirow[b]{3}{*}{2} & \multirow{3}{*}{$\begin{array}{l}\text { Net-hours } \\
\text { Captures } \\
\text { Captures per } 100 \text { net-hours }\end{array}$} & $60: 00$ & $60: 00$ & $60: 00$ & $60: 20$ & $56: 20$ & 296:40 \\
\hline & & 79 & 97 & 54 & 101 & 67 & 398 \\
\hline & & 132 & 162 & 90 & 167 & 119 & 134 \\
\hline \multirow[b]{3}{*}{3} & \multirow{3}{*}{$\begin{array}{l}\text { Net-hours } \\
\text { Captures } \\
\text { Captures per } 100 \text { net-hours }\end{array}$} & $60: 00$ & $60: 00$ & $60: 00$ & $61: 00$ & $60: 00$ & 301:00 \\
\hline & & 70 & 84 & 50 & 42 & 68 & 314 \\
\hline & & 117 & 140 & 83 & 69 & 113 & 104 \\
\hline \multirow[b]{3}{*}{4} & \multirow{3}{*}{$\begin{array}{l}\text { Net-hours } \\
\text { Captures } \\
\text { Captures per } 100 \text { net-hours }\end{array}$} & $60: 00$ & $60: 00$ & $60: 00$ & 59:10 & $60: 00$ & 299:10 \\
\hline & & 83 & 44 & 34 & 49 & 63 & 273 \\
\hline & & 138 & 73 & 57 & 83 & 105 & 91 \\
\hline \multirow[b]{3}{*}{5} & \multirow{3}{*}{$\begin{array}{l}\text { Net-hours } \\
\text { Captures } \\
\text { Captures per } 100 \text { net-hours }\end{array}$} & $60: 00$ & $60: 00$ & $60: 00$ & $60: 00$ & $60: 00$ & 300:00 \\
\hline & & 60 & 47 & 56 & 65 & 35 & 263 \\
\hline & & 100 & 78 & 93 & 108 & 58 & 88 \\
\hline \multirow[b]{3}{*}{6} & \multirow{3}{*}{$\begin{array}{l}\text { Net-hours } \\
\text { Captures } \\
\text { Captures per } 100 \text { net-hours }\end{array}$} & $60: 00$ & $60: 00$ & $60: 00$ & $60: 40$ & $60: 00$ & 300:40 \\
\hline & & 14 & 77 & 39 & 48 & 45 & 223 \\
\hline & & 23 & 128 & 65 & 79 & 75 & 74 \\
\hline \multirow[b]{3}{*}{7} & \multirow{3}{*}{$\begin{array}{l}\text { Net-hours } \\
\text { Captures } \\
\text { Captures per } 100 \text { net-hours }\end{array}$} & $60: 00$ & $60: 00$ & $60: 00$ & 59:40 & $60: 00$ & 299:40 \\
\hline & & 38 & 55 & 22 & 29 & 45 & 189 \\
\hline & & 63 & 92 & 37 & 49 & 75 & 63 \\
\hline & Net-hours & $60: 00$ & $60: 00$ & $60: 00$ & $57: 20$ & $60: 00$ & 297:20 \\
\hline & Captures & 27 & 23 & 28 & 33 & 29 & 140 \\
\hline 8 & Captures per 100 net-hours & 45 & 38 & 47 & 58 & 48 & 47 \\
\hline & Net-hours & $60: 00$ & $60: 00$ & $60: 00$ & $60: 00$ & $61: 40$ & 301:40 \\
\hline & Captures & 20 & 26 & 32 & 26 & 35 & 139 \\
\hline 9 & Captures per 100 net-hours & 33 & 43 & 53 & 43 & 57 & 46 \\
\hline & Net-hours & $60: 00$ & $60: 00$ & $60: 00$ & $60: 40$ & $61: 40$ & 302:20 \\
\hline & Captures & 12 & 22 & 47 & 61 & 33 & 175 \\
\hline 10 & Captures per 100 net-hours & 20 & 37 & 78 & 101 & 54 & 58 \\
\hline Totals & Net-hours & $600: 00$ & $600: 00$ & $600: 00$ & $764: 00$ & $783: 00$ & 3347:00 \\
\hline $\begin{array}{c}\text { by } \\
\text { MAPS }\end{array}$ & Captures & 452 & 528 & 425 & 722 & 671 & 2798 \\
\hline period & Captures per 100 net-hours & 75 & 88 & 71 & 95 & 86 & 84 \\
\hline
\end{tabular}


Table B3. Number of captures by Monitoring Avian Productivity and Survivorship (MAPS) period and date at Naval Outlying Landing Field, Imperial Beach, 2009.

[Species: See appendix A for common and scientific names]

\begin{tabular}{|c|c|c|c|c|c|c|c|c|c|c|c|c|}
\hline \multirow[b]{4}{*}{ Species } & \multicolumn{10}{|c|}{ MAPS period } & \multirow[b]{4}{*}{ Total } & \multirow{4}{*}{$\begin{array}{c}\text { Captures } \\
\text { per } 100 \\
\text { net-hours } \\
\text { (600:00:00 } \\
\text { total net- } \\
\text { hours) } \\
\end{array}$} \\
\hline & 1 & 2 & 3 & 4 & 5 & 6 & 7 & 8 & 9 & 10 & & \\
\hline & \multicolumn{10}{|c|}{ Date } & & \\
\hline & $\begin{array}{l}8 \\
0 \\
1 \\
0 \\
1 \\
n \\
0\end{array}$ & $\begin{array}{l}\text { oे } \\
1 \\
\overline{1} \\
\stackrel{1}{6}\end{array}$ & $\begin{array}{l}\stackrel{\rho}{0} \\
\hat{1} \\
\hat{1} \\
\hat{o}\end{array}$ & $\begin{array}{l}8 \\
\text { ô } \\
1 \\
0 \\
1 \\
0 \\
8\end{array}$ & \begin{tabular}{l}
$g$ \\
1 \\
1 \\
\multirow{1}{1}{} \\
$b$ \\
0
\end{tabular} & 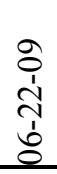 & $\begin{array}{l}8 \\
0 \\
1 \\
0 \\
1 \\
1 \\
0\end{array}$ & $\begin{array}{l}8 \\
0 \\
\frac{1}{1} \\
\frac{1}{0} \\
0\end{array}$ & \begin{tabular}{l}
8 \\
0 \\
1 \\
\multirow{1}{1}{} \\
1 \\
0
\end{tabular} & $\begin{array}{l}\text { oे } \\
+ \\
\dot{1} \\
1 \\
1 \\
0 \\
0\end{array}$ & & \\
\hline COGD & 0 & 1 & 0 & 0 & 0 & 0 & 0 & 0 & 0 & 1 & 2 & 0.33 \\
\hline BCHU & 0 & 0 & 0 & 1 & 0 & 0 & 0 & 0 & 0 & 0 & 1 & 0.17 \\
\hline ANHU & 2 & 2 & 0 & 2 & 0 & 0 & 2 & 0 & 0 & 0 & 8 & 1.33 \\
\hline PSFL & 1 & 0 & 1 & 6 & 3 & 0 & 1 & 0 & 1 & 1 & 14 & 2.33 \\
\hline BLPH & 0 & 1 & 0 & 0 & 0 & 0 & 0 & 0 & 0 & 0 & 1 & 0.17 \\
\hline ATFL & 0 & 1 & 0 & 3 & 0 & 0 & 0 & 0 & 0 & 0 & 4 & 0.67 \\
\hline LBVI & 1 & 4 & 0 & 1 & 0 & 0 & 0 & 0 & 0 & 1 & 7 & 1.17 \\
\hline WAVI & 0 & 1 & 0 & 0 & 0 & 0 & 0 & 0 & 0 & 0 & 1 & 0.17 \\
\hline REVI & 0 & 0 & 0 & 1 & 0 & 0 & 0 & 0 & 0 & 0 & 1 & 0.17 \\
\hline BUSH & 2 & 14 & 18 & 17 & 16 & 1 & 12 & 11 & 8 & 1 & 100 & 16.67 \\
\hline BEWR & 4 & 0 & 4 & 1 & 1 & 0 & 2 & 6 & 0 & 0 & 18 & 3.00 \\
\hline HOWR & 0 & 3 & 0 & 2 & 1 & 1 & 0 & 0 & 2 & 1 & 10 & 1.67 \\
\hline SWTH & 3 & 1 & 0 & 0 & 0 & 0 & 0 & 0 & 0 & 0 & 4 & 0.67 \\
\hline WREN & 0 & 0 & 9 & 6 & 2 & 1 & 2 & 3 & 0 & 0 & 23 & 3.83 \\
\hline OCWA & 2 & 24 & 12 & 6 & 3 & 0 & 0 & 1 & 2 & 2 & 52 & 8.67 \\
\hline NOPA & 0 & 0 & 0 & 0 & 0 & 0 & 1 & 0 & 0 & 0 & 1 & 0.17 \\
\hline YWAR & 0 & 1 & 1 & 1 & 0 & 0 & 0 & 0 & 0 & 1 & 4 & 0.67 \\
\hline MGWA & 1 & 0 & 0 & 0 & 0 & 0 & 0 & 0 & 0 & 0 & 1 & 0.17 \\
\hline COYE & 10 & 7 & 7 & 18 & 25 & 6 & 11 & 4 & 3 & 1 & 92 & 15.33 \\
\hline WIWA & 7 & 1 & 0 & 0 & 0 & 0 & 0 & 0 & 0 & 0 & 8 & 1.33 \\
\hline $\mathrm{YBCH}$ & 3 & 3 & 1 & 2 & 1 & 3 & 4 & 1 & 2 & 1 & 21 & 3.50 \\
\hline SPTO & 0 & 0 & 0 & 1 & 0 & 0 & 0 & 0 & 1 & 0 & 2 & 0.33 \\
\hline CALT & 0 & 0 & 1 & 1 & 0 & 0 & 0 & 0 & 0 & 0 & 2 & 0.33 \\
\hline SOSP & 13 & 15 & 15 & 12 & 6 & 2 & 2 & 1 & 1 & 2 & 69 & 11.50 \\
\hline HOOR & 0 & 0 & 0 & 0 & 1 & 0 & 0 & 0 & 0 & 0 & 1 & 0.17 \\
\hline HOFI & 0 & 0 & 0 & 0 & 0 & 0 & 1 & 0 & 0 & 0 & 1 & 0.17 \\
\hline LEGO & 0 & 0 & 1 & 0 & 0 & 0 & 0 & 0 & 0 & 0 & 1 & 0.17 \\
\hline AMGO & 0 & 0 & 0 & 2 & 1 & 0 & 0 & 0 & 0 & 0 & 3 & 0.50 \\
\hline $\begin{array}{c}\text { Captures per } \\
\text { day }\end{array}$ & 49 & 79 & 70 & 83 & 60 & 14 & 38 & 27 & 20 & 12 & 452 & 75.33 \\
\hline Total species & 12 & 15 & 11 & 18 & 11 & 6 & 10 & 7 & 8 & 10 & 28 & 4.67 \\
\hline
\end{tabular}


Table B4. Number of captures by Monitoring Avian Productivity and Survivorship (MAPS) period and date at Naval Outlying Landing Field, Imperial Beach, 2010.

[Species: See appendix A for common and scientific names]

\begin{tabular}{|c|c|c|c|c|c|c|c|c|c|c|c|c|}
\hline \multirow[b]{4}{*}{ Species } & \multicolumn{10}{|c|}{ MAPS period } & \multirow[b]{4}{*}{ Total } & \multirow[b]{4}{*}{$\begin{array}{c}\text { Captures } \\
\text { per } 100 \\
\text { net-hours } \\
\text { (600:00:00 } \\
\text { total net- } \\
\text { hours) } \\
\end{array}$} \\
\hline & 1 & 2 & 3 & 4 & 5 & 6 & 7 & 8 & 9 & 10 & & \\
\hline & \multicolumn{10}{|c|}{ Date } & & \\
\hline & $\begin{array}{l}0 \\
1 \\
\vdots \\
0 \\
1 \\
0 \\
0\end{array}$ & $\begin{array}{l}\stackrel{0}{1} \\
\frac{1}{2} \\
\dot{n} \\
\stackrel{2}{0}\end{array}$ & 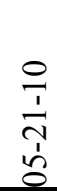 & $\begin{array}{l}0 \\
1 \\
\hat{1} \\
1 \\
1 \\
0\end{array}$ & $\begin{array}{l}0 \\
1 \\
1 \\
1 \\
0\end{array}$ & $\begin{array}{l}0 \\
1 \\
\text { ñ } \\
\text { bे }\end{array}$ & $\begin{array}{l}0 \\
1 \\
\hat{0} \\
1 \\
\frac{1}{0}\end{array}$ & $\frac{0}{\frac{1}{2}} \frac{1}{\frac{1}{0}}$ & 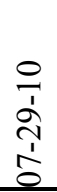 & $\begin{array}{l}0 \\
\stackrel{1}{1} \\
\stackrel{1}{0} \\
1 \\
\infty \\
0\end{array}$ & & \\
\hline COGD & 0 & 0 & 0 & 1 & 0 & 0 & 0 & 0 & 0 & 1 & 2 & 0.33 \\
\hline BCHU & 1 & 0 & 0 & 0 & 0 & 1 & 1 & 0 & 0 & 0 & 3 & 0.50 \\
\hline ANHU & 1 & 2 & 3 & 0 & 2 & 0 & 1 & 0 & 2 & 0 & 11 & 1.83 \\
\hline NUWO & 1 & 0 & 0 & 1 & 0 & 1 & 0 & 0 & 0 & 0 & 3 & $\mathbf{0 . 5 0}$ \\
\hline DOWO & 1 & 0 & 1 & 0 & 1 & 0 & 0 & 1 & 0 & 0 & 4 & 0.67 \\
\hline PSFL & 2 & 4 & 4 & 3 & 1 & 0 & 0 & 0 & 1 & 2 & 17 & 2.83 \\
\hline ATFL & 0 & 0 & 0 & 0 & 0 & 0 & 0 & 0 & 0 & 1 & 1 & 0.17 \\
\hline LBVI & 1 & 1 & 0 & 0 & 3 & 4 & 2 & 1 & 1 & 0 & 13 & 2.17 \\
\hline HUVI & 0 & 0 & 0 & 0 & 0 & 0 & 1 & 0 & 0 & 0 & 1 & 0.17 \\
\hline WAVI & 0 & 2 & 0 & 0 & 0 & 0 & 0 & 0 & 0 & 0 & 2 & 0.33 \\
\hline NRWS & 0 & 0 & 0 & 0 & 0 & 1 & 0 & 0 & 0 & 0 & 1 & 0.17 \\
\hline BUSH & 5 & 1 & 24 & 5 & 2 & 32 & 17 & 8 & 4 & 0 & 98 & 16.33 \\
\hline BEWR & 1 & 0 & 7 & 2 & 0 & 4 & 1 & 1 & 1 & 0 & 17 & 2.83 \\
\hline HOWR & 2 & 2 & 2 & 5 & 4 & 4 & 0 & 0 & 3 & 1 & 23 & 3.83 \\
\hline SWTH & 2 & 10 & 3 & 0 & 0 & 0 & 1 & 0 & 0 & 0 & 16 & 2.67 \\
\hline WREN & 2 & 2 & 1 & 6 & 5 & 5 & 2 & 1 & 2 & 1 & 27 & 4.50 \\
\hline CATH & 0 & 0 & 1 & 1 & 0 & 0 & 0 & 0 & 1 & 0 & 3 & 0.50 \\
\hline OCWA & 10 & 15 & 25 & 5 & 8 & 2 & 1 & 1 & 2 & 0 & 69 & 11.50 \\
\hline YWAR & 3 & 5 & 5 & 1 & 0 & 0 & 0 & 0 & 0 & 0 & 14 & 2.33 \\
\hline COYE & 3 & 6 & 1 & 4 & 4 & 9 & 18 & 5 & 4 & 5 & 59 & 9.83 \\
\hline WIWA & 6 & 39 & 0 & 0 & 0 & 0 & 0 & 0 & 0 & 0 & 45 & 7.50 \\
\hline $\mathrm{YBCH}$ & 1 & 3 & 1 & 0 & 2 & 3 & 1 & 0 & 0 & 2 & 13 & 2.17 \\
\hline SPTO & 1 & 1 & 0 & 0 & 2 & 0 & 1 & 0 & 0 & 0 & 5 & 0.83 \\
\hline CALT & 0 & 0 & 2 & 1 & 0 & 2 & 0 & 0 & 0 & 1 & 6 & 1.00 \\
\hline SOSP & 9 & 3 & 3 & 5 & 11 & 9 & 7 & 5 & 5 & 7 & 64 & 10.67 \\
\hline WCSP & 1 & 0 & 0 & 0 & 0 & 0 & 0 & 0 & 0 & 0 & 1 & 0.17 \\
\hline LAZB & 0 & 0 & 1 & 0 & 0 & 0 & 0 & 0 & 0 & 0 & 1 & 0.17 \\
\hline HOFI & 0 & 0 & 0 & 0 & 2 & 0 & 1 & 0 & 0 & 0 & 3 & 0.50 \\
\hline LEGO & 0 & 0 & 0 & 0 & 0 & 0 & 0 & 0 & 0 & 1 & 1 & 0.17 \\
\hline AMGO & 0 & 1 & 0 & 4 & 0 & 0 & 0 & 0 & 0 & 0 & 5 & 0.83 \\
\hline $\begin{array}{c}\text { Captures per } \\
\text { day }\end{array}$ & 53 & 97 & 84 & 44 & 47 & 77 & 55 & 23 & 26 & 22 & 528 & 88.00 \\
\hline Total species & 19 & 16 & 16 & 14 & 13 & 13 & 14 & 8 & 11 & 10 & 30 & 5.00 \\
\hline
\end{tabular}


Table B5. Number of captures by Monitoring Avian Productivity and Survivorship (MAPS) period and date at Naval Outlying Landing Field, Imperial Beach, 2011.

[Species: See appendix A for common and scientific names]

\begin{tabular}{|c|c|c|c|c|c|c|c|c|c|c|c|c|}
\hline \multirow[b]{4}{*}{ Species } & \multicolumn{10}{|c|}{ MAPS period } & \multirow[b]{4}{*}{ Total } & \multirow{4}{*}{$\begin{array}{c}\text { Captures } \\
\text { per } 100 \\
\text { net-hours } \\
(600: 00: 00 \\
\text { total net- } \\
\text { hours) } \\
\end{array}$} \\
\hline & 1 & 2 & 3 & 4 & 5 & 6 & 7 & 8 & 9 & 10 & & \\
\hline & \multicolumn{10}{|c|}{ Date } & & \\
\hline & 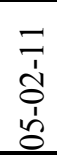 & $\begin{array}{l}= \\
\text { I } \\
\overline{1} \\
\stackrel{2}{0}\end{array}$ & $\begin{array}{l}= \\
\text { ㄱ. } \\
\stackrel{1}{1} \\
\stackrel{2}{0}\end{array}$ & $\begin{array}{l}= \\
1 \\
0 \\
0 \\
1 \\
0\end{array}$ & $\begin{array}{l}\overline{7} \\
\dot{n} \\
\dot{b}\end{array}$ & 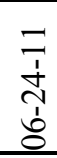 & $\begin{array}{l}= \\
1 \\
0 \\
1 \\
1 \\
0\end{array}$ & $\begin{array}{l}= \\
\stackrel{1}{1} \\
\frac{1}{0}\end{array}$ & $\begin{array}{l}\overline{1} \\
\frac{1}{1} \\
\frac{1}{0}\end{array}$ & $\begin{array}{l}= \\
\overline{1} \\
\hat{o} \\
1 \\
0 \\
0\end{array}$ & & \\
\hline $\mathrm{COHA}$ & 0 & 0 & 0 & 0 & 0 & 0 & 1 & 0 & 0 & 0 & 1 & 0.17 \\
\hline $\mathrm{BCHU}$ & 0 & 1 & 0 & 0 & 1 & 2 & 0 & 0 & 0 & 0 & 4 & 0.67 \\
\hline ANHU & 3 & 1 & 1 & 0 & 1 & 0 & 1 & 0 & 1 & 0 & 8 & 1.33 \\
\hline NUWO & 0 & 0 & 1 & 0 & 0 & 0 & 0 & 0 & 0 & 0 & 1 & 0.17 \\
\hline DOWO & 0 & 0 & 0 & 1 & 0 & 0 & 0 & 0 & 2 & 1 & 4 & 0.67 \\
\hline WIFL & 0 & 0 & 2 & 1 & 0 & 0 & 0 & 0 & 0 & 0 & 3 & 0.50 \\
\hline HAFL & 0 & 1 & 0 & 0 & 0 & 0 & 0 & 0 & 0 & 0 & 1 & 0.17 \\
\hline PSFL & 0 & 0 & 1 & 0 & 6 & 1 & 0 & 2 & 0 & 0 & 10 & 1.67 \\
\hline ATFL & 0 & 0 & 0 & 1 & 1 & 0 & 0 & 0 & 0 & 0 & 2 & 0.33 \\
\hline LBVI & 1 & 2 & 2 & 0 & 1 & 2 & 0 & 4 & 1 & 4 & 17 & 2.83 \\
\hline HUVI & 0 & 0 & 0 & 0 & 3 & 0 & 0 & 0 & 2 & 0 & 5 & 0.83 \\
\hline WAVI & 2 & 3 & 5 & 0 & 0 & 0 & 0 & 0 & 0 & 0 & 10 & 1.67 \\
\hline BUSH & 2 & 2 & 9 & 2 & 15 & 9 & 2 & 6 & 16 & 26 & 89 & 14.83 \\
\hline BEWR & 1 & 1 & 1 & 2 & 2 & 1 & 2 & 1 & 0 & 0 & 11 & 1.83 \\
\hline HOWR & 0 & 0 & 2 & 3 & 0 & 2 & 2 & 1 & 1 & 0 & 11 & 1.83 \\
\hline SWTH & 0 & 12 & 3 & 1 & 0 & 0 & 0 & 0 & 0 & 0 & 16 & 2.67 \\
\hline WREN & 2 & 1 & 2 & 2 & 1 & 0 & 3 & 0 & 0 & 0 & 11 & 1.83 \\
\hline OCWA & 11 & 6 & 1 & 3 & 2 & 1 & 2 & 0 & 0 & 0 & 26 & 4.33 \\
\hline NAWA & 3 & 0 & 0 & 0 & 0 & 0 & 0 & 0 & 0 & 0 & 3 & 0.50 \\
\hline YWAR & 1 & 2 & 2 & 0 & 0 & 2 & 0 & 0 & 0 & 0 & 7 & 1.17 \\
\hline TOWA & 0 & 1 & 0 & 0 & 0 & 0 & 0 & 0 & 0 & 0 & 1 & 0.17 \\
\hline MGWA & 1 & 0 & 0 & 0 & 0 & 0 & 0 & 0 & 0 & 0 & 1 & 0.17 \\
\hline COYE & 8 & 5 & 4 & 4 & 5 & 5 & 5 & 5 & 2 & 3 & 46 & 7.67 \\
\hline WIWA & 19 & 10 & 5 & 1 & 0 & 0 & 0 & 0 & 0 & 0 & 35 & 5.83 \\
\hline $\mathrm{YBCH}$ & 2 & 0 & 1 & 2 & 0 & 0 & 0 & 0 & 0 & 0 & 5 & 0.83 \\
\hline SPTO & 0 & 0 & 1 & 0 & 0 & 0 & 1 & 0 & 0 & 1 & 3 & 0.50 \\
\hline CALT & 0 & 0 & 0 & 1 & 0 & 0 & 0 & 0 & 0 & 1 & 2 & 0.33 \\
\hline SOSP & 5 & 5 & 7 & 10 & 14 & 12 & 3 & 7 & 5 & 5 & 73 & 12.17 \\
\hline WCSP & 1 & 0 & 0 & 0 & 0 & 0 & 0 & 0 & 0 & 0 & 1 & 0.17 \\
\hline GCSP & 1 & 0 & 0 & 0 & 0 & 0 & 0 & 0 & 0 & 0 & 1 & 0.17 \\
\hline NOCA & 0 & 1 & 0 & 0 & 0 & 0 & 0 & 0 & 0 & 0 & 1 & 0.17 \\
\hline HOFI & 0 & 0 & 0 & 0 & 0 & 0 & 0 & 0 & 0 & 6 & 6 & 1.00 \\
\hline AMGO & 0 & 0 & 0 & 0 & 4 & 2 & 0 & 2 & 2 & 0 & 10 & 1.67 \\
\hline Captures per day & 63 & 54 & 50 & 34 & 56 & 39 & 22 & 28 & 32 & 47 & 425 & 70.83 \\
\hline Total species ${ }^{1}$ & 16 & 16 & 18 & 14 & 13 & 11 & 10 & 8 & 9 & 8 & 33 & 5.50 \\
\hline
\end{tabular}

${ }^{1}$ Unidentified species not included in species total. 
TableB6. Number of captures by Monitoring Avian Productivity and Survivorship (MAPS) period and date at Naval Outlying Landing Field, Imperial Beach, 2012.

[Species: See appendix A for common and scientific names]

\begin{tabular}{|c|c|c|c|c|c|c|c|c|c|c|c|c|c|c|c|}
\hline \multirow[b]{4}{*}{ Species } & \multicolumn{13}{|c|}{ MAPS period } & \multirow[b]{4}{*}{ Total } & \multirow[b]{4}{*}{$\begin{array}{c}\text { Captures } \\
\text { per } 100 \\
\text { net-hours } \\
\text { (764:00 tota } \\
\text { net-hours) }\end{array}$} \\
\hline & -3 & -2 & -1 & 1 & 2 & 3 & 4 & 5 & 6 & 7 & 8 & 9 & 10 & & \\
\hline & \multicolumn{13}{|c|}{ Date } & & \\
\hline & $\begin{array}{l}N \\
\stackrel{1}{1} \\
\stackrel{0}{0} \\
\dot{1} \\
\dot{0}\end{array}$ & $\begin{array}{l}\stackrel{N}{1} \\
\stackrel{1}{1} \\
\dot{J} \\
0\end{array}$ & 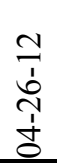 & 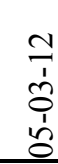 & $\frac{N}{1}$ & 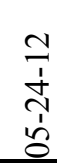 & $\begin{array}{l}1 \\
1 \\
0 \\
1 \\
0\end{array}$ & $\begin{array}{l}\frac{1}{J} \\
\dot{J} \\
\dot{1} \\
0\end{array}$ & $\begin{array}{l}\sim \\
1 \\
\infty \\
⿱ 1 \\
1 \\
0\end{array}$ & \begin{tabular}{l}
$N$ \\
\multirow{1}{1}{} \\
$\hat{1}$ \\
1 \\
$\hat{0}$
\end{tabular} & $\frac{N}{1}$ & 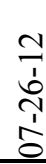 & $\begin{array}{l}\text { N } \\
\text { ป̀ } \\
0 \\
1 \\
0 \\
0\end{array}$ & & \\
\hline COGD & 0 & 0 & 0 & 1 & 0 & 0 & 0 & 0 & 0 & 1 & 0 & 0 & 0 & 2 & 0.26 \\
\hline $\mathrm{BCHU}$ & 0 & 1 & 2 & 0 & 1 & 0 & 0 & 0 & 0 & 0 & 0 & 0 & 0 & 4 & 0.52 \\
\hline ANHU & 3 & 1 & 7 & 3 & 1 & 1 & 2 & 1 & 3 & 0 & 1 & 0 & 2 & 25 & 3.27 \\
\hline CAHU & 0 & 0 & 0 & 1 & 0 & 0 & 0 & 0 & 0 & 0 & 0 & 0 & 0 & 1 & 0.13 \\
\hline RUHU & 1 & 1 & 0 & 0 & 1 & 0 & 0 & 0 & 0 & 0 & 0 & 0 & 0 & 3 & 0.39 \\
\hline ALHU & 0 & 1 & 0 & 0 & 0 & 0 & 0 & 0 & 0 & 0 & 1 & 0 & 1 & 3 & 0.39 \\
\hline USHU & 1 & 0 & 0 & 0 & 0 & 0 & 0 & 0 & 0 & 0 & 0 & 0 & 0 & 1 & 0.13 \\
\hline NUWO & 0 & 0 & 0 & 0 & 0 & 0 & 2 & 1 & 0 & 0 & 0 & 0 & 0 & 3 & 0.39 \\
\hline DOWO & 0 & 0 & 1 & 0 & 2 & 0 & 0 & 1 & 5 & 1 & 0 & 1 & 0 & 11 & 1.44 \\
\hline WIFL & 0 & 0 & 0 & 0 & 0 & 0 & 0 & 1 & 0 & 0 & 0 & 0 & 0 & 1 & 0.13 \\
\hline PSFL & 0 & 0 & 1 & 4 & 1 & 0 & 2 & 0 & 0 & 2 & 0 & 0 & 0 & 10 & 1.31 \\
\hline BLPH & 0 & 0 & 0 & 0 & 0 & 1 & 0 & 0 & 0 & 0 & 0 & 0 & 0 & 1 & 0.13 \\
\hline ATFL & 0 & 0 & 5 & 0 & 0 & 0 & 0 & 0 & 0 & 0 & 0 & 0 & 1 & 6 & 0.79 \\
\hline LBVI & 2 & 0 & 1 & 0 & 0 & 0 & 1 & 1 & 0 & 0 & 0 & 0 & 0 & 5 & 0.65 \\
\hline HUVI & 0 & 0 & 0 & 0 & 1 & 0 & 0 & 2 & 1 & 0 & 2 & 1 & 1 & 8 & 1.05 \\
\hline WAVI & 0 & 0 & 0 & 2 & 3 & 0 & 0 & 0 & 0 & 0 & 0 & 0 & 0 & 5 & 0.65 \\
\hline TRES & 0 & 0 & 0 & 0 & 0 & 0 & 1 & 0 & 0 & 0 & 0 & 0 & 0 & 1 & 0.13 \\
\hline CLSW & 0 & 0 & 0 & 0 & 0 & 0 & 7 & 0 & 0 & 0 & 0 & 0 & 0 & 7 & 0.92 \\
\hline BUSH & 3 & 4 & 2 & 1 & 29 & 9 & 4 & 10 & 17 & 5 & 11 & 2 & 32 & 129 & 16.88 \\
\hline BEWR & 1 & 1 & 2 & 2 & 2 & 1 & 1 & 2 & 1 & 3 & 1 & 1 & 1 & 19 & 2.49 \\
\hline HOWR & 5 & 0 & 1 & 5 & 4 & 2 & 3 & 5 & 1 & 1 & 0 & 0 & 0 & 27 & 3.53 \\
\hline SWTH & 0 & 0 & 1 & 4 & 4 & 1 & 1 & 0 & 0 & 0 & 0 & 0 & 0 & 11 & 1.44 \\
\hline HETH & 4 & 1 & 0 & 0 & 0 & 0 & 0 & 0 & 0 & 0 & 0 & 0 & 0 & 5 & 0.65 \\
\hline WREN & 1 & 2 & 2 & 5 & 1 & 1 & 3 & 4 & 0 & 2 & 3 & 0 & 1 & 25 & 3.27 \\
\hline CATH & 0 & 0 & 1 & 1 & 0 & 0 & 0 & 0 & 0 & 0 & 0 & 0 & 0 & 2 & 0.26 \\
\hline OCWA & 13 & 7 & 10 & 11 & 12 & 10 & 3 & 2 & 0 & 1 & 0 & 0 & 4 & 73 & 9.55 \\
\hline YWAR & 0 & 0 & 2 & 2 & 9 & 2 & 1 & 1 & 0 & 2 & 1 & 0 & 0 & 20 & 2.62 \\
\hline AUWA & 8 & 1 & 1 & 0 & 0 & 0 & 0 & 0 & 0 & 0 & 0 & 0 & 0 & 10 & 1.31 \\
\hline TOWA & 0 & 0 & 0 & 1 & 0 & 0 & 0 & 0 & 0 & 0 & 0 & 0 & 0 & 1 & 0.13 \\
\hline HEWA & 0 & 0 & 1 & 0 & 0 & 0 & 0 & 0 & 0 & 0 & 0 & 0 & 0 & 1 & 0.13 \\
\hline COYE & 15 & 2 & 6 & 7 & 11 & 7 & 11 & 15 & 9 & 4 & 4 & 0 & 5 & 96 & 12.57 \\
\hline WIWA & 0 & 0 & 9 & 12 & 4 & 0 & 0 & 0 & 0 & 0 & 0 & 0 & 0 & 25 & 3.27 \\
\hline YBCH & 0 & 3 & 1 & 3 & 1 & 0 & 1 & 0 & 0 & 0 & 0 & 0 & 0 & 9 & 1.18 \\
\hline SPTO & 2 & 0 & 1 & 0 & 1 & 0 & 1 & 1 & 0 & 0 & 1 & 0 & 0 & 7 & 0.92 \\
\hline CALT & 0 & 0 & 0 & 1 & 1 & 0 & 0 & 1 & 1 & 1 & 0 & 0 & 1 & 6 & 0.79 \\
\hline SOSP & 7 & 6 & 3 & 9 & 10 & 6 & 5 & 17 & 9 & 6 & 1 & 9 & 8 & 96 & 12.57 \\
\hline LISP & 1 & 3 & 0 & 0 & 0 & 0 & 0 & 0 & 0 & 0 & 0 & 0 & 0 & 4 & 0.52 \\
\hline
\end{tabular}




\begin{tabular}{|c|c|c|c|c|c|c|c|c|c|c|c|c|c|c|c|}
\hline \multirow[b]{4}{*}{ Species } & \multicolumn{13}{|c|}{ MAPS period } & \multirow[b]{4}{*}{ Total } & \multirow[b]{4}{*}{$\begin{array}{c}\text { Captures } \\
\text { per } 100 \\
\text { net-hours } \\
\text { (764:00 tota } \\
\text { net-hours) } \\
\end{array}$} \\
\hline & -3 & -2 & -1 & 1 & 2 & 3 & 4 & 5 & 6 & 7 & 8 & 9 & 10 & & \\
\hline & \multicolumn{13}{|c|}{ Date } & & \\
\hline & $\begin{array}{l}1 \\
1 \\
2 \\
1 \\
\vdots \\
0\end{array}$ & $\begin{array}{l}\frac{1}{1} \\
\stackrel{1}{I} \\
\dot{d}\end{array}$ & 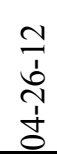 & $\begin{array}{l}\sim \\
1 \\
\hat{o} \\
1 \\
0 \\
0\end{array}$ & $\frac{\frac{1}{1}}{\frac{1}{2}}$ & $\begin{array}{l}\stackrel{1}{7} \\
\stackrel{+}{1} \\
\stackrel{2}{0}\end{array}$ & $\begin{array}{l}1 \\
1 \\
1 \\
1 \\
0 \\
0\end{array}$ & $\frac{7}{\frac{1}{d}}$ & 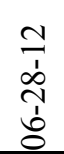 & $\begin{array}{l}\frac{N}{1} \\
\frac{1}{0} \\
1 \\
0\end{array}$ & $\frac{\frac{1}{1}}{\frac{1}{1}}$ & $\begin{array}{l}\frac{1}{1} \\
\text { o } \\
\frac{1}{0}\end{array}$ & $\begin{array}{l}\text { I } \\
\text { ḋ } \\
0 \\
1 \\
0 \\
0\end{array}$ & & \\
\hline WCSP & 8 & 10 & 2 & 0 & 0 & 0 & 0 & 0 & 0 & 0 & 0 & 0 & 0 & 20 & 2.62 \\
\hline GCSP & 2 & 1 & 0 & 0 & 0 & 0 & 0 & 0 & 0 & 0 & 0 & 0 & 0 & 3 & 0.39 \\
\hline BHGR & 0 & 0 & 1 & 0 & 1 & 0 & 0 & 0 & 0 & 0 & 0 & 0 & 0 & 2 & 0.26 \\
\hline HOFI & 1 & 1 & 0 & 0 & 0 & 0 & 0 & 0 & 0 & 0 & 7 & 12 & 3 & 24 & 3.14 \\
\hline LEGO & 0 & 0 & 1 & 0 & 1 & 0 & 0 & 0 & 0 & 0 & 0 & 0 & 0 & 2 & 0.26 \\
\hline LAGO & 1 & 2 & 0 & 0 & 0 & 0 & 0 & 0 & 0 & 0 & 0 & 0 & 0 & 3 & 0.39 \\
\hline AMGO & 0 & 0 & 1 & 1 & 0 & 1 & 0 & 0 & 1 & 0 & 0 & 0 & 1 & 5 & 0.65 \\
\hline $\begin{array}{c}\text { Captures } \\
\text { per day }\end{array}$ & 79 & 48 & 65 & 76 & 101 & 42 & 49 & 65 & 48 & 29 & 33 & 26 & 61 & 722 & 94.50 \\
\hline $\begin{array}{l}\text { Total } \\
\text { species }^{1}\end{array}$ & 18 & 18 & 25 & 20 & 22 & 12 & 17 & 16 & 10 & 12 & 11 & 6 & 13 & 43 & 5.63 \\
\hline
\end{tabular}

${ }^{1}$ Unidentified species not included in species total. 
Table B7. Number of captures by Monitoring Avian Productivity and Survivorship (MAPS) period and date at Naval Outlying Landing Field, Imperial Beach, 2013.

[Species: See appendix A for common and scientific names]

\begin{tabular}{|c|c|c|c|c|c|c|c|c|c|c|c|c|c|c|c|}
\hline \multirow[b]{4}{*}{ Species } & \multicolumn{13}{|c|}{ MAPS period } & \multirow[b]{4}{*}{ Total } & \multirow{4}{*}{$\begin{array}{c}\text { Captures } \\
\text { per } 100 \\
\text { Net- } \\
\text { hours } \\
\text { (783:00 } \\
\text { total net- } \\
\text { hours) } \\
\end{array}$} \\
\hline & -3 & -2 & -1 & 1 & 2 & 3 & 4 & 5 & 6 & 7 & 8 & 9 & 10 & & \\
\hline & \multicolumn{13}{|c|}{ Date } & & \\
\hline & $\begin{array}{l}\frac{m}{\dot{d}} \\
\dot{d} \\
\dot{d}\end{array}$ & $\frac{m}{\frac{m}{\sigma}}$ & $\underset{\stackrel{\oplus}{\dot{d}}}{\stackrel{m}{\delta}}$ & $\begin{array}{l}\stackrel{m}{\grave{\delta}} \\
\text { ঠे }\end{array}$ & $\frac{m}{\frac{m}{6}}$ & $\underset{\text { ஸे }}{\stackrel{m}{\circ}}$ & $\begin{array}{l}\text { m } \\
\text { த் } \\
\dot{0}\end{array}$ & $\frac{m}{\dot{m}}$ & 官 & 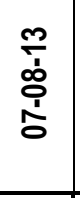 & $\frac{m}{\frac{m}{\sigma}}$ & $\frac{m}{\stackrel{N}{N}}$ & $\begin{array}{l}\frac{m}{1} \\
\frac{1}{0} \\
\text { o }\end{array}$ & & \\
\hline COGD & 0 & 0 & 0 & 0 & 0 & 0 & 1 & 0 & 0 & 0 & 0 & 0 & 2 & 3 & 0.38 \\
\hline $\mathrm{BCHU}$ & 0 & 0 & 4 & 1 & 0 & 0 & 0 & 0 & 0 & 0 & 0 & 0 & 0 & 5 & 0.64 \\
\hline ANHU & 2 & 2 & 5 & 0 & 6 & 2 & 1 & 3 & 6 & 3 & 1 & 2 & 0 & 33 & 4.21 \\
\hline CAHU & 0 & 0 & 2 & 0 & 0 & 0 & 0 & 0 & 0 & 0 & 0 & 0 & 0 & 2 & 0.26 \\
\hline RUHU & 2 & 0 & 0 & 0 & 0 & 0 & 0 & 0 & 0 & 0 & 1 & 0 & 0 & 3 & 0.38 \\
\hline ALHU & 0 & 0 & 0 & 0 & 0 & 0 & 0 & 0 & 0 & 0 & 0 & 0 & 1 & 1 & 0.13 \\
\hline NUWO & 0 & 0 & 0 & 1 & 0 & 0 & 0 & 0 & 0 & 0 & 0 & 1 & 0 & 2 & 0.26 \\
\hline DOWO & 0 & 0 & 0 & 1 & 0 & 0 & 1 & 0 & 1 & 1 & 0 & 0 & 1 & 5 & 0.64 \\
\hline WIFL & 0 & 0 & 0 & 0 & 0 & 1 & 2 & 0 & 0 & 0 & 0 & 0 & 0 & 3 & 0.38 \\
\hline PSFL & 0 & 0 & 1 & 3 & 3 & 1 & 0 & 0 & 0 & 0 & 1 & 0 & 0 & 9 & 1.15 \\
\hline ATFL & 2 & 2 & 0 & 0 & 0 & 0 & 0 & 0 & 1 & 0 & 0 & 0 & 0 & 5 & 0.64 \\
\hline LBVI & 1 & 1 & 0 & 1 & 1 & 0 & 0 & 1 & 3 & 3 & 0 & 0 & 1 & 12 & 1.53 \\
\hline HUVI & 0 & 0 & 1 & 0 & 0 & 0 & 0 & 0 & 0 & 1 & 0 & 1 & 0 & 3 & 0.38 \\
\hline WAVI & 0 & 0 & 1 & 1 & 2 & 2 & 0 & 0 & 0 & 0 & 0 & 0 & 0 & 6 & 0.77 \\
\hline REVI & 0 & 0 & 0 & 0 & 0 & 0 & 1 & 0 & 0 & 0 & 0 & 0 & 0 & 1 & 0.13 \\
\hline NRWS & 0 & 0 & 0 & 0 & 0 & 1 & 0 & 0 & 0 & 0 & 0 & 0 & 0 & 1 & 0.13 \\
\hline BUSH & 7 & 0 & 1 & 3 & 15 & 14 & 10 & 5 & 6 & 1 & 7 & 9 & 8 & 86 & 10.98 \\
\hline BEWR & 0 & 1 & 1 & 1 & 1 & 0 & 3 & 1 & 0 & 2 & 1 & 2 & 2 & 15 & 1.92 \\
\hline HOWR & 6 & 0 & 1 & 2 & 4 & 2 & 2 & 1 & 1 & 3 & 3 & 0 & 1 & 26 & 3.32 \\
\hline SWTH & 0 & 0 & 0 & 1 & 2 & 4 & 0 & 0 & 0 & 0 & 0 & 0 & 0 & 7 & 0.89 \\
\hline HETH & 1 & 1 & 0 & 0 & 0 & 0 & 0 & 0 & 0 & 0 & 0 & 0 & 0 & 2 & 0.26 \\
\hline WREN & 1 & 2 & 0 & 1 & 1 & 1 & 0 & 3 & 5 & 1 & 0 & 0 & 0 & 15 & 1.92 \\
\hline $\mathrm{CATH}$ & 0 & 0 & 0 & 1 & 0 & 0 & 0 & 0 & 1 & 1 & 0 & 0 & 0 & 3 & 0.38 \\
\hline OCWA & 21 & 26 & 11 & 6 & 15 & 9 & 2 & 1 & 0 & 1 & 1 & 3 & 4 & 100 & 12.77 \\
\hline YWAR & 0 & 0 & 0 & 1 & 1 & 2 & 1 & 2 & 0 & 0 & 0 & 0 & 0 & 7 & 0.89 \\
\hline AUWA & 0 & 2 & 0 & 0 & 0 & 0 & 0 & 0 & 0 & 0 & 0 & 0 & 0 & 2 & 0.26 \\
\hline HEWA & 0 & 0 & 1 & 1 & 0 & 0 & 0 & 0 & 0 & 0 & 0 & 0 & 0 & 2 & 0.26 \\
\hline MGWA & 0 & 1 & 1 & 1 & 0 & 0 & 0 & 0 & 0 & 0 & 0 & 0 & 0 & 3 & $\mathbf{0 . 3 8}$ \\
\hline COYE & 8 & 4 & 8 & 4 & 6 & 8 & 15 & 5 & 8 & 4 & 4 & 4 & 1 & 79 & 10.09 \\
\hline WIWA & 0 & 2 & 1 & 15 & 0 & 0 & 0 & 0 & 0 & 0 & 0 & 0 & 0 & 18 & 2.30 \\
\hline $\mathrm{YBCH}$ & 0 & 0 & 0 & 4 & 1 & 1 & 0 & 0 & 1 & 2 & 0 & 0 & 1 & 10 & 1.28 \\
\hline SPTO & 0 & 0 & 2 & 0 & 1 & 1 & 1 & 1 & 0 & 1 & 0 & 0 & 0 & 7 & 0.89 \\
\hline CALT & 0 & 0 & 1 & 0 & 0 & 0 & 0 & 0 & 0 & 2 & 2 & 1 & 0 & 6 & 0.77 \\
\hline FOSP & 0 & 1 & 0 & 0 & 0 & 0 & 0 & 0 & 0 & 0 & 0 & 0 & 0 & 1 & 0.13 \\
\hline SOSP & 7 & 3 & 5 & 2 & 8 & 18 & 22 & 12 & 11 & 16 & 5 & 11 & 3 & 123 & 15.71 \\
\hline
\end{tabular}




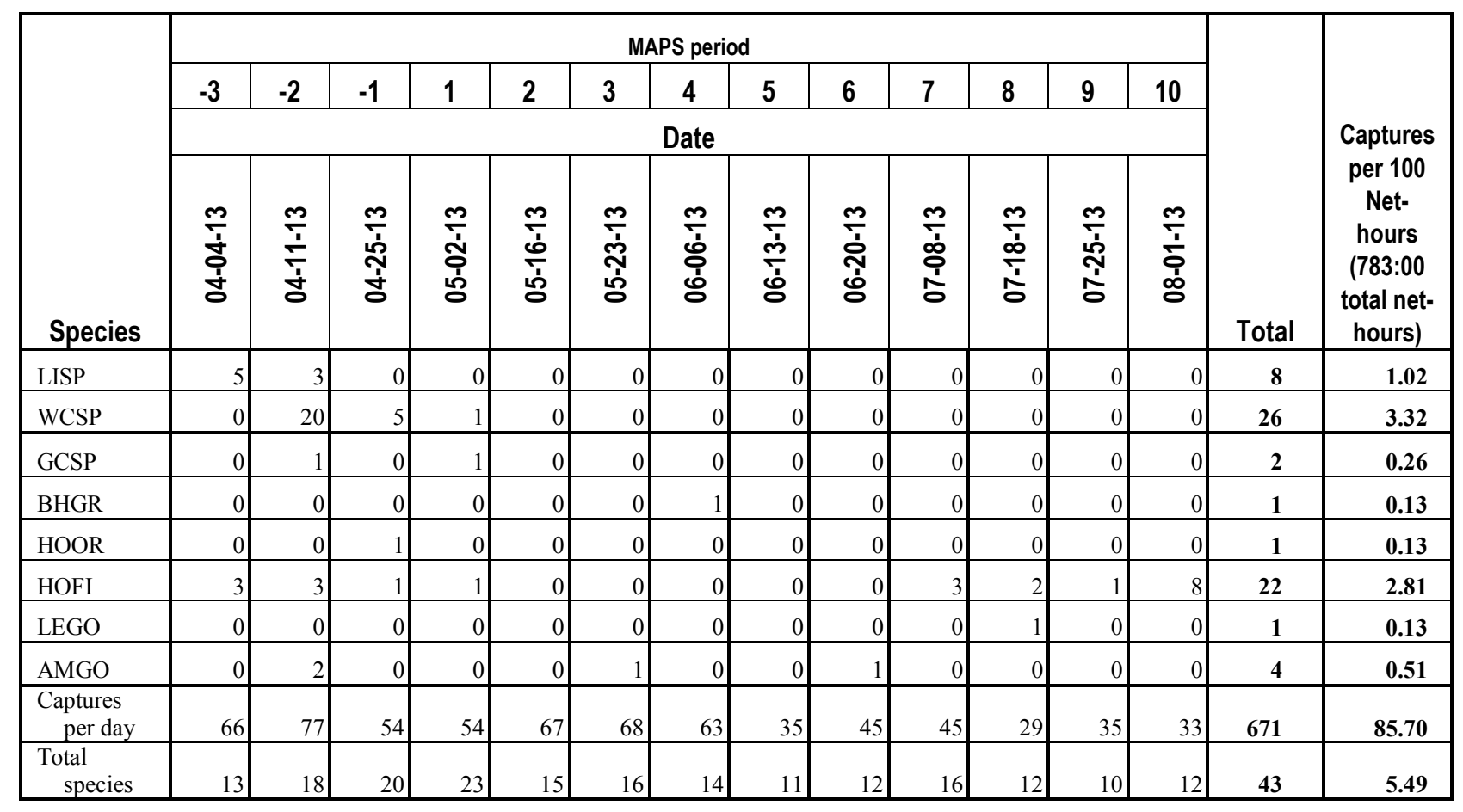




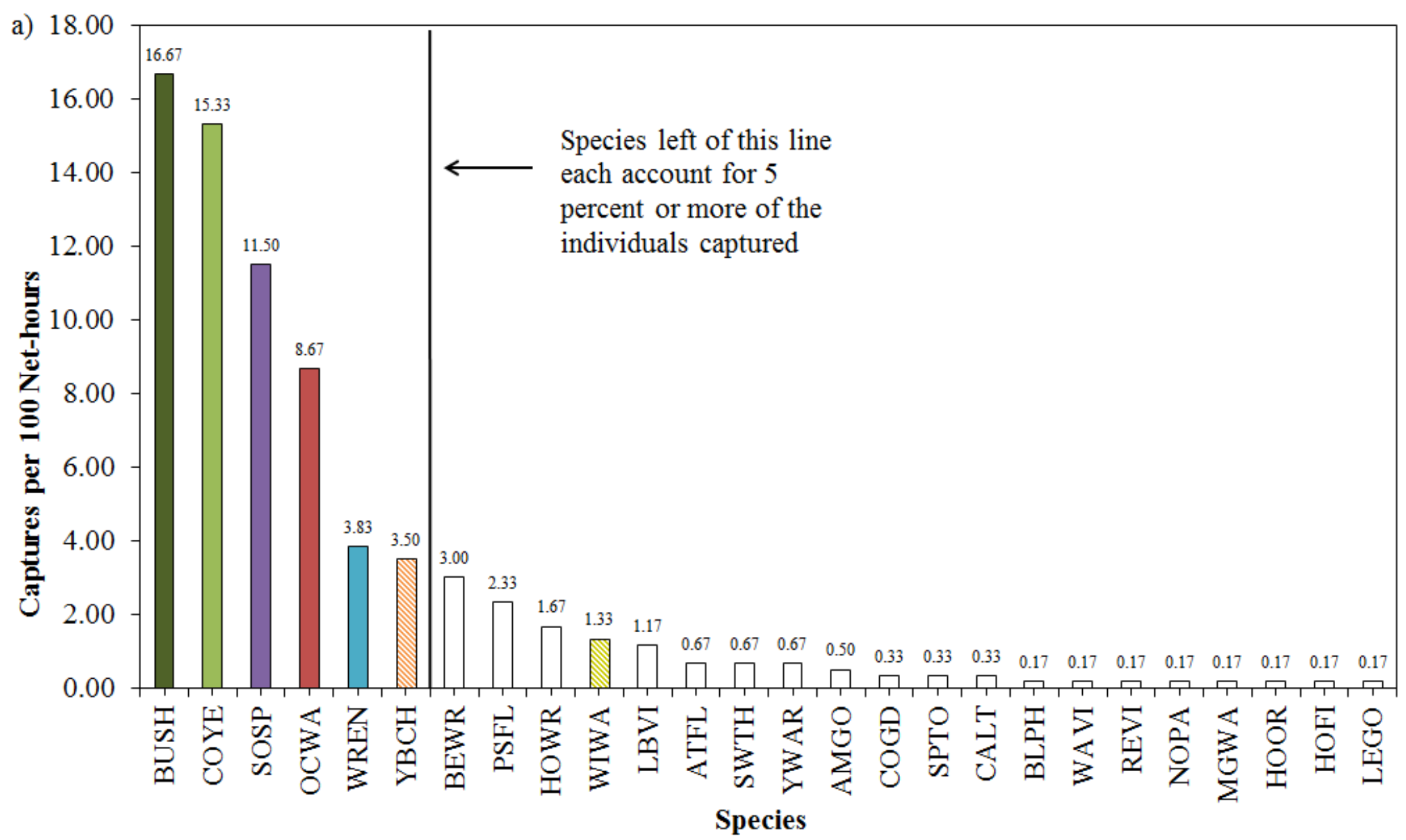

Figure B1. Number of individuals captured per species per 100 net-hours at Naval Outlying Landing Field, Imperial Beach, 2009-13. Species that accounted for 5 percent or more of the individuals captured in 1 or more years were given colored bars to track annual variation. Solid colored bars are year-round residents (including species considered Neotropical migrants under the Neotropical Migratory Bird Conservation Act of 2000), and cross-hatched bars are migratory species. Bushtit, Common Yellowthroat, Orange-crowned Warbler, and Song Sparrow each constituted more than 5 percent of the captures each year. See appendix A for common and scientific names. 
2010

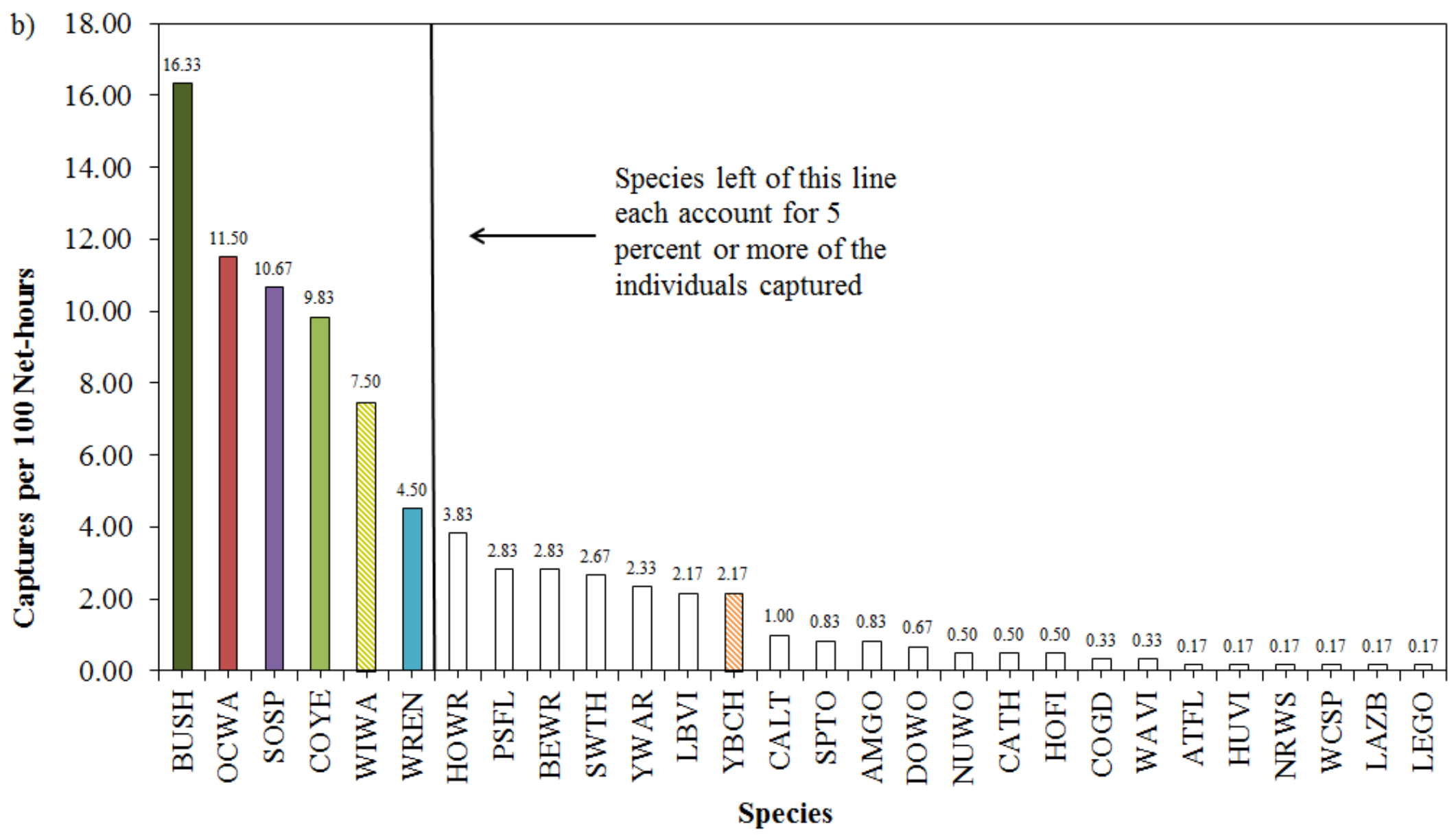

Figure B1.-Continued. 
2011

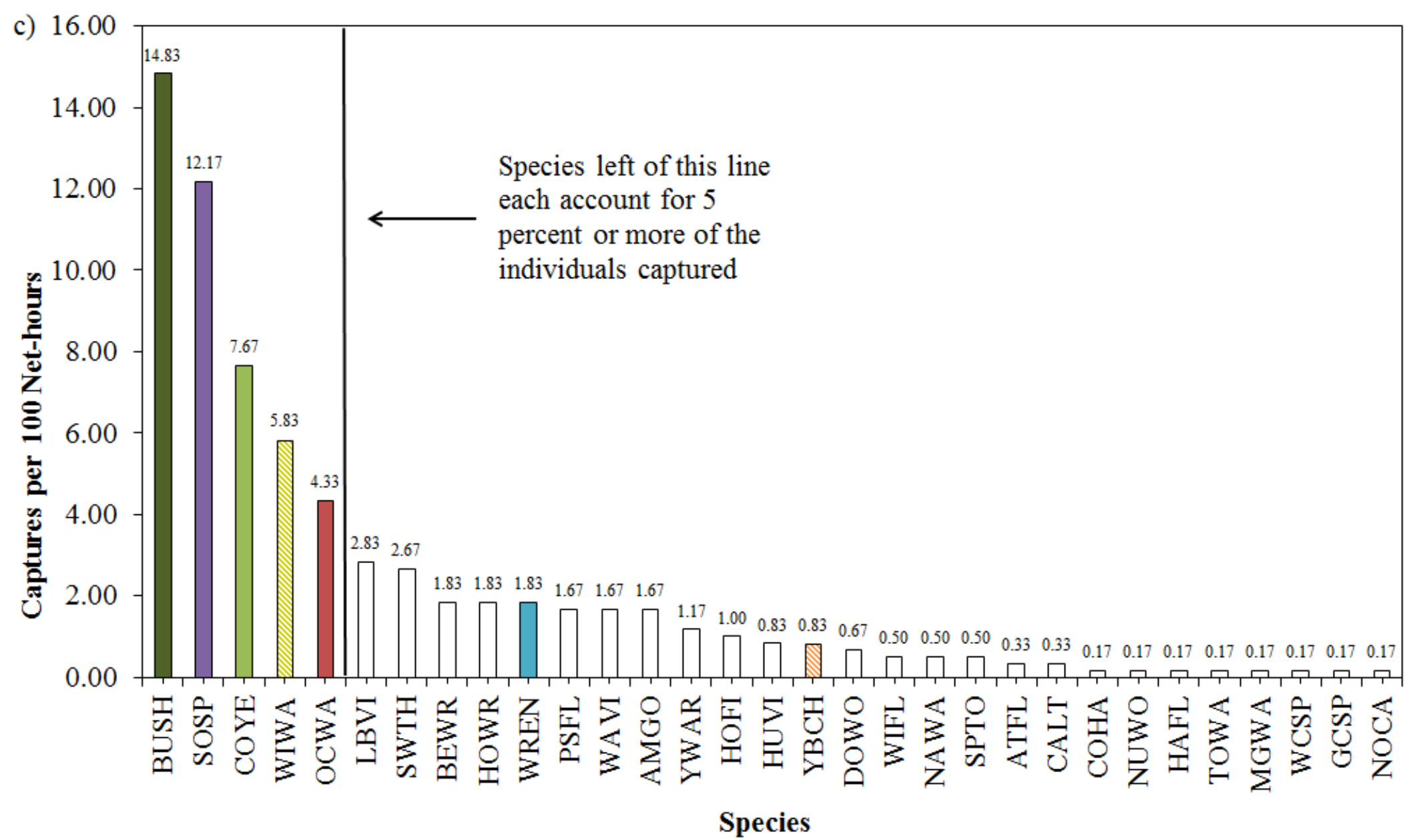

Figure B1.-Continued. 


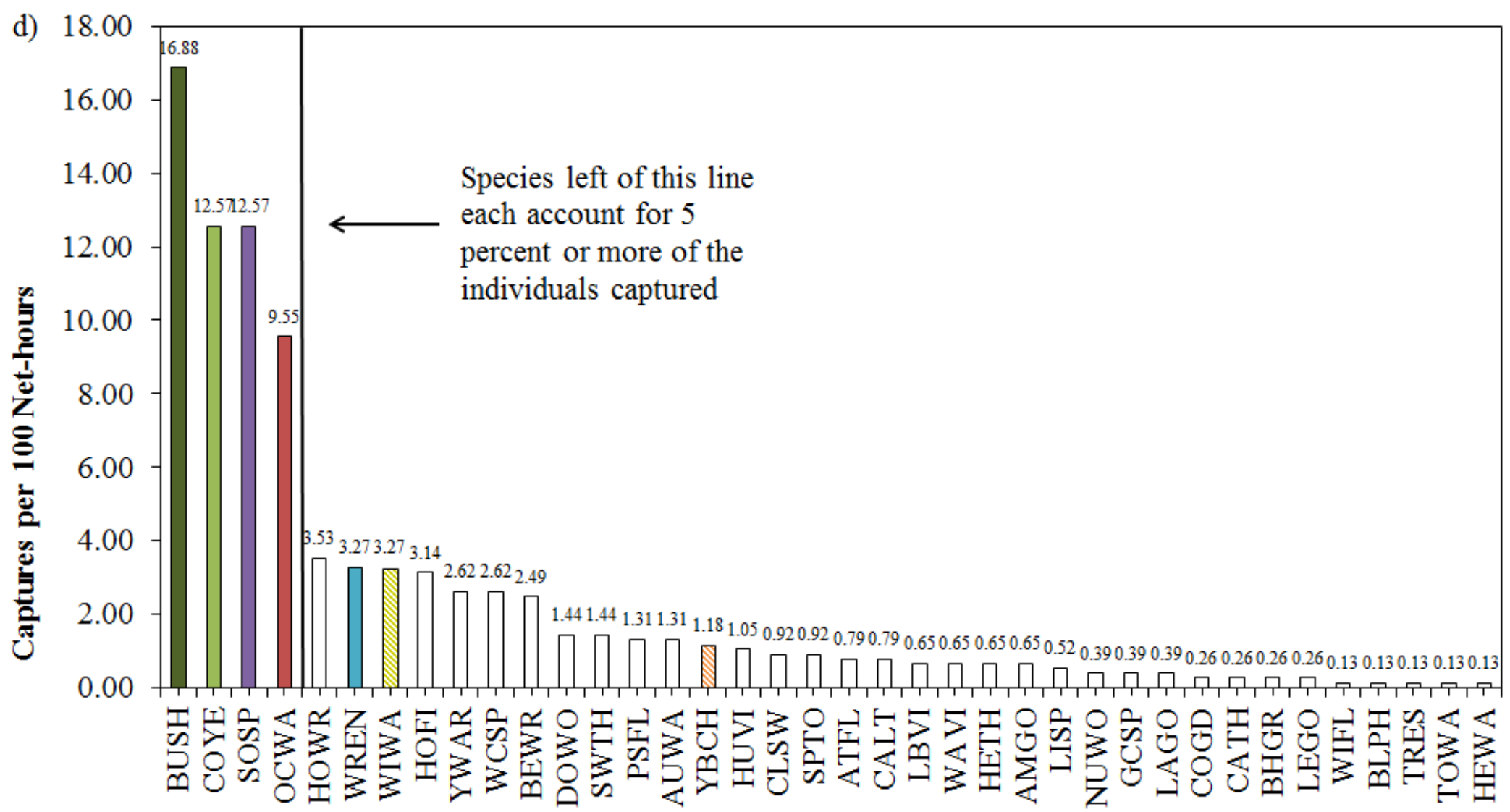

Species

Figure B1.-Continued. 


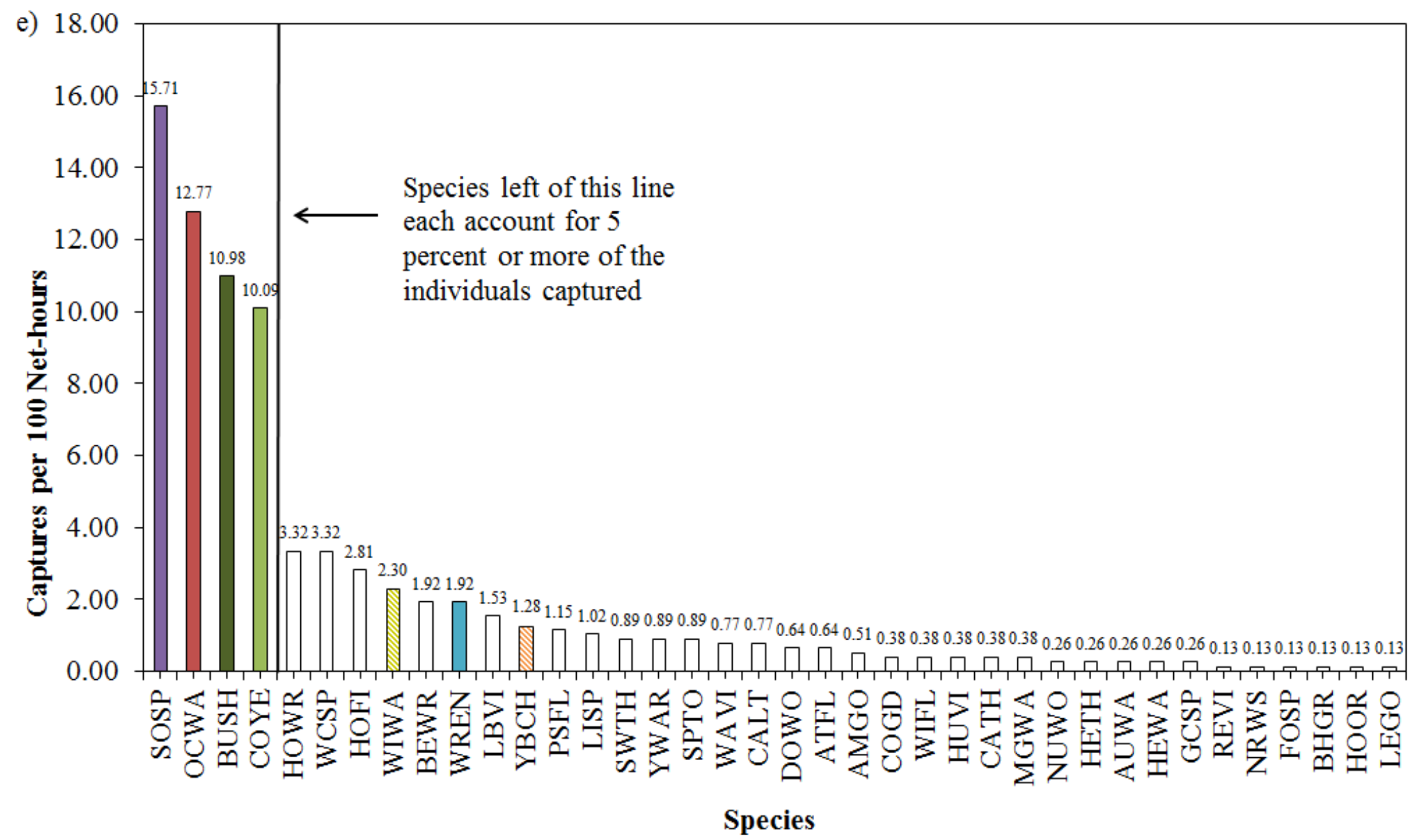

Figure B1.-Continued. 

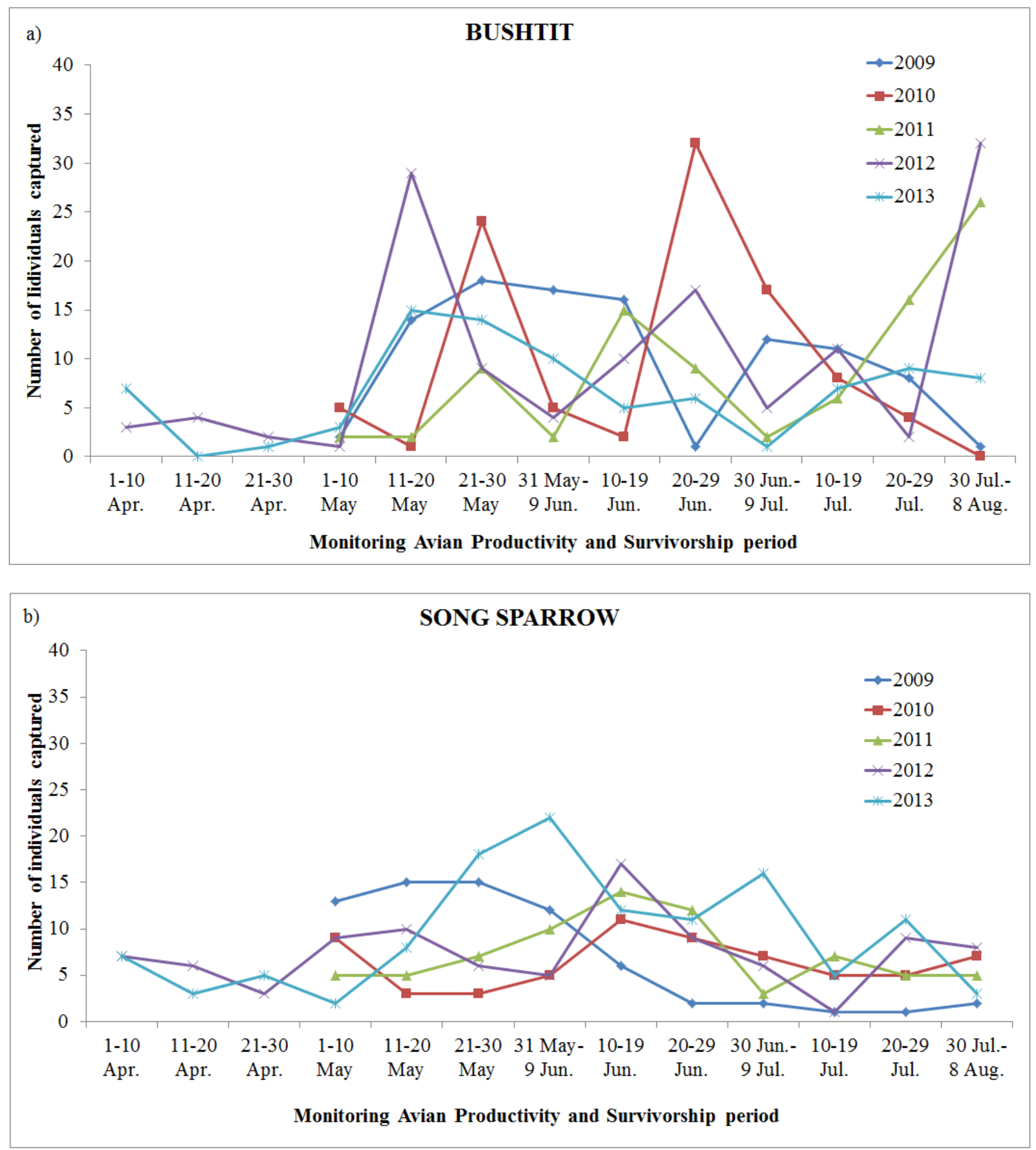

Figure B2. Seasonal and annual variation in individual captures of year-round resident species $(a-e)$ and migratory species $(f-g)$ constituting 5 percent or more of the total captures for 1 or more years at Naval Outlying Landing Field, Imperial Beach, 2009-13. See appendix A for common and scientific names. 

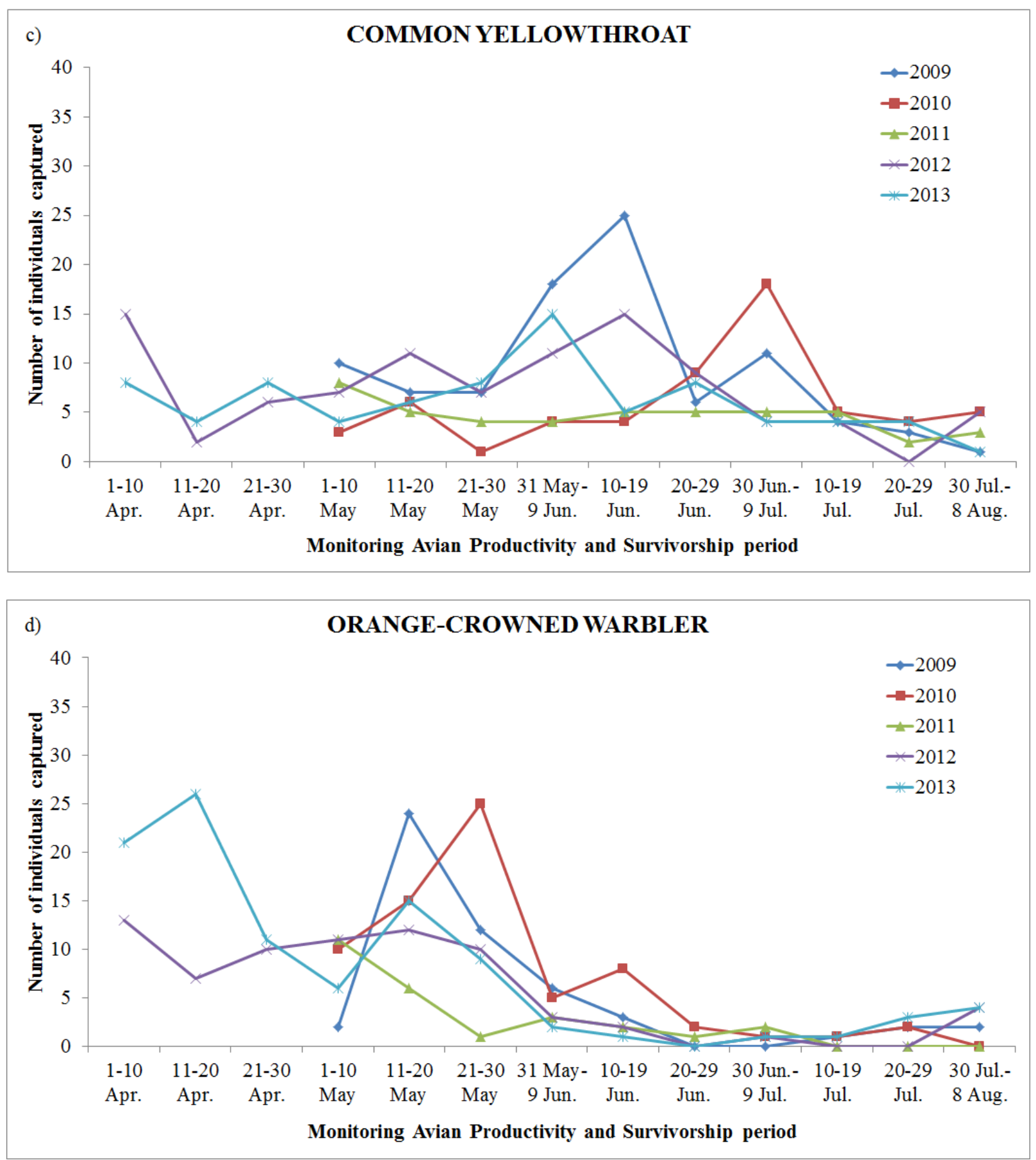

Figure B2.-Continued. 


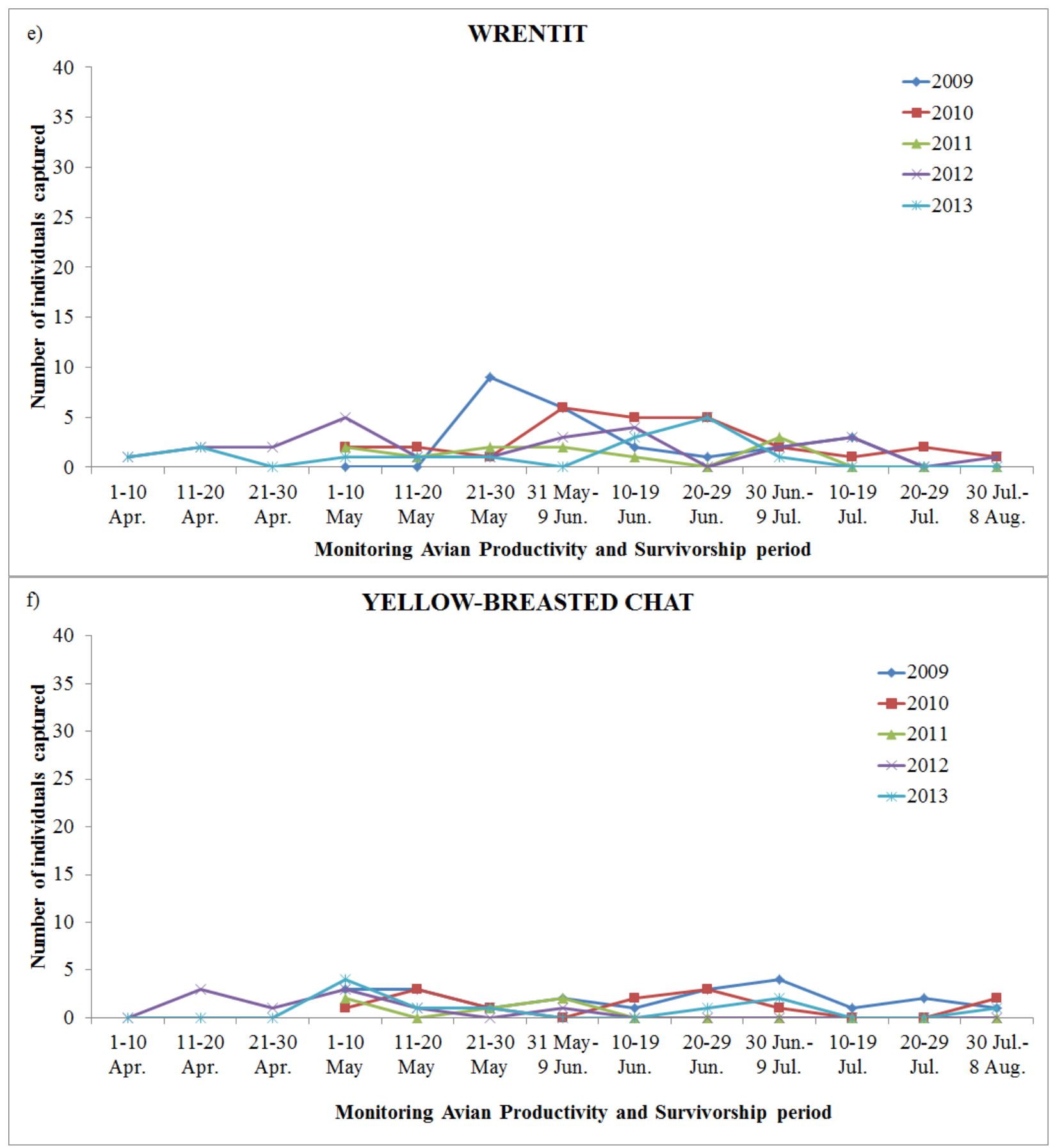

Figure B2.-Continued. 


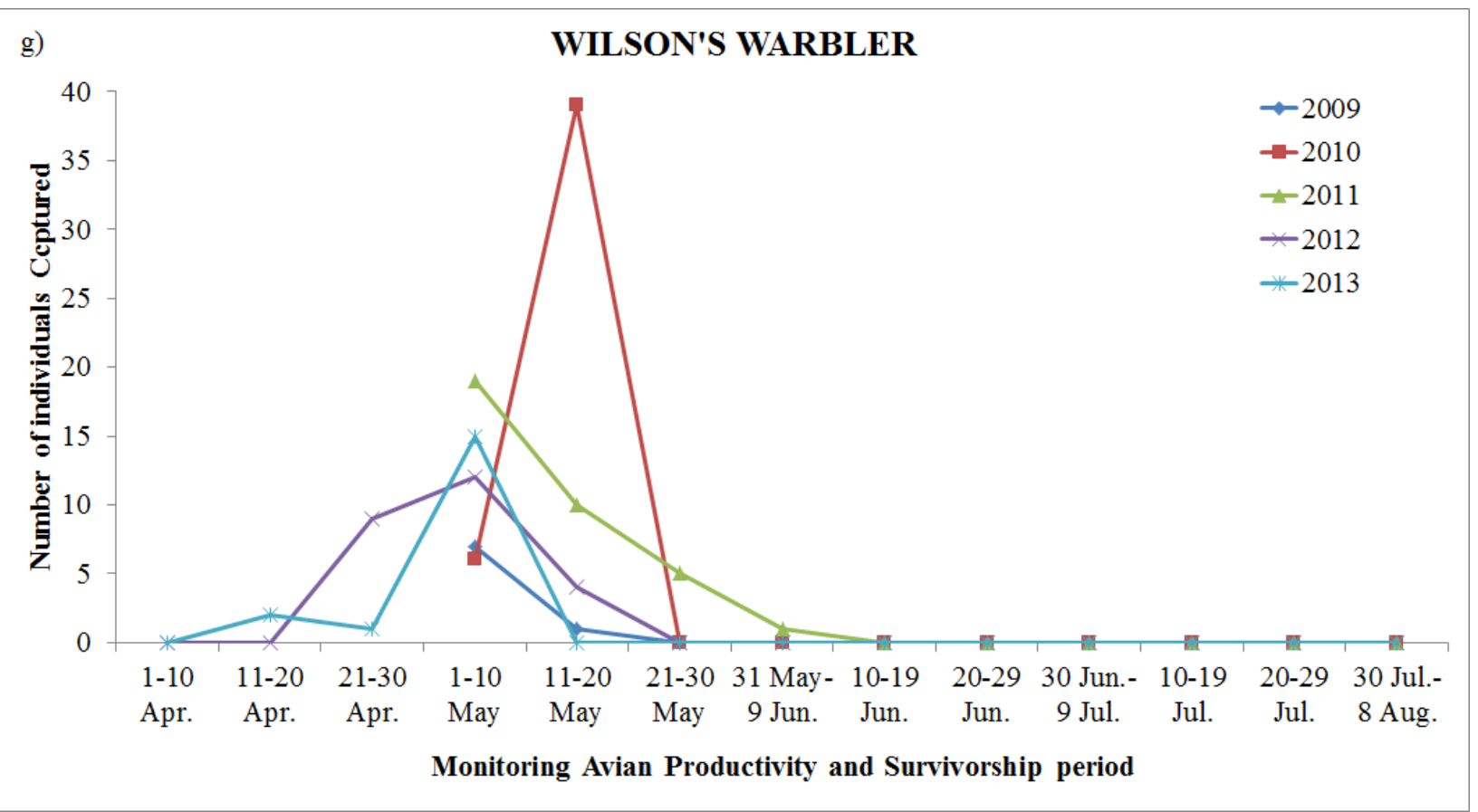

Figure B2.-Continued. 
Table B8. Sex and age of individual birds captured at Naval Outlying Landing Field, Imperial Beach, 2009.

[Species: See appendix A for common and scientific names. Age: HY, hatching-year, AHY, after-hatching-year; SY, second-year, ASY, after-second-year]

\begin{tabular}{|c|c|c|c|c|c|c|c|c|c|c|c|c|c|c|c|}
\hline \multirow[b]{2}{*}{ Species } & \multicolumn{3}{|c|}{ Female age } & \multirow{2}{*}{$\begin{array}{c}\text { Female } \\
\text { total }\end{array}$} & \multicolumn{4}{|c|}{ Male age } & \multirow{2}{*}{$\begin{array}{l}\text { Male } \\
\text { total }\end{array}$} & \multicolumn{4}{|c|}{ Unknown sex age } & \multirow{2}{*}{$\begin{array}{c}\text { Unknown } \\
\text { total }\end{array}$} & \multirow{2}{*}{$\begin{array}{c}\text { Species } \\
\text { total }\end{array}$} \\
\hline & HY & AHY & SY & & HY & AHY & SY & ASY & & HY & AHY & SY & ASY & & \\
\hline COGD & 0 & 0 & 0 & $\mathbf{0}$ & 0 & 2 & 0 & 0 & 2 & 0 & 0 & 0 & 0 & $\mathbf{0}$ & 2 \\
\hline PSFL & 0 & 1 & 1 & 2 & 0 & 0 & 0 & 1 & 1 & 2 & 6 & 3 & 0 & 11 & 14 \\
\hline BLPH & 0 & 0 & 0 & $\mathbf{0}$ & 0 & 0 & 0 & 0 & $\mathbf{0}$ & 0 & 0 & 1 & 0 & 1 & 1 \\
\hline ATFL & 0 & 0 & 0 & $\mathbf{0}$ & 0 & 0 & 0 & 0 & $\mathbf{0}$ & 0 & 1 & 3 & 0 & 4 & 4 \\
\hline LBVI & 0 & 4 & 0 & 4 & 0 & 2 & 0 & 0 & 2 & 1 & 0 & 0 & 0 & 1 & 7 \\
\hline WAVI & 0 & 0 & 0 & $\mathbf{0}$ & 0 & 0 & 0 & 0 & $\mathbf{0}$ & 0 & 1 & 0 & 0 & 1 & 1 \\
\hline REVI & 0 & 0 & 0 & $\mathbf{0}$ & 0 & 0 & 0 & 0 & $\mathbf{0}$ & 0 & 1 & 0 & 0 & 1 & 1 \\
\hline BUSH & 4 & 40 & 0 & 44 & 2 & 33 & 0 & 0 & 35 & 21 & 0 & 0 & 0 & 21 & 100 \\
\hline BEWR & 0 & 1 & 1 & 2 & 0 & 2 & 1 & 0 & 3 & 13 & 0 & 0 & 0 & 13 & 18 \\
\hline HOWR & 0 & 3 & 0 & 3 & 0 & 1 & 0 & 0 & 1 & 5 & 1 & 0 & 0 & 6 & 10 \\
\hline SWTH & 0 & 0 & 0 & $\mathbf{0}$ & 0 & 0 & 0 & 0 & $\mathbf{0}$ & 0 & 2 & 0 & 2 & 4 & 4 \\
\hline WREN & 0 & 0 & 0 & $\mathbf{0}$ & 0 & 0 & 0 & 0 & 0 & 4 & 19 & 0 & 0 & 23 & 23 \\
\hline OCWA & 0 & 8 & 1 & 9 & 0 & 12 & 1 & 0 & 13 & 30 & 0 & 0 & 0 & 30 & 52 \\
\hline NOPA & 0 & 1 & 0 & 1 & 0 & 0 & 0 & 0 & $\mathbf{0}$ & 0 & 0 & 0 & 0 & $\mathbf{0}$ & 1 \\
\hline YWAR & 0 & 1 & 1 & 2 & 0 & 2 & 0 & 0 & 2 & 0 & 0 & 0 & 0 & 0 & 4 \\
\hline MGWA & 0 & 0 & 1 & 1 & 0 & 0 & 0 & 0 & $\mathbf{0}$ & 0 & 0 & 0 & 0 & $\mathbf{0}$ & 1 \\
\hline COYE & 1 & 4 & 4 & 9 & 14 & 16 & 3 & 0 & 33 & 50 & 0 & 0 & 0 & 50 & 92 \\
\hline WIWA & 0 & 2 & 0 & 2 & 0 & 2 & 3 & 1 & 6 & 0 & 0 & 0 & 0 & 0 & 8 \\
\hline $\mathrm{YBCH}$ & 0 & 4 & 3 & 7 & 1 & 0 & 2 & 3 & 6 & 8 & 0 & 0 & 0 & 8 & 21 \\
\hline SPTO & 0 & 0 & 1 & 1 & 0 & 0 & 0 & 0 & $\mathbf{0}$ & 1 & 0 & 0 & 0 & 1 & 2 \\
\hline CALT & 0 & 0 & 0 & $\mathbf{0}$ & 0 & 1 & 1 & 0 & 2 & 0 & 0 & 0 & 0 & $\mathbf{0}$ & 2 \\
\hline SOSP & 2 & 4 & 6 & 12 & 1 & 7 & 2 & 0 & 10 & 47 & 0 & 0 & 0 & 47 & 69 \\
\hline HOOR & 0 & 0 & 0 & $\mathbf{0}$ & 0 & 0 & 0 & 0 & 0 & 1 & 0 & 0 & 0 & 1 & 1 \\
\hline HOFI & 0 & 0 & 0 & $\mathbf{0}$ & 0 & 0 & 0 & 0 & $\mathbf{0}$ & 1 & 0 & 0 & 0 & 1 & 1 \\
\hline LEGO & 1 & 0 & 0 & 1 & 0 & 0 & 0 & 0 & $\mathbf{0}$ & 0 & 0 & 0 & 0 & $\mathbf{0}$ & 1 \\
\hline AMGO & 0 & 1 & 0 & 1 & 0 & 0 & 1 & 0 & 1 & 1 & 0 & 0 & 0 & 1 & 3 \\
\hline Total & 8 & 74 & 19 & 101 & 20 & 80 & 14 & 5 & 117 & 185 & 31 & 7 & 2 & 225 & 443 \\
\hline
\end{tabular}


Table B9. Sex and age of individual birds captured at Naval Outlying Landing Field, Imperial Beach, 2010.

[Species: See appendix A for common and scientific names. Age: HY, hatching-year, AHY, after-hatching-year; SY, second-year, ASY, after-second-year; ATY, after third-year]

\begin{tabular}{|c|c|c|c|c|c|c|c|c|c|c|c|c|c|c|c|c|c|}
\hline \multirow[b]{2}{*}{ Species } & \multicolumn{5}{|c|}{ Female age } & \multirow{2}{*}{$\begin{array}{c}\text { Female } \\
\text { total }\end{array}$} & \multicolumn{4}{|c|}{ Male age } & \multirow{2}{*}{$\begin{array}{l}\text { Male } \\
\text { total }\end{array}$} & \multicolumn{4}{|c|}{ Unknown sex age } & \multirow{2}{*}{$\begin{array}{c}\text { Unknown } \\
\text { total }\end{array}$} & \multirow{2}{*}{$\begin{array}{c}\text { Species } \\
\text { total }\end{array}$} \\
\hline & HY & AHY & SY & ASY & ATY & & HY & AHY & SY & ASY & & HY & AHY & SY & ASY & & \\
\hline COGD & 0 & 0 & 0 & 0 & 0 & 0 & 0 & 1 & 0 & 0 & 1 & 1 & 0 & 0 & 0 & 1 & 2 \\
\hline NUWO & 0 & 1 & 0 & 0 & 0 & 1 & 1 & 0 & 0 & 0 & 1 & 1 & 0 & 0 & 0 & 1 & 3 \\
\hline DOWO & 1 & 1 & 0 & 0 & 1 & 3 & 1 & 0 & 0 & 0 & 1 & 0 & 0 & 0 & 0 & $\mathbf{0}$ & 4 \\
\hline PSFL & 0 & 1 & 1 & 0 & 0 & 2 & 0 & 0 & 0 & 0 & 0 & 1 & 3 & 9 & 2 & 15 & 17 \\
\hline ATFL & 0 & 0 & 0 & 0 & 0 & 0 & 0 & 0 & 0 & 0 & $\mathbf{0}$ & 0 & 1 & 0 & 0 & 1 & 1 \\
\hline LBVI & 0 & 0 & 2 & 2 & 0 & 4 & 0 & 0 & 1 & 1 & 2 & 7 & 0 & 0 & 0 & 7 & 13 \\
\hline HUVI & 0 & 0 & 0 & 0 & 0 & $\mathbf{0}$ & 0 & 0 & 0 & 0 & $\mathbf{0}$ & 1 & 0 & 0 & 0 & 1 & 1 \\
\hline WAVI & 0 & 0 & 0 & 0 & 0 & $\mathbf{0}$ & 0 & 0 & 0 & 0 & $\mathbf{0}$ & 0 & 0 & 2 & 0 & 2 & 2 \\
\hline NRWS & 1 & 0 & 0 & 0 & 0 & 1 & 0 & 0 & 0 & 0 & $\mathbf{0}$ & 0 & 0 & 0 & 0 & $\mathbf{0}$ & 1 \\
\hline BUSH & 34 & 15 & 0 & 1 & 0 & 50 & 4 & 11 & 1 & 3 & 19 & 29 & 0 & 0 & 0 & 29 & 98 \\
\hline BEWR & 0 & 1 & 1 & 1 & 0 & 3 & 0 & 1 & 1 & 0 & 2 & 12 & 0 & 0 & 0 & 12 & 17 \\
\hline HOWR & 0 & 2 & 1 & 1 & 0 & 4 & 0 & 2 & 0 & 0 & 2 & 16 & 0 & 1 & 0 & 17 & 23 \\
\hline SWTH & 0 & 0 & 1 & 0 & 0 & 1 & 0 & 1 & 0 & 1 & 2 & 0 & 4 & 0 & 9 & 13 & 16 \\
\hline WREN & 0 & 0 & 0 & 0 & 0 & 0 & 0 & 0 & 0 & 0 & $\mathbf{0}$ & 11 & 12 & 0 & 4 & 27 & 27 \\
\hline CATH & 0 & 0 & 0 & 0 & 0 & 0 & 0 & 0 & 0 & 0 & 0 & 3 & 0 & 0 & 0 & 3 & 3 \\
\hline OCWA & 0 & 3 & 5 & 4 & 0 & 12 & 1 & 1 & 6 & 5 & 13 & 44 & 0 & 0 & 0 & 44 & 69 \\
\hline YWAR & 0 & 0 & 1 & 0 & 0 & 1 & 0 & 0 & 8 & 4 & 12 & 0 & 0 & 1 & 0 & 1 & 14 \\
\hline COYE & 2 & 2 & 3 & 1 & 0 & 8 & 15 & 7 & 4 & 3 & 29 & 22 & 0 & 0 & 0 & 22 & 59 \\
\hline WIWA & 0 & 0 & 16 & 12 & 0 & 28 & 0 & 1 & 10 & 6 & 17 & 0 & 0 & 0 & 0 & $\mathbf{0}$ & 45 \\
\hline $\mathrm{YBCH}$ & 0 & 0 & 1 & 5 & 0 & 6 & 0 & 0 & 2 & 2 & 4 & 2 & 0 & 0 & 1 & 3 & 13 \\
\hline SPTO & 0 & 0 & 2 & 0 & 0 & 2 & 0 & 0 & 2 & 0 & 2 & 1 & 0 & 0 & 0 & 1 & 5 \\
\hline CALT & 0 & 1 & 0 & 1 & 0 & 2 & 0 & 1 & 0 & 1 & 2 & 2 & 0 & 0 & 0 & 2 & 6 \\
\hline SOSP & 1 & 0 & 5 & 3 & 0 & 9 & 3 & 2 & 6 & 2 & 13 & 39 & 3 & 0 & 0 & 42 & 64 \\
\hline WCSP & 0 & 0 & 0 & 0 & 0 & 0 & 0 & 0 & 0 & 0 & 0 & 0 & 0 & 1 & 0 & 1 & 1 \\
\hline LAZB & 0 & 0 & 1 & 0 & 0 & 1 & 0 & 0 & 0 & 0 & 0 & 0 & 0 & 0 & 0 & 0 & 1 \\
\hline HOFI & 0 & 0 & 0 & 0 & 0 & 0 & 0 & 0 & 0 & 0 & $\mathbf{0}$ & 3 & 0 & 0 & 0 & 3 & 3 \\
\hline LEGO & 0 & 0 & 0 & 0 & 0 & 0 & 0 & 1 & 0 & 0 & 1 & 0 & 0 & 0 & 0 & $\mathbf{0}$ & 1 \\
\hline AMGO & 0 & 0 & 2 & 0 & 0 & 2 & 1 & 0 & 1 & 0 & 2 & 1 & 0 & 0 & 0 & 1 & 5 \\
\hline Total & 39 & 27 & 42 & 31 & 1 & 140 & 26 & 29 & 42 & 28 & 125 & 196 & 23 & 14 & 16 & 249 & 514 \\
\hline
\end{tabular}


Table B10. Sex and age of individual birds captured at Naval Outlying Landing Field, Imperial Beach, 2011.

[Species: See appendix A for common and scientific names. Age: HY, hatching-year, AHY, after-hatching-year; SY, second-year, ASY, after-second-year; ATY, after third-year; I, indeterminable age]

\begin{tabular}{|c|c|c|c|c|c|c|c|c|c|c|c|c|c|c|c|c|c|c|}
\hline \multirow[b]{2}{*}{ Species } & \multicolumn{5}{|c|}{ Female age } & \multirow{2}{*}{$\begin{array}{c}\text { Female } \\
\text { total }\end{array}$} & \multicolumn{5}{|c|}{ Male age } & \multirow{2}{*}{$\begin{array}{l}\text { Male } \\
\text { total }\end{array}$} & \multicolumn{4}{|c|}{ Unknown sex age } & \multirow{2}{*}{$\begin{array}{c}\text { Unknown } \\
\text { total }\end{array}$} & \multirow{2}{*}{$\begin{array}{c}\text { Species } \\
\text { total }\end{array}$} \\
\hline & HY & AHY & SY & ASY & I & & HY & AHY & SY & ASY & ATY & & HY & AHY & SY & ASY & & \\
\hline COHA & 0 & 0 & 0 & 0 & 0 & o & 1 & 0 & 0 & 0 & 0 & 1 & 0 & 0 & 0 & 0 & 0 & 1 \\
\hline NUWO & 0 & 0 & 0 & 0 & 0 & 0 & 1 & 0 & 0 & 0 & 0 & 1 & 0 & 0 & 0 & 0 & $\mathbf{0}$ & 1 \\
\hline DOWO & 0 & 1 & 0 & 0 & 0 & 1 & 0 & 0 & 0 & 0 & 1 & 1 & 2 & 0 & 0 & 0 & 2 & 4 \\
\hline WIFL & 0 & 0 & 0 & 0 & 0 & $\mathbf{0}$ & 0 & 0 & 0 & 0 & 0 & 0 & 0 & 1 & 1 & 1 & 3 & 3 \\
\hline HAFL & 0 & 0 & 0 & 0 & 0 & 0 & 0 & 0 & 0 & 0 & 0 & $\mathbf{0}$ & 0 & 0 & 1 & 0 & 1 & 1 \\
\hline PSFL & 0 & 0 & 0 & 0 & 0 & 0 & 0 & 0 & 0 & 0 & 0 & 0 & 3 & 0 & 4 & 3 & 10 & 10 \\
\hline ATFL & 0 & 0 & 0 & 1 & 0 & 1 & 0 & 0 & 0 & 1 & 0 & 1 & 0 & 0 & 0 & 0 & 0 & 2 \\
\hline LBVI & 0 & 1 & 2 & 0 & 0 & 3 & 0 & 0 & 0 & 2 & 0 & 2 & 9 & 1 & 2 & 0 & 12 & 17 \\
\hline HUVI & 0 & 0 & 1 & 0 & 0 & 1 & 0 & 0 & 0 & 0 & 0 & 0 & 4 & 0 & 0 & 0 & 4 & 5 \\
\hline WAVI & 0 & 0 & 0 & 0 & 0 & $\mathbf{0}$ & 0 & 0 & 0 & 0 & 0 & $\mathbf{0}$ & 0 & 3 & 2 & 5 & 10 & 10 \\
\hline BUSH & 18 & 15 & 3 & 4 & 1 & 41 & 0 & 20 & 2 & 4 & 0 & 26 & 22 & 0 & 0 & 0 & 22 & 89 \\
\hline BEWR & 0 & 1 & 0 & 1 & 0 & 2 & 0 & 1 & 0 & 1 & 0 & 2 & 5 & 0 & 1 & 1 & 7 & 11 \\
\hline HOWR & 0 & 0 & 0 & 2 & 0 & 2 & 0 & 3 & 0 & 0 & 0 & 3 & 5 & 0 & 0 & 1 & 6 & 11 \\
\hline SWTH & 0 & 0 & 0 & 1 & 0 & 1 & 0 & 0 & 0 & 0 & 0 & 0 & 0 & 0 & 3 & 12 & 15 & 16 \\
\hline WREN & 0 & 0 & 0 & 0 & 0 & $\mathbf{0}$ & 0 & 0 & 0 & 0 & 0 & $\mathbf{0}$ & 3 & 2 & 1 & 5 & 11 & 11 \\
\hline OCWA & 1 & 0 & 2 & 8 & 0 & 11 & 0 & 1 & 2 & 5 & 0 & 8 & 7 & 0 & 0 & 0 & 7 & 26 \\
\hline NAWA & 0 & 0 & 0 & 1 & 0 & 1 & 0 & 0 & 2 & 0 & 0 & 2 & 0 & 0 & 0 & 0 & 0 & 3 \\
\hline YWAR & 0 & 0 & 0 & 1 & 0 & 1 & 0 & 0 & 3 & 3 & 0 & 6 & 0 & 0 & 0 & 0 & 0 & 7 \\
\hline TOWA & 0 & 1 & 0 & 0 & 0 & 1 & 0 & 0 & 0 & 0 & 0 & 0 & 0 & 0 & 0 & 0 & 0 & 1 \\
\hline MGWA & 0 & 0 & 0 & 0 & 0 & 0 & 0 & 0 & 1 & 0 & 0 & 1 & 0 & 0 & 0 & 0 & 0 & 1 \\
\hline COYE & 1 & 2 & 3 & 4 & 0 & 10 & 6 & 1 & 7 & 9 & 0 & 23 & 13 & 0 & 0 & 0 & 13 & 46 \\
\hline WIWA & 0 & 0 & 3 & 4 & 0 & 7 & 0 & 0 & 10 & 18 & 0 & 28 & 0 & 0 & 0 & 0 & $\mathbf{0}$ & 35 \\
\hline $\mathrm{YBCH}$ & 0 & 0 & 0 & 2 & 0 & 2 & 0 & 0 & 1 & 2 & 0 & 3 & 0 & 0 & 0 & 0 & 0 & 5 \\
\hline SPTO & 0 & 0 & 0 & 0 & 0 & 0 & 0 & 0 & 1 & 1 & 0 & 2 & 1 & 0 & 0 & 0 & 1 & 3 \\
\hline CALT & 0 & 0 & 0 & 0 & 0 & 0 & 0 & 0 & 1 & 0 & 0 & 1 & 0 & 1 & 0 & 0 & 1 & 2 \\
\hline SOSP & 0 & 1 & 9 & 8 & 0 & 18 & 0 & 1 & 3 & 0 & 0 & 4 & 49 & 0 & 1 & 1 & 51 & 73 \\
\hline WCSP & 0 & 0 & 0 & 0 & 0 & $\mathbf{0}$ & 0 & 0 & 1 & 0 & 0 & 1 & 0 & 0 & 0 & 0 & $\mathbf{0}$ & 1 \\
\hline GCSP & 0 & 0 & 0 & 0 & 0 & $\mathbf{0}$ & 0 & 0 & 0 & 0 & 0 & 0 & 0 & 0 & 1 & 0 & 1 & 1 \\
\hline NOCA & 0 & 1 & 0 & 0 & 0 & 1 & 0 & 0 & 0 & 0 & 0 & 0 & 0 & 0 & 0 & 0 & 0 & 1 \\
\hline HOFI & 0 & 0 & 0 & 0 & 0 & 0 & 0 & 3 & 2 & 0 & 0 & 5 & 1 & 0 & 0 & 0 & 1 & 6 \\
\hline AMGO & 1 & 0 & 1 & 2 & 0 & 4 & 1 & 0 & 0 & 2 & 0 & 3 & 3 & 0 & 0 & 0 & 3 & 10 \\
\hline Total & 21 & 23 & 24 & 39 & 1 & 108 & 9 & 30 & 36 & 48 & 1 & 124 & 127 & 8 & 17 & 29 & 181 & 413 \\
\hline
\end{tabular}


Table B11. Sex and age of individual birds captured at Naval Outlying Landing Field, Imperial Beach, 2012.

[Species: See appendix A for common and scientific names. Age: HY, hatching-year, AHY, after-hatching-year; SY, second-year, ASY, after-second-year]

\begin{tabular}{|c|c|c|c|c|c|c|c|c|c|c|c|c|c|c|c|c|}
\hline \multirow[b]{2}{*}{ Species } & \multicolumn{4}{|c|}{ Female age } & \multirow{2}{*}{$\begin{array}{c}\text { Female } \\
\text { total }\end{array}$} & \multicolumn{4}{|c|}{ Male age } & \multirow{2}{*}{$\begin{array}{l}\text { Male } \\
\text { total }\end{array}$} & \multicolumn{4}{|c|}{ Unknown sex age } & \multirow{2}{*}{$\begin{array}{c}\text { Unknown } \\
\text { total }\end{array}$} & \multirow{2}{*}{$\begin{array}{c}\text { Species } \\
\text { total }\end{array}$} \\
\hline & HY & AHY & SY & ASY & & HY & AHY & SY & ASY & & HY & AHY & SY & ASY & & \\
\hline COGD & 0 & 0 & 0 & 0 & $\mathbf{0}$ & 0 & 0 & 0 & 0 & $\mathbf{0}$ & 0 & 2 & 0 & 0 & 2 & 2 \\
\hline NUWO & 0 & 0 & 0 & 0 & $\mathbf{0}$ & 3 & 0 & 0 & 0 & 3 & 0 & 0 & 0 & 0 & $\mathbf{0}$ & 3 \\
\hline DOWO & 1 & 1 & 0 & 1 & 3 & 1 & 1 & 1 & 0 & 3 & 5 & 0 & 0 & 0 & 5 & 11 \\
\hline WIFL & 0 & 0 & 0 & 0 & $\mathbf{0}$ & 0 & 0 & 0 & 0 & $\mathbf{0}$ & 0 & 1 & 0 & 0 & 1 & 1 \\
\hline PSFL & 0 & 0 & 0 & 0 & $\mathbf{0}$ & 0 & 0 & 0 & 0 & $\mathbf{0}$ & 2 & 8 & 0 & 0 & 10 & 10 \\
\hline BLPH & 0 & 0 & 0 & 0 & $\mathbf{0}$ & 0 & 0 & 0 & 0 & $\mathbf{0}$ & 1 & 0 & 0 & 0 & 1 & 1 \\
\hline ATFL & 0 & 1 & 0 & 0 & 1 & 0 & 0 & 0 & 0 & $\mathbf{0}$ & 1 & 2 & 0 & 2 & 5 & 6 \\
\hline LBVI & 0 & 2 & 0 & 0 & 2 & 0 & 0 & 1 & 1 & 2 & 0 & 1 & 0 & 0 & 1 & 5 \\
\hline HUVI & 0 & 1 & 0 & 0 & 1 & 0 & 0 & 0 & 0 & $\mathbf{0}$ & 6 & 1 & 0 & 0 & 7 & 8 \\
\hline WAVI & 0 & 0 & 0 & 0 & $\mathbf{0}$ & 0 & 0 & 0 & 0 & $\mathbf{0}$ & 0 & 5 & 0 & 0 & 5 & 5 \\
\hline TRES & 0 & 0 & 0 & 0 & $\mathbf{0}$ & 0 & 1 & 0 & 0 & 1 & 0 & 0 & 0 & 0 & $\mathbf{0}$ & 1 \\
\hline CLSW & 0 & 1 & 0 & 0 & 1 & 0 & 0 & 0 & 0 & 0 & 0 & 6 & 0 & 0 & 6 & 7 \\
\hline BUSH & 34 & 22 & 2 & 13 & 71 & 3 & 11 & 0 & 6 & 20 & 37 & 0 & 0 & 1 & 38 & 129 \\
\hline BEWR & 0 & 3 & 0 & 1 & 4 & 1 & 0 & 0 & 1 & 2 & 7 & 6 & 0 & 0 & 13 & 19 \\
\hline HOWR & 0 & 4 & 0 & 3 & 7 & 1 & 7 & 0 & 1 & 9 & 4 & 7 & 0 & 0 & 11 & 27 \\
\hline SWTH & 0 & 0 & 0 & 0 & $\mathbf{0}$ & 0 & 0 & 0 & 0 & $\mathbf{0}$ & 0 & 8 & 1 & 2 & 11 & 11 \\
\hline HETH & 0 & 0 & 0 & 0 & $\mathbf{0}$ & 0 & 0 & 0 & 0 & $\mathbf{0}$ & 0 & 2 & 3 & 0 & 5 & 5 \\
\hline WREN & 0 & 0 & 0 & 0 & $\mathbf{0}$ & 0 & 0 & 0 & 0 & $\mathbf{0}$ & 8 & 11 & 0 & 6 & 25 & 25 \\
\hline CATH & 0 & 0 & 0 & 0 & $\mathbf{0}$ & 0 & 1 & 0 & 0 & 1 & 1 & 0 & 0 & 0 & 1 & 2 \\
\hline OCWA & 0 & 9 & 4 & 14 & 27 & 0 & 4 & 3 & 21 & 28 & 16 & 2 & 0 & 0 & 18 & 73 \\
\hline YWAR & 0 & 0 & 8 & 0 & 8 & 0 & 3 & 4 & 3 & 10 & 1 & 0 & 1 & 0 & 2 & 20 \\
\hline AUWA & 0 & 0 & 0 & 2 & 2 & 0 & 1 & 2 & 5 & 8 & 0 & 0 & 0 & 0 & 0 & 10 \\
\hline TOWA & 0 & 0 & 0 & 0 & $\mathbf{0}$ & 0 & 0 & 1 & 0 & 1 & 0 & 0 & 0 & 0 & $\mathbf{0}$ & 1 \\
\hline HEWA & 0 & 0 & 0 & 0 & 0 & 0 & 1 & 0 & 0 & 1 & 0 & 0 & 0 & 0 & $\mathbf{0}$ & 1 \\
\hline COYE & 2 & 7 & 6 & 11 & 26 & 8 & 11 & 7 & 17 & 43 & 27 & 0 & 0 & 0 & 27 & 96 \\
\hline WIWA & 0 & 0 & 6 & 2 & 8 & 0 & 1 & 4 & 9 & 14 & 0 & 3 & 0 & 0 & 3 & 25 \\
\hline $\mathrm{YBCH}$ & 0 & 0 & 1 & 0 & 1 & 0 & 3 & 2 & 3 & 8 & 0 & 0 & 0 & 0 & $\mathbf{0}$ & 9 \\
\hline SPTO & 0 & 0 & 1 & 1 & 2 & 0 & 0 & 0 & 1 & 1 & 4 & 0 & 0 & 0 & 4 & 7 \\
\hline CALT & 0 & 1 & 0 & 0 & 1 & 0 & 1 & 0 & 0 & 1 & 4 & 0 & 0 & 0 & 4 & 6 \\
\hline SOSP & 2 & 12 & 0 & 4 & 18 & 1 & 12 & 0 & 6 & 19 & 51 & 8 & 0 & 0 & 59 & 96 \\
\hline LISP & 0 & 0 & 0 & 0 & $\mathbf{0}$ & 0 & 0 & 0 & 0 & $\mathbf{0}$ & 0 & 4 & 0 & 0 & 4 & 4 \\
\hline WCSP & 0 & 0 & 0 & 0 & 0 & 0 & 0 & 0 & 0 & 0 & 0 & 18 & 2 & 0 & 20 & 20 \\
\hline GCSP & 0 & 0 & 0 & 0 & $\mathbf{0}$ & 0 & 0 & 0 & 0 & $\mathbf{0}$ & 0 & 1 & 2 & 0 & 3 & 3 \\
\hline BHGR & 0 & 1 & 0 & 0 & 1 & 0 & 0 & 0 & 1 & 1 & 0 & 0 & 0 & 0 & $\mathbf{0}$ & 2 \\
\hline HOFI & 0 & 0 & 0 & 0 & 0 & 1 & 12 & 0 & 0 & 13 & 11 & 0 & 0 & 0 & 11 & 24 \\
\hline LEGO & 0 & 0 & 0 & 0 & $\mathbf{0}$ & 0 & 0 & 1 & 0 & 1 & 1 & 0 & 0 & 0 & 1 & 2 \\
\hline LAGO & 0 & 1 & 0 & 0 & 1 & 0 & 1 & 0 & 1 & 2 & 0 & 0 & 0 & 0 & $\mathbf{0}$ & 3 \\
\hline AMGO & 0 & 1 & 2 & 1 & 4 & 1 & 0 & 0 & 0 & 1 & 0 & 0 & 0 & 0 & $\mathbf{0}$ & 5 \\
\hline Total & 39 & 67 & 30 & 53 & 189 & 20 & 71 & 26 & 76 & 193 & 187 & 96 & 9 & 11 & 303 & 685 \\
\hline
\end{tabular}


Table B12. Sex and age of individual birds captured at Naval Outlying Landing Field, Imperial Beach, 2013.

[Species: See appendix A for common and scientific names. Age: HY, hatching-year, AHY, after-hatching-year; SY, second-year, ASY, after-second-year; ATY, after third-year]

\begin{tabular}{|c|c|c|c|c|c|c|c|c|c|c|c|c|c|c|c|c|c|c|}
\hline \multirow[b]{2}{*}{ Species } & \multicolumn{5}{|c|}{ Female age } & \multirow{2}{*}{$\begin{array}{c}\text { Female } \\
\text { total }\end{array}$} & \multicolumn{5}{|c|}{ Male age } & \multirow{2}{*}{$\begin{array}{l}\text { Male } \\
\text { total }\end{array}$} & \multicolumn{4}{|c|}{ Unknown sex age } & \multirow{2}{*}{$\begin{array}{c}\text { Unknown } \\
\text { total }\end{array}$} & \multirow{2}{*}{$\begin{array}{c}\text { Species } \\
\text { total }\end{array}$} \\
\hline & HY & AHY & SY & ASY & ATY & & HY & AHY & SY & ASY & ATY & & HY & AHY & SY & ASY & & \\
\hline COGD & 0 & 0 & 0 & 0 & 0 & $\mathbf{0}$ & 0 & 0 & 0 & 0 & 0 & $\mathbf{0}$ & 2 & 1 & 0 & 0 & 3 & 3 \\
\hline NUWO & 0 & 0 & 0 & 0 & 0 & $\mathbf{0}$ & 1 & 0 & 0 & 0 & 1 & 2 & 0 & 0 & 0 & 0 & $\mathbf{0}$ & 2 \\
\hline DOWO & 0 & 0 & 0 & 0 & 1 & 1 & 3 & 1 & 0 & 0 & 0 & 4 & 0 & 0 & 0 & 0 & $\mathbf{0}$ & 5 \\
\hline WIFL & 0 & 0 & 0 & 0 & 0 & $\mathbf{0}$ & 0 & 0 & 0 & 0 & 0 & $\mathbf{0}$ & 0 & 2 & 1 & 0 & 3 & 3 \\
\hline PSFL & 0 & 0 & 0 & 0 & 0 & $\mathbf{0}$ & 0 & 0 & 0 & 0 & 0 & $\mathbf{0}$ & 0 & 8 & 1 & 0 & 9 & 9 \\
\hline ATFL & 0 & 0 & 1 & 0 & 0 & 1 & 0 & 0 & 0 & 1 & 0 & 1 & 0 & 0 & 1 & 2 & 3 & 5 \\
\hline LBVI & 0 & 2 & 0 & 0 & 0 & 2 & 0 & 0 & 0 & 2 & 0 & 2 & 4 & 4 & 0 & 0 & 8 & 12 \\
\hline HUVI & 0 & 1 & 0 & 0 & 0 & 1 & 0 & 0 & 0 & 0 & 0 & 0 & 2 & 0 & 0 & 0 & 2 & 3 \\
\hline WAVI & 0 & 0 & 0 & 0 & 0 & $\mathbf{0}$ & 0 & 0 & 0 & 0 & 0 & $\mathbf{0}$ & 0 & 5 & 1 & 0 & 6 & 6 \\
\hline REVI & 0 & 0 & 0 & 0 & 0 & $\mathbf{0}$ & 0 & 0 & 0 & 0 & 0 & $\mathbf{0}$ & 0 & 1 & 0 & 0 & 1 & 1 \\
\hline NRWS & 0 & 1 & 0 & 0 & 0 & 1 & 0 & 0 & 0 & 0 & 0 & 0 & 0 & 0 & 0 & 0 & 0 & 1 \\
\hline BUSH & 20 & 10 & 0 & 5 & 0 & 35 & 0 & 15 & 3 & 6 & 0 & 24 & 27 & 0 & 0 & 0 & 27 & 86 \\
\hline BEWR & 0 & 0 & 0 & 1 & 0 & 1 & 0 & 0 & 1 & 0 & 0 & 1 & 8 & 3 & 1 & 1 & 13 & 15 \\
\hline HOWR & 0 & 4 & 0 & 0 & 0 & 4 & 0 & 2 & 1 & 2 & 0 & 5 & 11 & 4 & 0 & 2 & 17 & 26 \\
\hline SWTH & 0 & 0 & 0 & 0 & 0 & $\mathbf{0}$ & 0 & 0 & 0 & 0 & 0 & 0 & 0 & 4 & 0 & 3 & 7 & 7 \\
\hline HETH & 0 & 0 & 0 & 0 & 0 & 0 & 0 & 0 & 0 & 0 & 0 & 0 & 0 & 0 & 2 & 0 & 2 & 2 \\
\hline WREN & 0 & 0 & 0 & 0 & 0 & $\mathbf{0}$ & 0 & 0 & 0 & 0 & 0 & $\mathbf{0}$ & 7 & 1 & 1 & 6 & 15 & 15 \\
\hline CATH & 0 & 0 & 0 & 0 & 0 & 0 & 0 & 0 & 0 & 0 & 0 & 0 & 0 & 3 & 0 & 0 & 3 & 3 \\
\hline OCWA & 0 & 4 & 9 & 18 & 0 & 31 & 3 & 7 & 9 & 25 & 0 & 44 & 20 & 3 & 0 & 2 & 25 & 100 \\
\hline YWAR & 0 & 0 & 0 & 2 & 0 & 2 & 0 & 0 & 3 & 2 & 0 & 5 & 0 & 0 & 0 & 0 & $\mathbf{0}$ & 7 \\
\hline AUWA & 0 & 0 & 1 & 0 & 0 & 1 & 0 & 0 & 0 & 1 & 0 & 1 & 0 & 0 & 0 & 0 & $\mathbf{0}$ & 2 \\
\hline HEWA & 0 & 0 & 0 & 0 & 0 & 0 & 0 & 1 & 0 & 1 & 0 & 2 & 0 & 0 & 0 & 0 & 0 & 2 \\
\hline MGW & 0 & 1 & 0 & 0 & 0 & 1 & 0 & 0 & 1 & 1 & 0 & 2 & 0 & 0 & 0 & 0 & 0 & 3 \\
\hline COYE & 0 & 2 & 4 & 8 & 0 & 14 & 16 & 3 & 8 & 17 & 0 & 44 & 21 & 0 & 0 & 0 & 21 & 79 \\
\hline WIWA & 0 & 0 & 0 & 4 & 0 & 4 & 0 & 0 & 2 & 9 & 0 & 11 & 0 & 1 & 0 & 2 & 3 & 18 \\
\hline YBCH & 0 & 0 & 0 & 2 & 0 & 2 & 0 & 0 & 3 & 3 & 0 & 6 & 2 & 0 & 0 & 0 & 2 & 10 \\
\hline SPTO & 0 & 0 & 2 & 0 & 0 & 2 & 0 & 1 & 2 & 0 & 0 & 3 & 2 & 0 & 0 & 0 & 2 & 7 \\
\hline CALT & 0 & 0 & 0 & 0 & 0 & 0 & 0 & 1 & 0 & 0 & 0 & 1 & 3 & 2 & 0 & 0 & 5 & 6 \\
\hline FOSP & 0 & 0 & 0 & 0 & 0 & $\mathbf{0}$ & 0 & 0 & 0 & 0 & 0 & 0 & 0 & 1 & 0 & 0 & 1 & 1 \\
\hline SOSP & 0 & 6 & 2 & 6 & 0 & 14 & 0 & 7 & 1 & 10 & 0 & 18 & 83 & 7 & 1 & 0 & 91 & 123 \\
\hline LISP & 0 & 0 & 0 & 0 & 0 & $\mathbf{0}$ & 0 & 0 & 0 & 0 & 0 & $\mathbf{0}$ & 0 & 5 & 0 & 3 & 8 & 8 \\
\hline WCSP & 0 & 0 & 0 & 0 & 0 & 0 & 0 & 0 & 0 & 0 & 0 & 0 & 0 & 12 & 11 & 3 & 26 & 26 \\
\hline GCSP & 0 & 0 & 0 & 0 & 0 & 0 & 0 & 0 & 0 & 0 & 0 & 0 & 0 & 1 & 0 & 1 & 2 & 2 \\
\hline BHGR & 0 & 0 & 1 & 0 & 0 & 1 & 0 & 0 & 0 & 0 & 0 & 0 & 0 & 0 & 0 & 0 & 0 & 1 \\
\hline HOOR & 0 & 1 & 0 & 0 & 0 & 1 & 0 & 0 & 0 & 0 & 0 & 0 & 0 & 0 & 0 & 0 & $\mathbf{0}$ & 1 \\
\hline HOFI & 0 & 4 & 0 & 0 & 0 & 4 & 0 & 8 & 0 & 1 & 0 & 9 & 9 & 0 & 0 & 0 & 9 & 22 \\
\hline LEGO & 0 & 0 & 0 & 0 & 0 & 0 & 0 & 0 & 0 & 0 & 0 & 0 & 1 & 0 & 0 & 0 & 1 & 1 \\
\hline AMGO & 0 & 1 & 0 & 1 & 0 & 2 & 1 & 1 & 0 & 0 & 0 & 2 & 0 & 0 & 0 & 0 & $\mathbf{0}$ & 4 \\
\hline Total & 20 & 37 & 20 & 47 & 1 & 125 & 24 & 47 & 34 & 81 & 1 & 187 & 202 & 68 & 20 & 25 & 315 & 627 \\
\hline
\end{tabular}




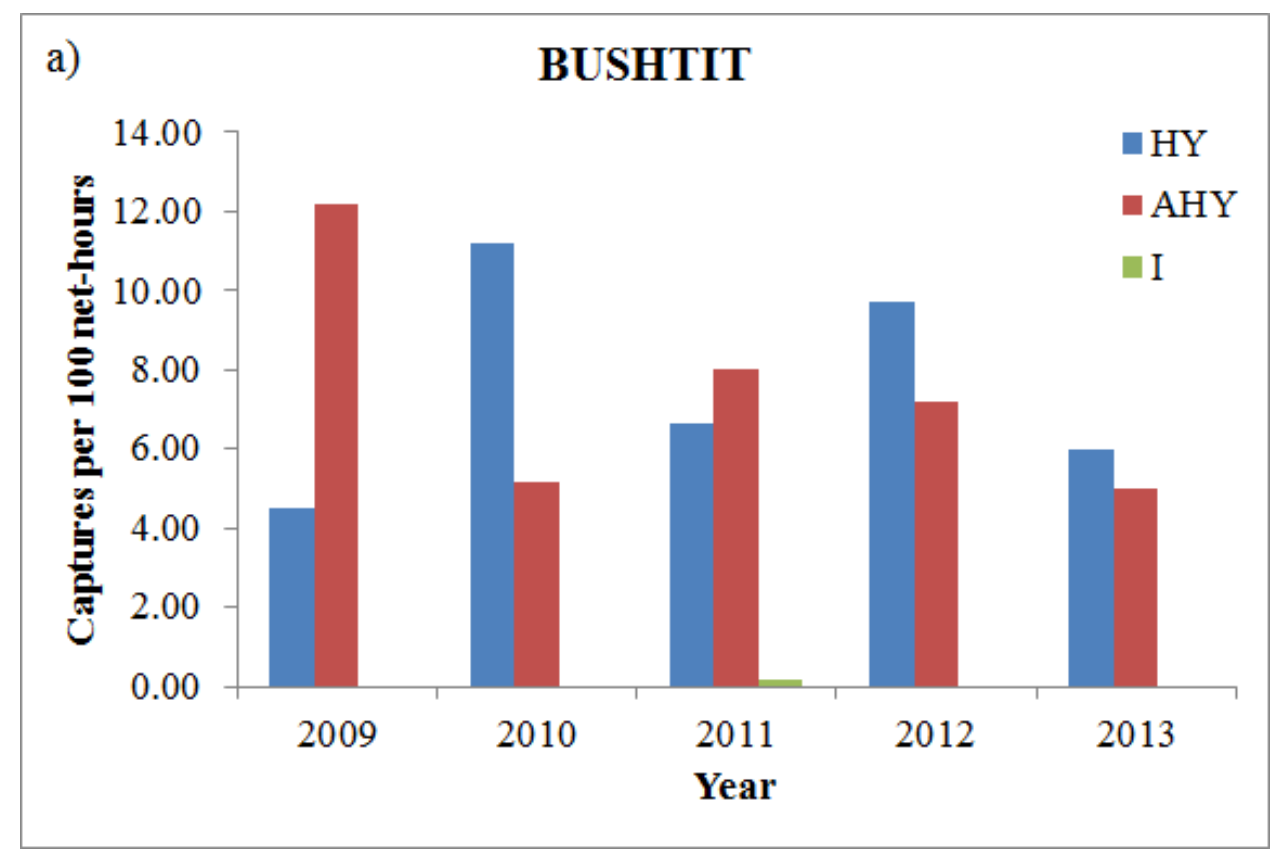

b) WRENTIT

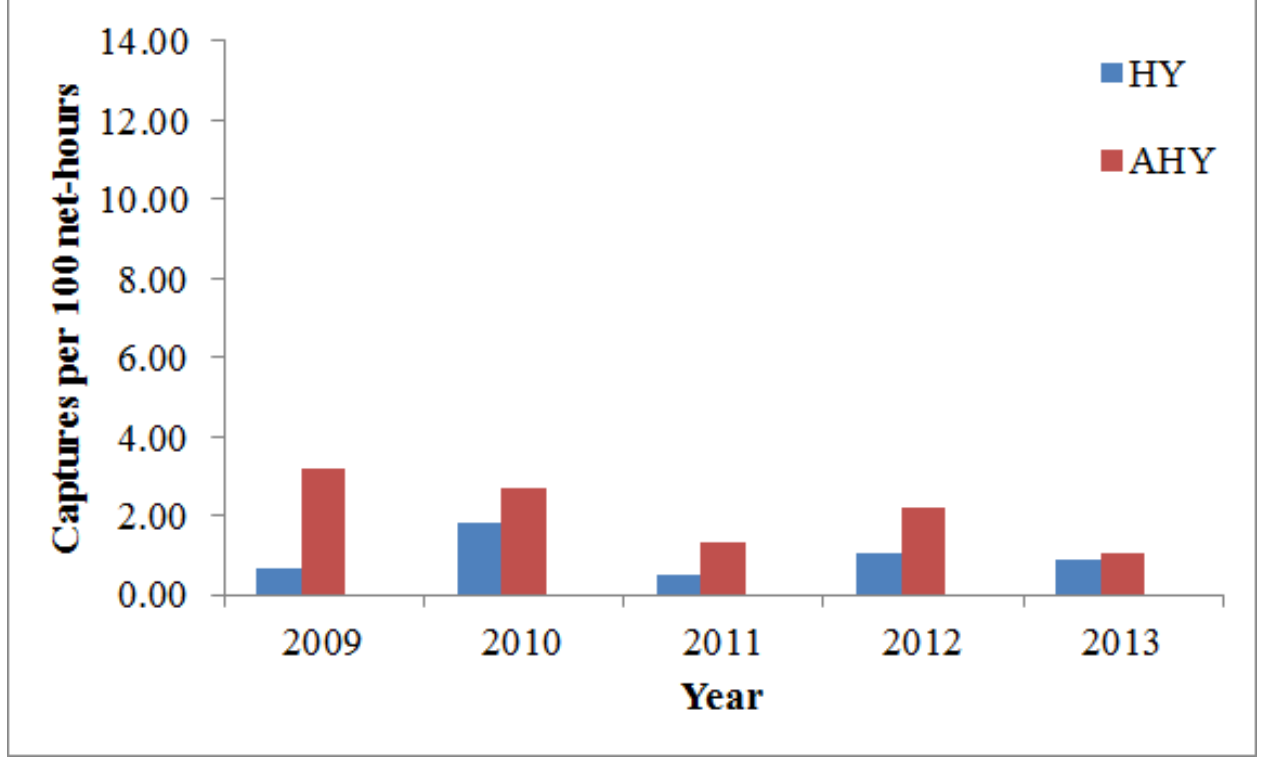

Figure B3. Annual variation in individuals captured per 100 net-hours for the most frequently captured yearround resident species (a-e) and migratory species (f-g) that breed at Naval Outlying Landing Field, Imperial Beach, 2009-13. Capture rates are divided into adults (AHY, after hatching-year), juveniles (HY, hatching-year), and birds of indeterminable age (I). 

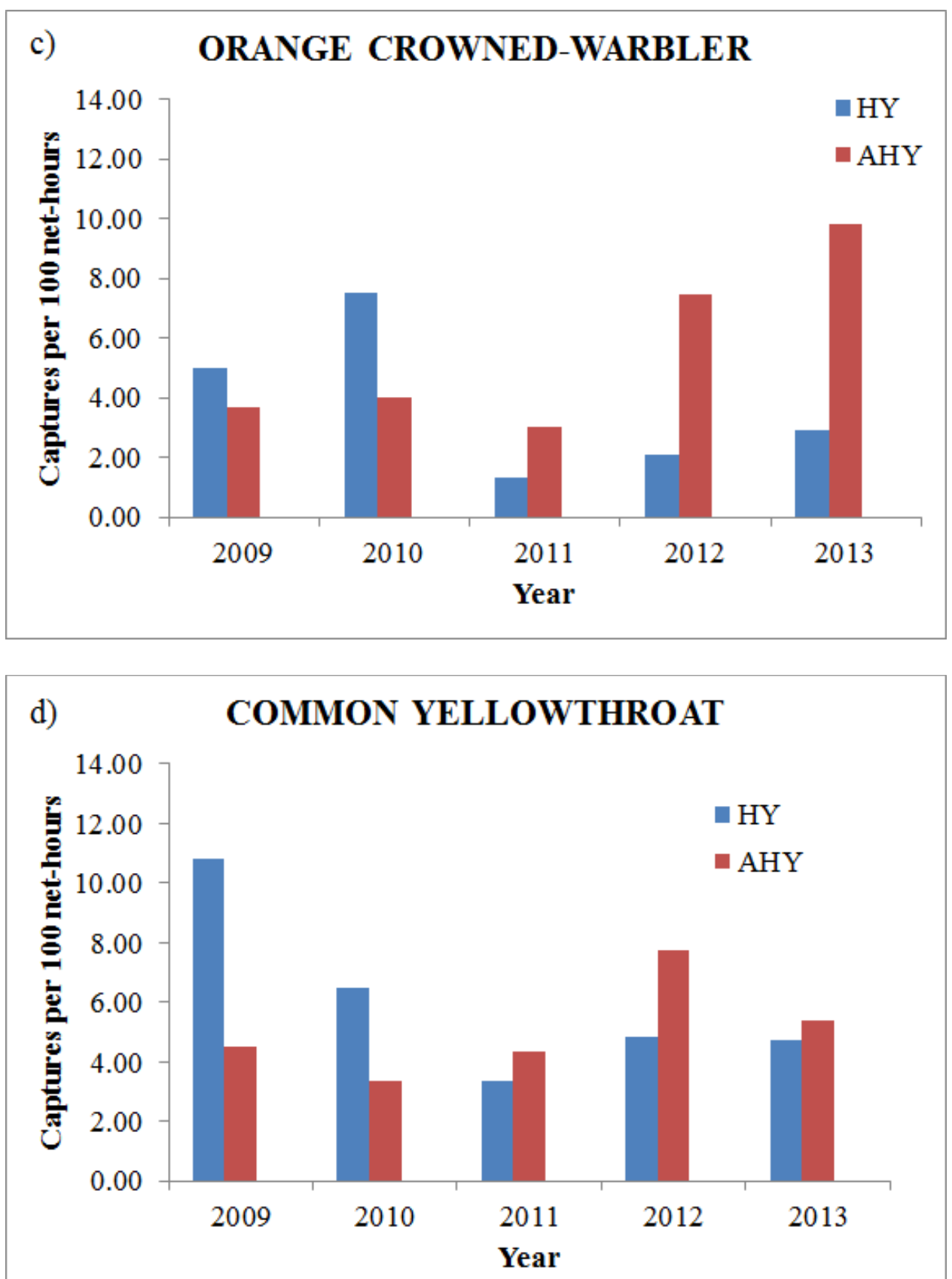

Figure B3.-Continued. 

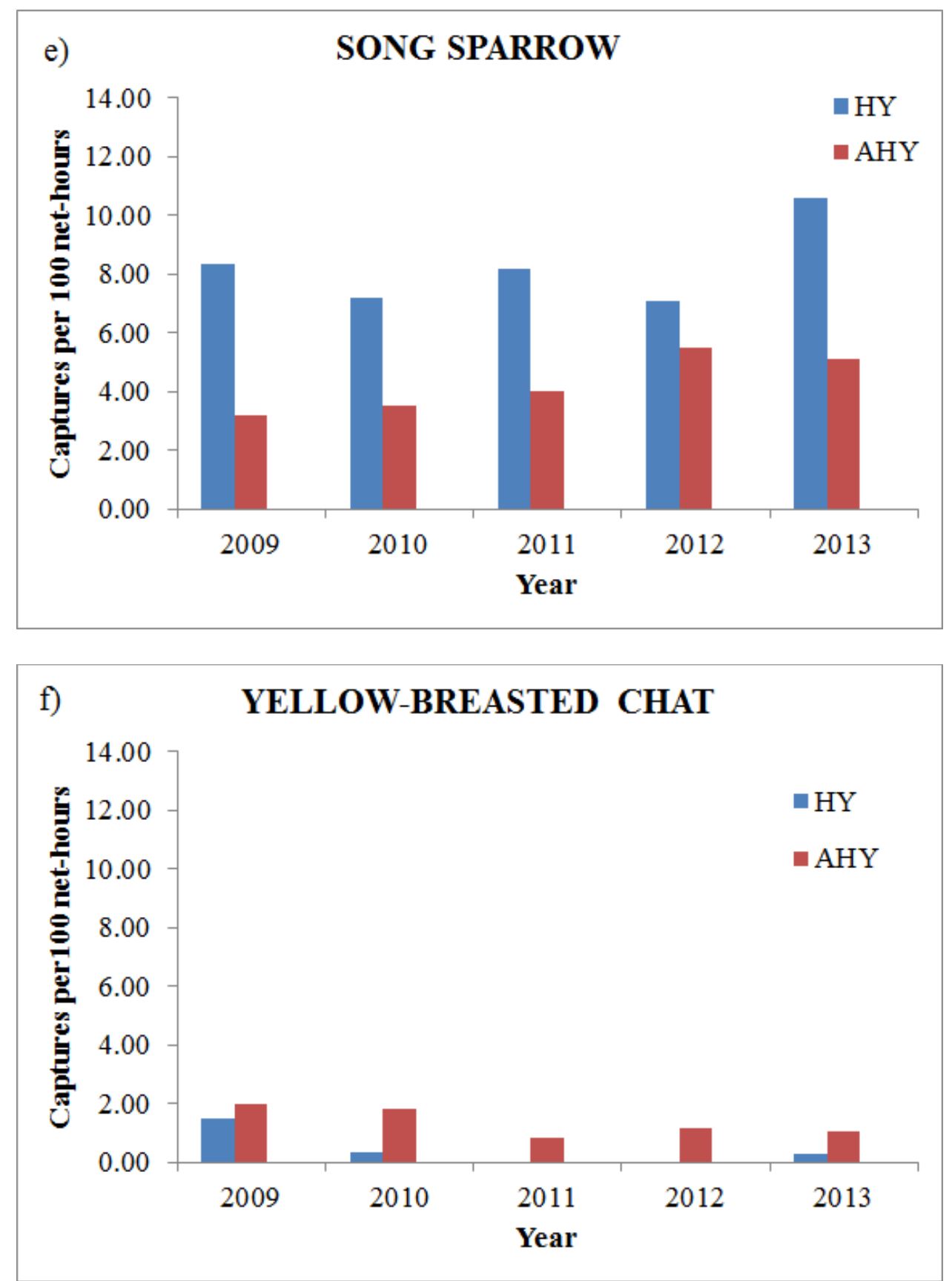

Figure B3.-Continued. 


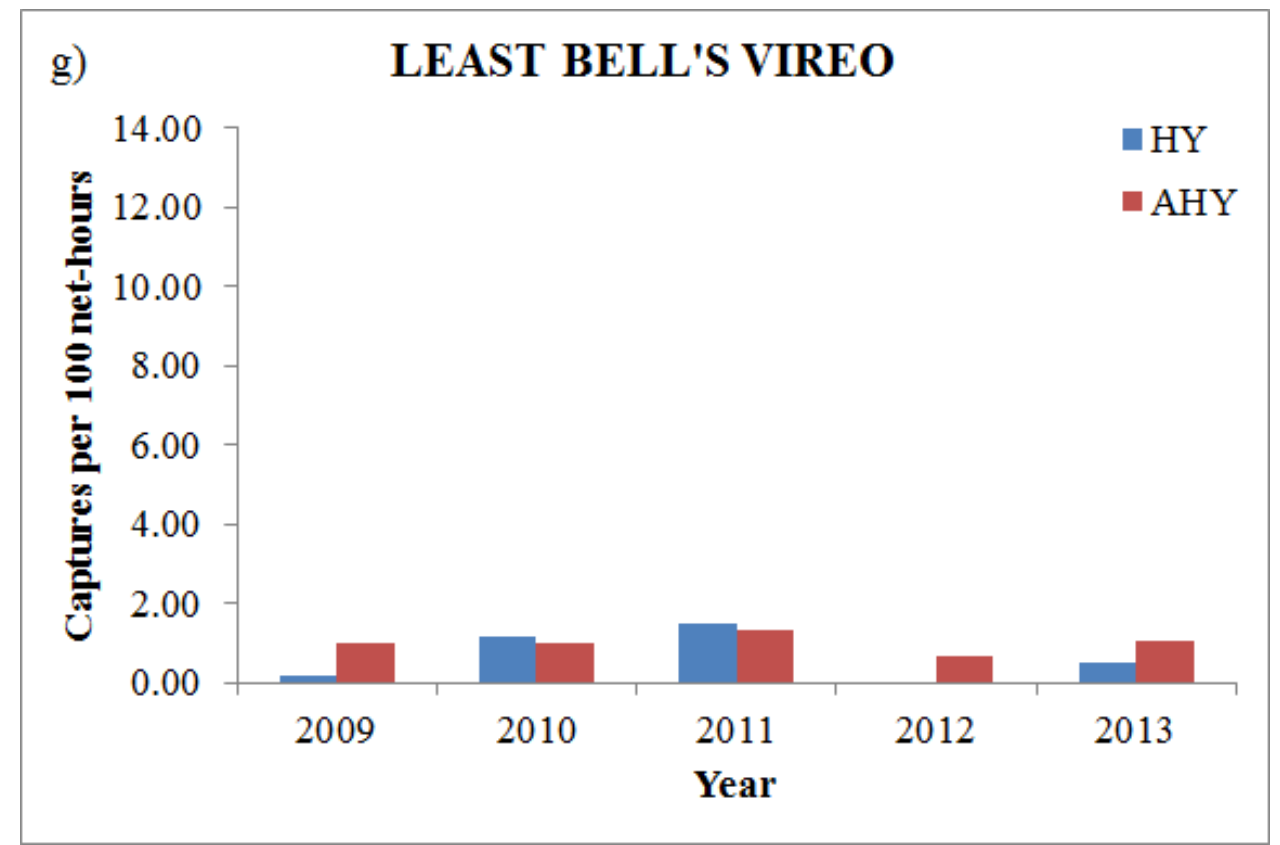

Figure B3.-Continued. 

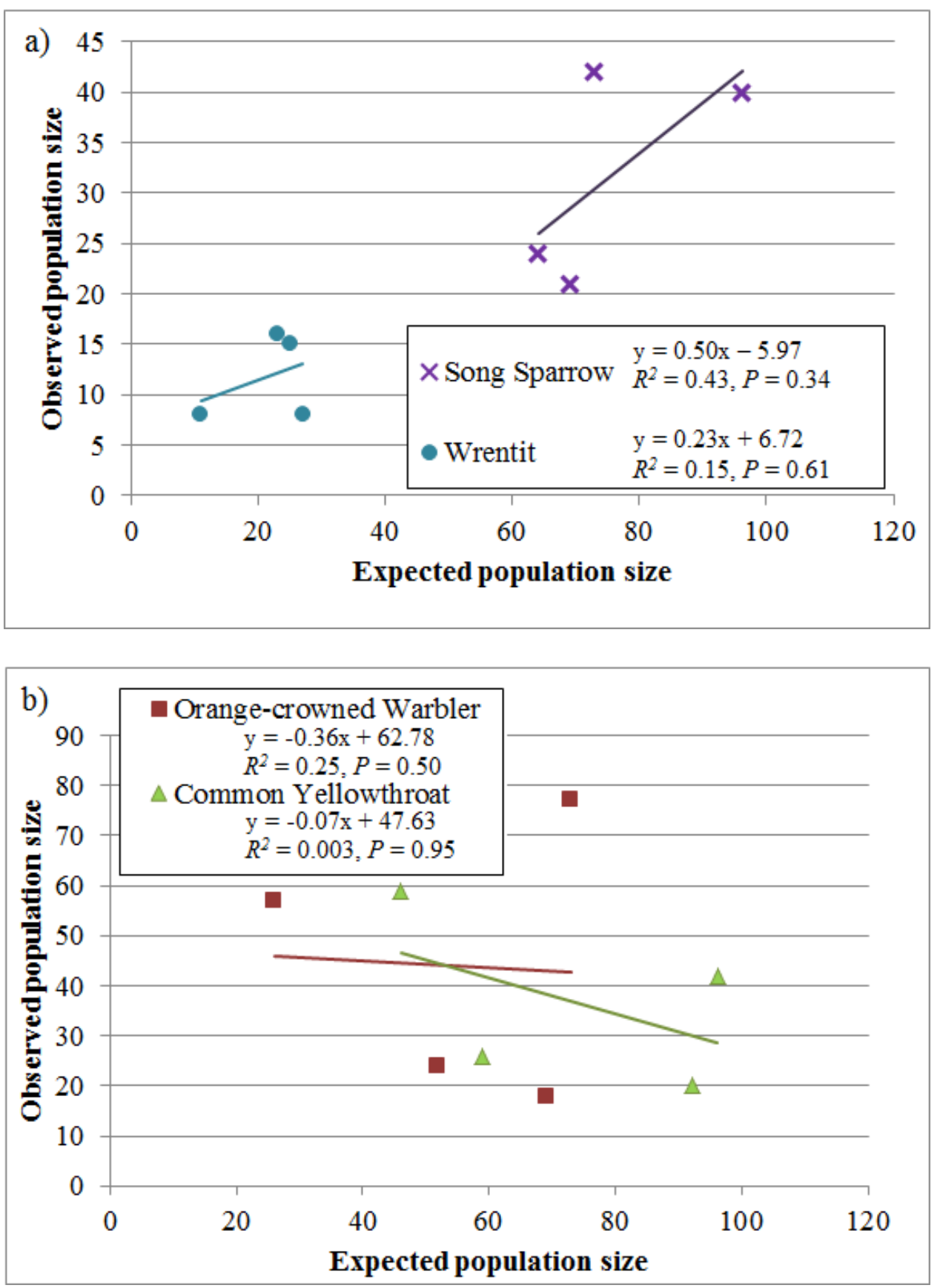

Figure B4. Comparison of expected population size with observed population size for year-round resident bird species (a, b) and migratory bird species (c) that breed at Naval Outlying Landing Field, Imperial Beach, 2009_ 13. Population size: total number of individuals captured plus first time recaptures of birds banded in previous years. Estimates were calculated using annual productivity estimates (expected population size in year $_{x}=$ observed population size in year $r_{x-1}+$ [observed population size in year $x_{x-1} \times$ productivity in year $_{x-1}$ ). 


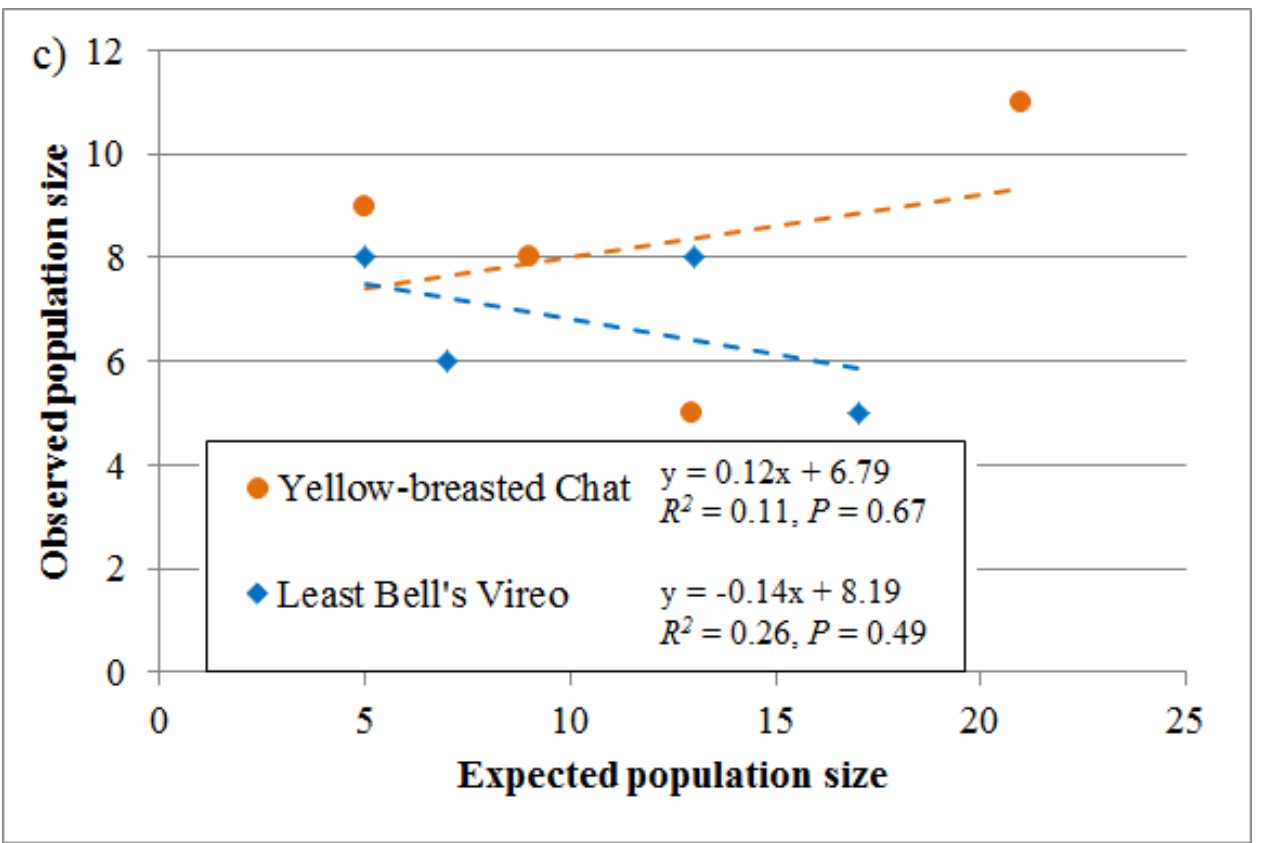

Figure B4.-Continued. 

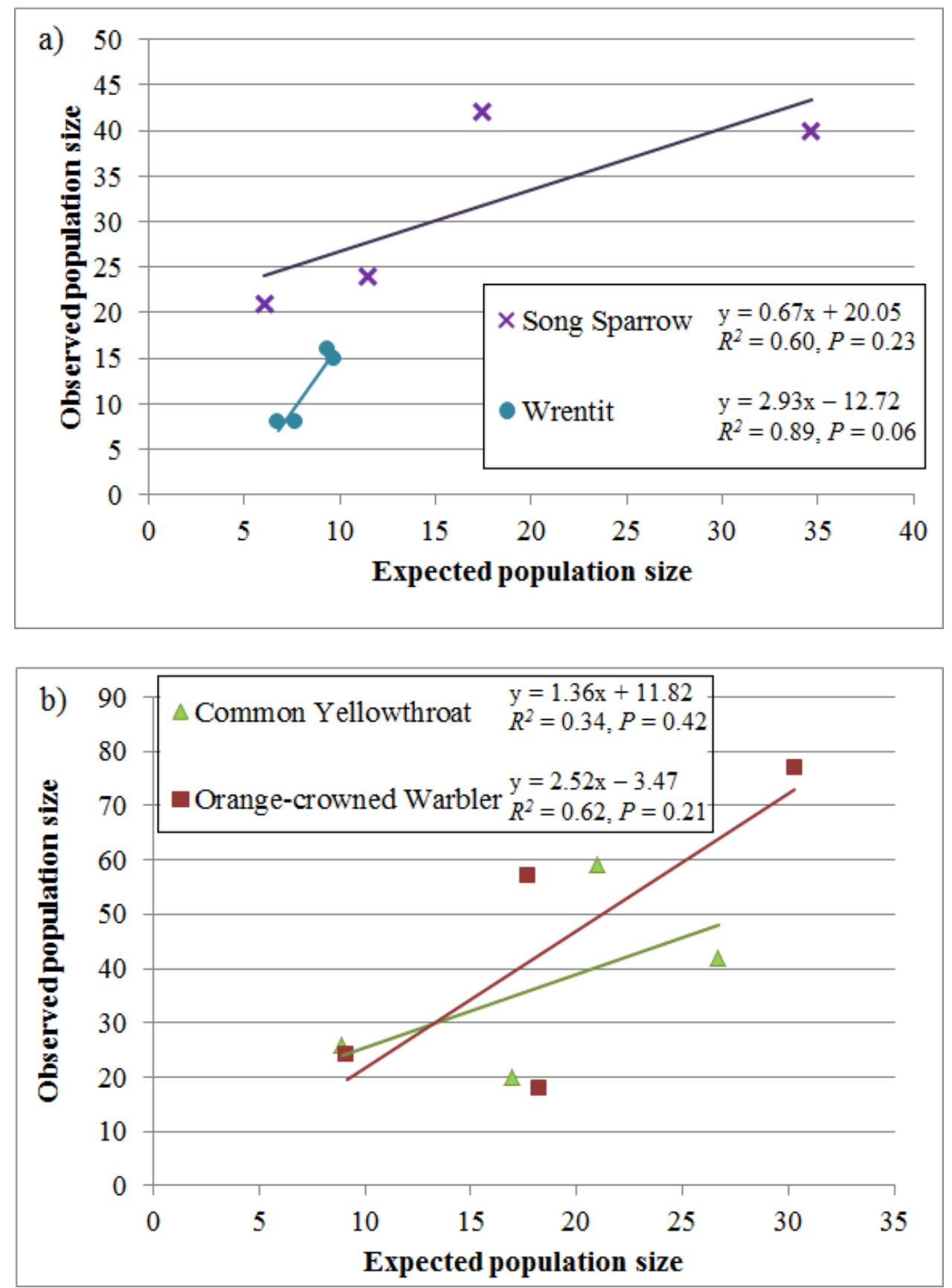

Figure B5. Comparison of expected population size with observed population size for year-round resident bird species (a, b) and migratory bird species (c) that breed at Naval Outlying Landing Field, Imperial Beach, 200913. Population size: total number of individuals captured plus first time recaptures of birds banded in previous years. Estimates were calculated using annual survivorship estimates (expected population size in year $x_{x}=$ observed population size in year $x_{x-1} \times$ survivorship to year $x$ ). 


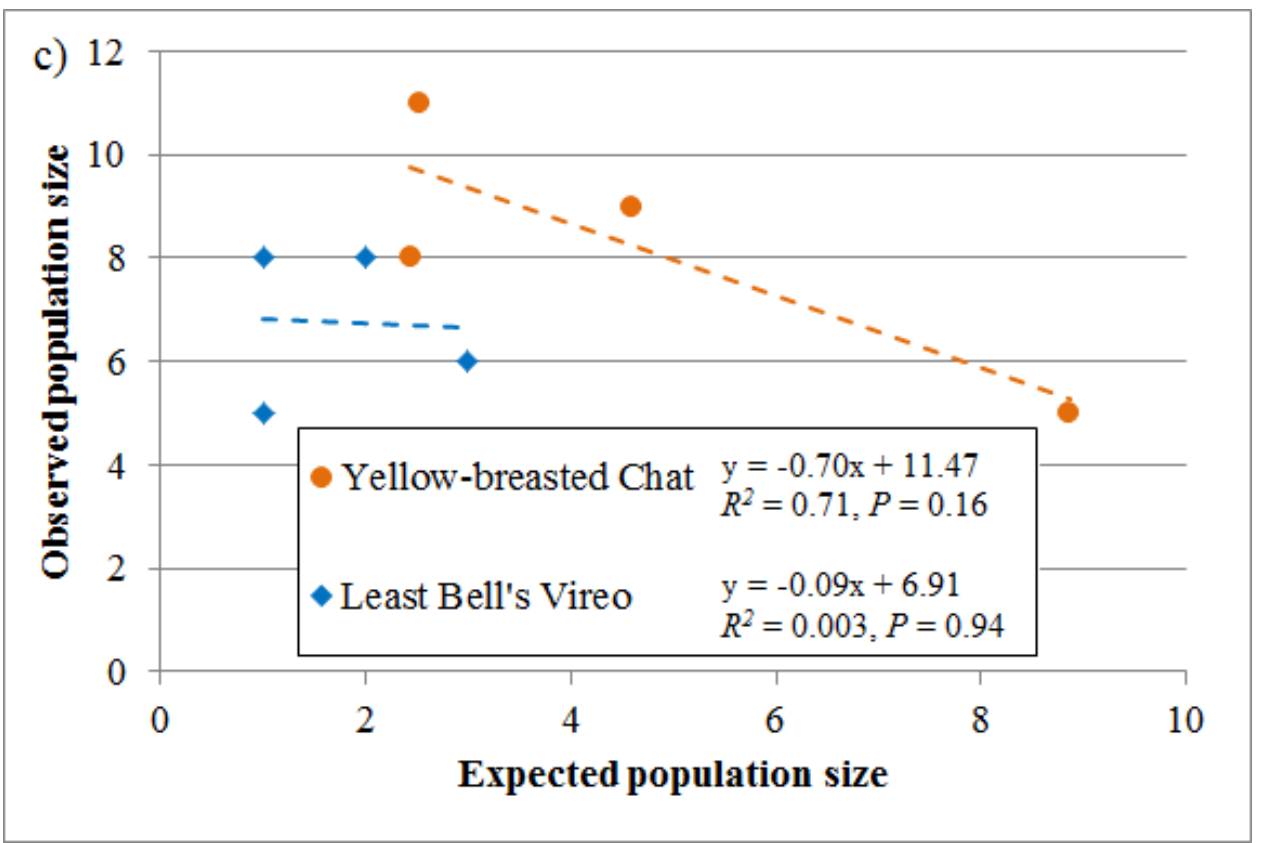

Figure B5.-Continued. 
Table B13. Least Bell's Vireo individuals captured (newly banded and recaptured) at Naval Outlying Landing Field, Imperial Beach, 2009-13.

[Color combination: Msi, metal silver numbered federal band; pupu, metal purple band; BKBK, plastic black; BKLP, plastic black/light pink split; BYST, plastic black/yellow striped; DPDP, plastic dark pink; DPWH, plastic dark pink/white split, LPBK, plastic light pink/black split; LPLP, plastic light pink; PUPU, plastic purple; PUWH, plastic purple/white split; PUYE, plastic purple/yellow split; WHDP, plastic white/dark pink split; WHPU, plastic white/purple split; WHWH; plastic white, YEPU, plastic yellow/purple split; YEYE, plastic yellow. Age: HY, hatching-year; AHY, after hatching-year; SY, second-year; ASY, after second-year]

\begin{tabular}{|c|c|c|c|c|c|}
\hline \multirow[b]{2}{*}{ Band number } & \multicolumn{2}{|c|}{ Color combination } & \multirow[b]{2}{*}{ Age } & \multirow[b]{2}{*}{ Sex } & \multirow{2}{*}{$\begin{array}{c}\text { Initial capture } \\
\text { date for the } \\
\text { year }\end{array}$} \\
\hline & Left leg & Right leg & & & \\
\hline $2400-84993$ & -- & Msi & AHY & Female & 05-05-09 \\
\hline $2400-84825$ & -- & PUPU/Msi & AHY & Female & 05-11-09 \\
\hline $2400-84810$ & -- & Msi & AHY & Male & 05-11-09 \\
\hline $2400-84811$ & -- & Msi & AHY & Male & 05-11-09 \\
\hline $2400-85000$ & -- & Msi & AHY & Female & 05-11-09 \\
\hline $2400-84873$ & -- & WHWH/Msi & AHY & Female & 06-01-09 \\
\hline 1920-24080 & -- & YEYE/Msi & HY & Unknown & 08-04-09 \\
\hline $2400-84825^{1}$ & -- & PUPU/Msi & ASY & Female & $05-06-10$ \\
\hline $1920-24427$ & -- & DPDP/Msi & SY & Female & $05-13-10$ \\
\hline $1920-24216$ & -- & BKBK/Msi & HY & Unknown & $06-17-10$ \\
\hline $1920-24217$ & -- & LPLP/Msi & HY & Unknown & $06-17-10$ \\
\hline $1920-24227$ & YEYE/Msi & -- & SY & Female & $06-17-10$ \\
\hline $1920-24233$ & PUPU/Msi & -- & SY & Male & $06-25-10$ \\
\hline $1920-24234$ & LPLP/Msi & -- & HY & Unknown & $06-25-10$ \\
\hline $1920-24236$ & BKBK/Msi & -- & HY & Unknown & $06-25-10$ \\
\hline $2400-84873^{1}$ & -- & WHWH/Msi & ASY & Female & $06-25-10$ \\
\hline $1920-24255$ & DPDP/Msi & -- & HY & Unknown & $07-07-10$ \\
\hline $2400-84810^{1}$ & LPLP & Msi & ASY & Male & $07-07-10$ \\
\hline $1920-24271$ & WHWH/Msi & -- & HY & Unknown & $07-19-10$ \\
\hline 1920-24288 & DPDP & Msi & HY & Unknown & 07-29-10 \\
\hline $2590-60113$ & Msi & DPDP & SY & Unknown & $05-02-11$ \\
\hline $2590-60125$ & YEYE & Msi & ASY & Male & 05-11-11 \\
\hline $2590-60132$ & BKBK & Msi & HY & Unknown & $05-11-11$ \\
\hline $2590-60141$ & Msi & PUPU & SY & Unknown & $05-25-11$ \\
\hline $2590-60143$ & PUPU & Msi & SY & Female & $05-25-11$ \\
\hline $2590-60156$ & PUWH/Msi & -- & HY & Unknown & 06-15-11 \\
\hline $2590-60178$ & -- & PUWH/Msi & HY & Unknown & 06-24-11 \\
\hline 2590-60184 & WHPU/Msi & -- & SY & Female & $06-24-11$ \\
\hline $2250-48401$ & YEPU/Msi & -- & HY & Unknown & $07-15-11$ \\
\hline $2250-48409$ & -- & WHPU/Msi & ASY & Female & $07-15-11$ \\
\hline $2250-48413$ & BKLP/Msi & -- & HY & Unknown & $07-15-11$ \\
\hline $2590-60200$ & LPBK/Msi & -- & $\mathrm{AHY}$ & Unknown & $07-15-11$ \\
\hline $2250-48416$ & PUYE/Msi & -- & HY & Unknown & $07-27-11$ \\
\hline $2250-48421$ & -- & LPBK/Msi & HY & Unknown & 08-05-11 \\
\hline $2250-48424$ & Msi & WHWH & HY & Unknown & $08-05-11$ \\
\hline $2250-48426$ & -- & YEPU/Msi & HY & Unknown & $08-05-11$ \\
\hline
\end{tabular}




\begin{tabular}{|c|c|c|c|c|c|}
\hline \multirow[b]{2}{*}{ Band number } & \multicolumn{2}{|c|}{ Color combination } & \multirow[b]{2}{*}{ Age } & \multirow[b]{2}{*}{ Sex } & \multirow{2}{*}{$\begin{array}{c}\text { Initial capture } \\
\text { date for the } \\
\text { year }\end{array}$} \\
\hline & Left leg & Right leg & & & \\
\hline $2400-84810^{1}$ & LPLP & Msi & ASY & Male & $08-05-11$ \\
\hline $2400-84810^{1}$ & LPLP & Msi & ASY & Male & 04-05-12 \\
\hline 2690-94335 & Msi & YEYE & AHY & Female & $04-05-12$ \\
\hline 2690-94355 & -- & WHWH/Msi & SY & Male & $04-26-12$ \\
\hline $2690-94230$ & PUPU/pupu & Msi & AHY & Unknown & 06-07-12 \\
\hline $2690-94260$ & WHWH/Msi & pupu & AHY & Female & 06-14-12 \\
\hline $2400-84810^{1}$ & LPLP & Msi & ASY & Male & 04-04-13 \\
\hline $2700-03654$ & -- & BYST/Msi & AHY & Female & 04-11-13 \\
\hline $2690-94355^{1}$ & -- & WHWH/Msi & ASY & Male & $05-02-13$ \\
\hline $2710-29411$ & -- & DPWH/Msi & AHY & Female & $05-16-13$ \\
\hline $2710-29454$ & -- & WHDP/Msi & HY & Unknown & 06-13-13 \\
\hline $2710-29460$ & pupu & PUPU/Msi & AHY & Unknown & $06-20-13$ \\
\hline $2710-29467$ & -- & BKLP/Msi & $\mathrm{AHY}$ & Unknown & $06-20-13$ \\
\hline $2710-29468$ & -- & PUYE/Msi & AHY & Unknown & $06-20-13$ \\
\hline $2710-29478$ & Msi & LPLP & HY & Unknown & $07-08-13$ \\
\hline $2710-29480$ & pupu & PUWH/Msi & HY & Unknown & $07-08-13$ \\
\hline $2710-29481$ & pupu & WHPU/Msi & HY & Unknown & $07-08-13$ \\
\hline 2710-29506 & Msi & BKBK & AHY & Unknown & 08-01-13 \\
\hline
\end{tabular}

${ }^{1}$ Recaptured individual banded previously at NOLF. 
This page left intentionally blank 
Publishing support provided by the U.S. Geological Survey

Science Publishing Network, Tacoma Publishing Service Center

For more information concerning the research in this report, contact the Director, Western Ecological Research Center

U.S. Geological Survey

3020 State University Drive East

Sacramento, California 95819

http://werc.usgs.gov/ 


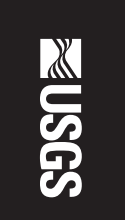

5

言

웋

3

흥.

흐.

ㄴ.

꿓

흘. 